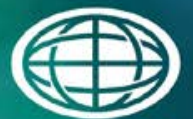

Savannah River

National Laboratory ${ }^{m}$

OPERATED BY SAVANNAH RIVER NUCLEAR SOLUTIONS

\title{
Consideration of Liners and Covers in Performance Assessments
}

Mark A. Phifer, SRNL

Roger R. Seitz, SRNL

Linda C. Suttora, DOE-EM

September 2014

SRNL-STI-2014-00409, Revision 0 
SRNL-STI-2014-00409

Revision 0

\section{DISCLAIMER}

This work was prepared under an agreement with and funded by the U.S. Government. Neither the U.S. Government or its employees, nor any of its contractors, subcontractors or their employees, makes any express or implied:

1. warranty or assumes any legal liability for the accuracy, completeness, or for the use or results of such use of any information, product, or process disclosed; or

2. representation that such use or results of such use would not infringe privately owned rights; or

3. endorsement or recommendation of any specifically identified commercial product, process, or service.

Any views and opinions of authors expressed in this work do not necessarily state or reflect those of the United States Government, or its contractors, or subcontractors.

\section{Printed in the United States of America \\ Prepared for U.S. Department of Energy}


Keywords: Liners

Covers

Retention: Permanent

\section{Consideration of Liners and Covers in Performance Assessments}

Mark A. Phifer, SRNL

Roger R. Seitz, SRNL

Linda C. Suttora, DOE-EM

September 2014

Prepared for the U.S. Department of Energy under contract number DE-AC09-08SR22470.

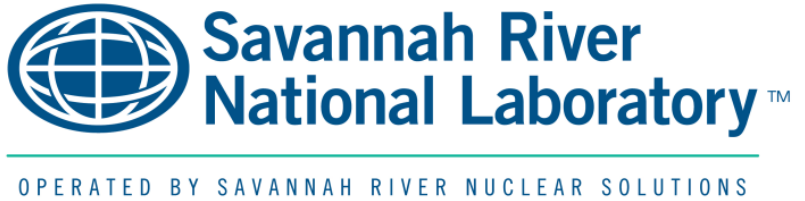




\section{REVIEWS AND APPROVALS}

\section{AUTHORS:}

Mark A. Phifer, Radiological Performance Assessment, SRNL

Roger R. Seitz, Radiological Performance Assessment, SRNL

Linda C. Suttora, Office of Compliance, Office of Environmental Management, DOE $\quad$ Date

Michael G. Serrato, Environmental Restoration Technologies, SRNL

Date

APPROVAL:

David A. Crowley, Manager

Date

Radiological Performance Assessment, SRNL

Robert S. Aylward, Manager

Date

Environmental Restoration Technologies, SRNL 


\section{ACKNOWLEDGEMENTS}

The United States Department of Energy - Environmental Management (USDOE-EM) Office of Site Restoration has formed a working group to foster improved communication and sharing of information for personnel associated with Comprehensive Environmental Response, Compensation, and Liability Act and Resource Conservation and Recovery Act disposal cells across the DOE complex. The working group provides a forum to work towards more consistent assumptions, as appropriate, for technical and policy considerations related to performance and risk assessments in support of a Record of Decision and Disposal Authorization Statement. This report was prepared as part of the activities of that working group, and thus, includes input, suggestions, and comments from numerous people that have participated in that working group. Although the final contents are the responsibility of the authors, this feedback from the broader working group has substantially improved the content of the document and is greatly appreciated. This report is intended to serve as a resource for sources of information that can be consulted by people working on assessments involving long-term performance of disposal systems involving covers and/or liners, but should not be interpreted as official policy. 


\section{EXECUTIVE SUMMARY}

On-site disposal cells are in use and being considered at several United States Department of Energy (USDOE) sites as the final disposition for large amounts of waste associated with cleanup of contaminated areas and facilities. These disposal cells are typically regulated by States and/or the U.S. Environmental Protection Agency under the Comprehensive Environmental Response, Compensation, and Liability Act (CERCLA) in addition to having to comply with requirements in DOE Order 435.1, Radioactive Waste Management due to the radioactive waste. The USDOE-Environmental Management Office of Site Restoration formed a working group to foster improved communication and sharing of information for personnel associated with these CERCLA disposal cells and work towards more consistent assumptions, as appropriate, for technical and policy considerations related to CERCLA risk assessments and DOE Order 435.1 performance assessments in support of a Record of Decision and Disposal Authorization Statement, respectively. One of the issues considered by the working group, which is addressed in this report, was how to appropriately consider the performance of covers and liners/leachate collections systems in the context of a DOE Order 435.1 performance assessment (PA). This same information may be appropriate for consideration within CERCLA risk assessments for these facilities.

These OSDCs are generally developed to meet hazardous waste (HW) disposal design standards under the Resource Conservation and Recovery Act (RCRA) as well as the DOE Order 435.1 performance based standards for disposal of radioactive waste. To meet the standards for HW, the facilities typically include engineered covers and liner/leachate collection systems. Thus, when considering such facilities in the context of a DOE Order 435.1 PA, there is a need to address the evolution of performance of covers and liner/leachate collection systems in the context of meeting a performance standard considering time frames of 1,000 years for compliance and potentially thousands of years based on the wastes to test the robustness of the system. Experience has shown that there are a range of expectations and perspectives from the different regulators involved at different sites when reviewing assumptions related to cover and liner/leachate collection system performance. However for HW disposal alone under RCRA the design standards are typically considered sufficient by the regulators without a requirement to assess long-term performance thus avoiding the need to consider the details addressed in this report.

This report provides suggestions for a general approach to address covers and liners/leachate collection systems in a DOE Order 435.1 PA and how to integrate assessments with defense-in-depth considerations such as design, operations, and waste acceptance criteria to address uncertainties. The emphasis is on water balances and management in such assessments. Specific information and references are provided for details needed to address the evolution of individual components of cover and liner/leachate collection systems. This information was then synthesized into suggestions for best practices for cover and liner system design and examples of approaches to address the performance of covers and liners as part of a performance assessment of the disposal system. Numerous references are provided for sources of information to help describe the basis for performance of individual components of cover and liner systems. 


\section{TABLE OF CONTENTS}

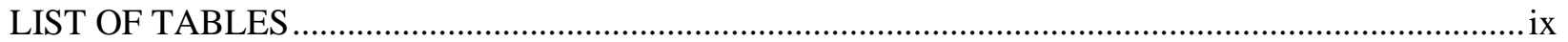

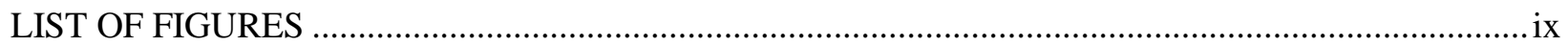

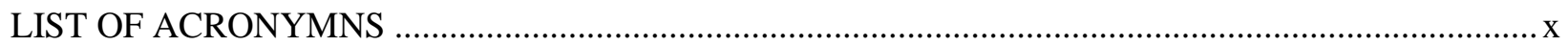

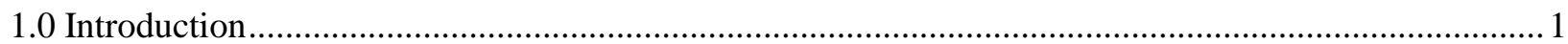

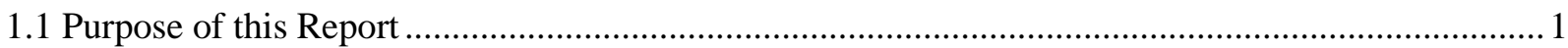

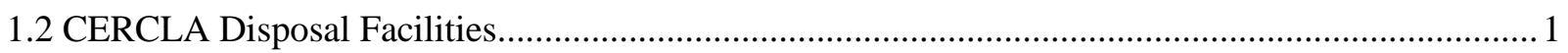

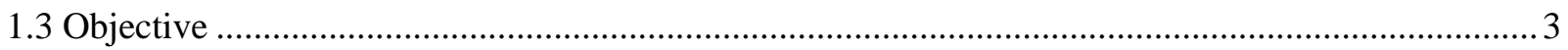

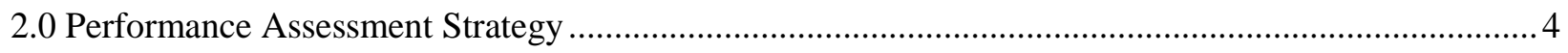

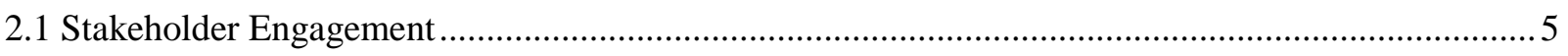

2.2 Timing Considerations for Covers, Liners and System Performance ............................................. 6

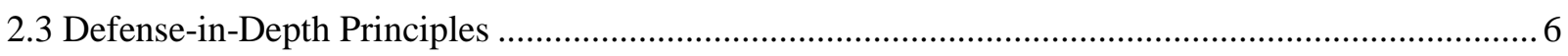

3.0 General Approach to Consider Covers and Liners ......................................................................... 8

3.1 Step 1: Develop Initial Representation of Total Disposal System ................................................. 9

3.2 Step 2: Develop Initial Conceptual Models for Each Layer.............................................................. 9

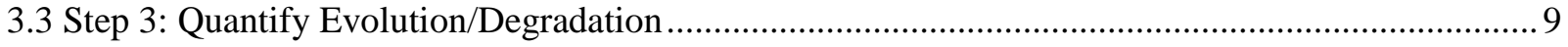

3.4 Step 4: Identify Total System Scenarios to be Considered ............................................................10

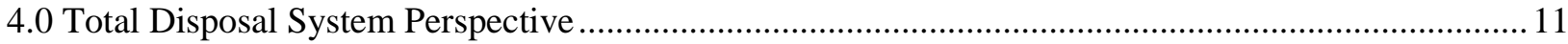

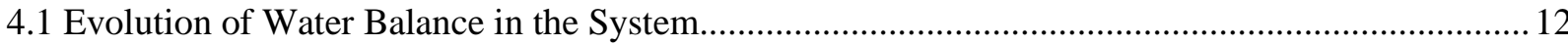

5.0 Conceptual Description of the Disposal System................................................................................. 15

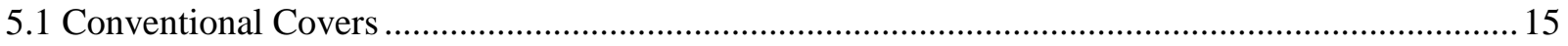

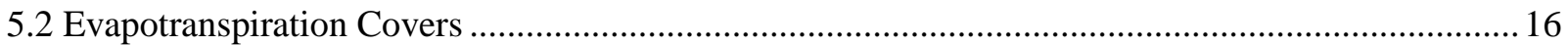

5.3 Liner and Leachate Collection Systems …............................................................................... 17

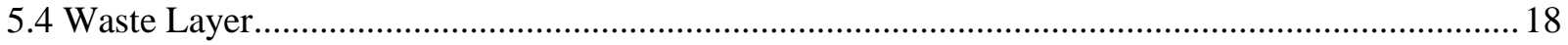

6.0 Functional Roles of Cover System Components ............................................................................... 19

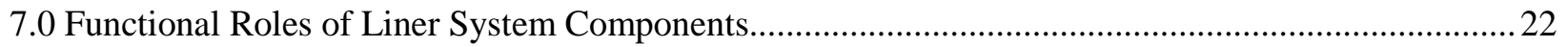

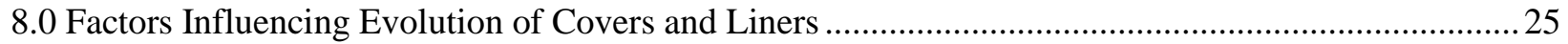

9.0 Technical Information about Long-Term Evolution of Covers and Liners .........................................3

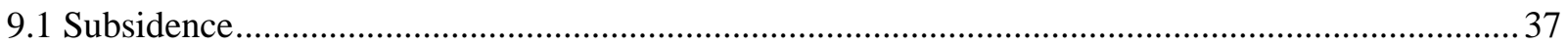

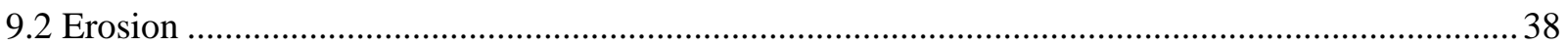

9.3 Cover Drainage Layer and Liner Leachate Collection System Pluggage ...................................... 39

9.4 HDPE Geomembrane Degradation (Antioxidant Depletion, Thermal Oxidation, and Tensile Stress

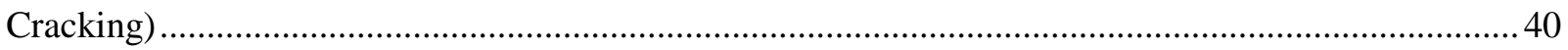

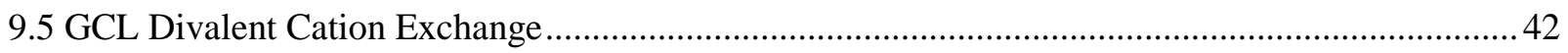


9.6 GCL and CCL Desiccation, Root Penetration, and Burrowing Animals ....................................... 44

9.7 Leachate and Chemical Compatibility with HDPE Geomembranes and GCLs.............................46

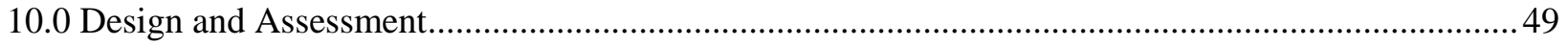

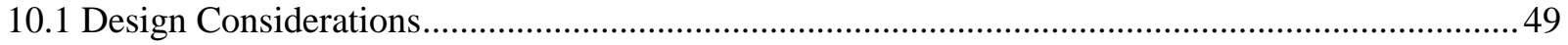

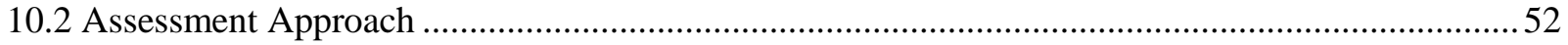

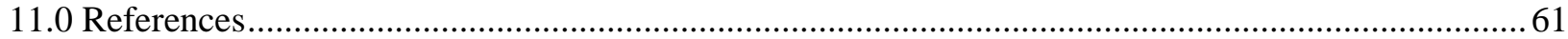

Appendix A . Original White Paper on Consideration of Long-Term Performance of Barriers (Covers and

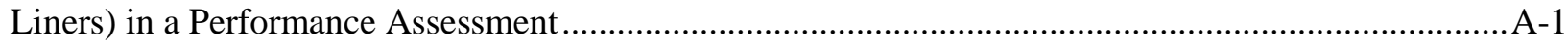

Appendix B . High Energy Irradiation Degradation of HDPE Geomembranes ................................... B-1 


\section{LIST OF TABLES}

Table 4-1. Summary of Water Balance Considerations at Different Times. ............................................ 14

Table 6-1. Functional Roles of Typical Cover Components.................................................................. 20

Table 7-1. Functional Roles of Typical Double Liner Layers. ............................................................... 23

Table 8-1. Potential Cover Layer Degradation Mechanisms................................................................... 27

Table 8-2. Potential Liner Materials Degradation Mechanisms. …............................................................ 32

Table 9-1. Koerner et al. (2011) Lifetime Prediction for Non-Exposed HDPE Geomembranes............... 40

Table 9-2. Rowe et al. (2009) Lifetime Prediction for Non-Exposed HDPE Geomembranes Immersed in Landfill Leachate.

Table 9-3. Needham et al. (2004) and Needham et al. (2006) Antioxidant Depletion Period Prediction. 41

Table 9-4. GCL Average Saturated Hydraulic Conductivity (Jo et al. 2005).......................................... 43

Table 10-1. DOE Low-Level Waste Disposal Facilities - Cover and Liner Overview............................. 55

Table B-1. Dose Rate Impact on HDPE Ultimate Strength and Elongation Half-Value Dose in Air

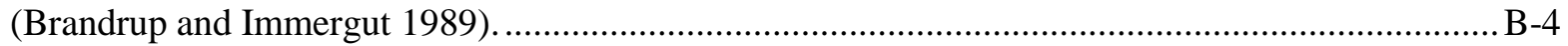

\section{LIST OF FIGURES}

Figure 4-1. High-Level Perspective of Water Balances........................................................................... 11

Figure 4-2. Example of the Evolution of Water Balance Over Time (Arrows Denote Water Movement)

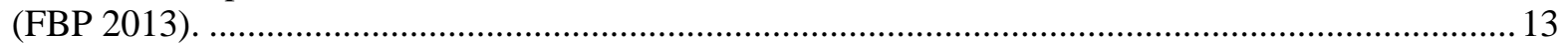

Figure 5-1. Conventional LLW Disposal Facility Cover (Generally in Cases with Precipitation > ET) (FBP 2013).

Figure 5-2. ET Cover Designs (EPA 2011) (ET > Precipitation). Left Figure is a "Monolithic" ET Cover and Right Figure is a "Capillary Barrier” ET Cover. .......................................................................... 17

Figure 5-3. Typical Double Liner System (FBP 2013) and the Weldon Spring Disposal Cell. ................ 18

Figure B-1. Dose Rate Impact on HDPE Ultimate Strength and Elongation Half-Value Dose in Air (Brandrup and Immergut 1989).................................................................................................... 
SRNL-STI-2014-00409

Revision 0

\section{LIST OF ACRONYMNS}

\begin{tabular}{|c|c|}
\hline ACM & asbestos contaminated materials \\
\hline ARAR & applicable or relevant and appropriate requirements \\
\hline CC & compacted clay \\
\hline CCL & compacted clay layers \\
\hline CERCLA & Comprehensive Environmental Response, Compensation, and Liability Act \\
\hline DAS & Disposal Authorization Statement \\
\hline D\&D & deactivation and decommissioning \\
\hline DL & drainage layer \\
\hline DOE & Department of Energy \\
\hline ELLWF & E-Area Low-Level Waste Facility \\
\hline EMWMF & Environmental Management Waste Management Facility \\
\hline ERDF & Environmental Restoration Disposal Facility \\
\hline EPA & Environmental Protection Agency \\
\hline ET & evapotranspiration \\
\hline FBP & Fluor-B\&W Portsmouth \\
\hline FTF & F-Area Tank Farm \\
\hline GCL & geosynthetic clay liner \\
\hline GML & geomembrane liner \\
\hline GSI & Geosynthetic Institute \\
\hline HDPE & high density polyethylene \\
\hline HELP & Hydrologic Evaluation of Landfill Performance \\
\hline HTF & H-Area Tank Farm \\
\hline HW & hazardous waste \\
\hline ICDF & INL CERCLA Disposal Facility \\
\hline IDF & Integrated Disposal Facility \\
\hline INEEL & Idaho National Engineering and Environmental Laboratory \\
\hline INL & Idaho National Laboratory \\
\hline LANL & Los Alamos National Laboratory \\
\hline LFRG & Low-Level Waste Disposal Facility Federal Review Group \\
\hline LLW & Low-level waste \\
\hline LMDPE & Linear Medium Density Polyethylene \\
\hline MW & mixed waste \\
\hline MUSLE & Modified Universal Soil Loss Equation \\
\hline NCRP & National Council on Radiation Protection and Measurements \\
\hline NRC & Nuclear Regulatory Commission \\
\hline NTS & Nevada Test Site \\
\hline ORP & Office of River Protection \\
\hline OSDC & On-site Disposal Cells \\
\hline PA & Performance Assessment \\
\hline PCB & polychlorinated biphenyls \\
\hline PMP & Probable Maximum Precipitation \\
\hline QA & Quality Assurance \\
\hline RCRA & Resource Conservation and Recovery Act \\
\hline RH-LLW & Remote-Handled Low-Level \\
\hline ROD & Record of Decision \\
\hline RUSLE2 & Revised Universal Soil Loss Equation, Version 2 \\
\hline RWMC & Radioactive Waste Management Complex \\
\hline
\end{tabular}




$\begin{array}{ll}\text { RWMS } & \text { Radioactive Waste Management Site } \\ \text { SDF } & \text { Saltstone Disposal Facility } \\ \text { SRNL } & \text { Savannah River National Laboratory } \\ \text { SRR } & \text { Savannah River Remediation } \\ \text { SRS } & \text { Savannah River Site } \\ \text { TA } & \text { Technical Area } \\ \text { TBC } & \text { to-be-considered } \\ \text { TSCA } & \text { Toxic Substances Control Act } \\ \text { UMTRA } & \text { Uranium Mill Tailings Remedial Action } \\ \text { USDOE-EM } & \text { United States Department of Energy - Environmental Management } \\ \text { USLE } & \text { Universal Soil Loss Equation } \\ \text { UV } & \text { Ultraviolet } \\ \text { WCH } & \text { Washington Closure Hanford } \\ \text { WCS } & \text { Waste Control Specialists } \\ \text { WSRC } & \text { Washington Savannah River Company }\end{array}$


SRNL-STI-2014-00409

Revision 0

Intentionally Blank 


\subsection{Introduction}

The Department of Energy (DOE) manages numerous waste disposal facilities, for example:

- Uranium Mill Tailings Remedial Action (UMTRA) facilities,

- Low-level waste (LLW) disposal facilities,

- Comprehensive Environmental Response, Compensation, and Liability Act (CERCLA) disposal facilities, and

- Solid waste (Subtitle D) facilities.

All of these facilities have or will have some type of cover over the buried waste. For some facilities the covers will include high density polyethylene (HDPE) liners, geosynthetic clay layers (GCL), and/or compacted clay layers (CCL). Other covers are based on more simplified designs. Regulations specific to the waste type being disposed and local site conditions drive the design requirements of a particular facility. In the cases of LLW disposal under DOE Order 435.1, there are no prescribed cover design requirements beyond being compatible with the waste and based on DOE Order 435.1 performance assessments. Engineered structures (vaults) and waste forms can also be used to provide additional barriers. Liner and leachate collection systems are also required to be included in many facilities that are typically engineered to meet prescriptive Resource Conservation and Recovery Act (RCRA) Subtitle C requirements specific to disposal of wastes containing hazardous constituents. Liner and leachate collection systems are not specifically required for DOE LLW that is deemed to not meet the definition of mixed waste. There can be substantial uncertainties associated with the effective life of these design features, which introduces challenges when trying to assess the long-term performance of disposal facilities.

\subsection{Purpose of this Report}

This report is intended to serve as a reference for information related to developing a logical approach to specify the basis for the design and assessment of cover and liners that are considered in DOE Order 435.1 PAs (it may also be applicable to CERCLA risk assessments of these facilities) with an emphasis on water balances and management rather than transport of contaminants. Although this report provides a number of ideas and suggestions that can be considered, it is not intended to reflect a recommended or approved approach that should be used. Each assessment will need be reviewed by the appropriate regulator (e.g., the Low-Level Waste Disposal Facility Federal Review Group (LFRG) for DOE, State regulatory authority, Nuclear Regulatory Commission (NRC) or Environmental Protection Agency (EPA)), and the approach used will need to meet the expectations of those reviewers. A general suggestion is to include the regulators early in the design and assessment process to address specific concerns prior to the final reviews. The information in this report is intended to help with such discussions and provide information to help reach agreement on an acceptable approach.

\subsection{CERCLA Disposal Facilities}

This report focuses on On-site Disposal Cells (OSDCs) for LLW and mixed waste (MW) that have been developed and are planned at DOE sites as part of CERCLA and other remedial actions. Wastes to be disposed include materials resulting from the deactivation and decommissioning (D\&D) of surplus facilities and remediation of buried waste sites and/or contaminated environmental media such as soils and sediments. Such facilities must meet the threshold requirements of CERCLA and/or other applicable external regulations as well as DOE Order 435.1, Radioactive Waste Management. This creates a complex regulatory situation, where there are three potential regulators that must review the assessment 
of facility performance (DOE, States and EPA). All CERCLA response actions, including the design, construction, operation, and construction of on-site disposal facilities must meet two threshold criteria:

1. Must be protective of human health and the environment - typically measured under CERCLA as attaining a risk range of $1 \mathrm{E}-04$ to $1 \mathrm{E}-06$, and a hazard index $<1$ and

2. Must meet applicable or relevant and appropriate requirements (ARARs). ARARs are chemicalspecific, action-specific, and location-specific Federal, State, and local requirements necessary to safely and effectively apply to the CERCLA response action in order to meet the remedial action objectives.

The ARARs incorporated into CERCLA decision documents (i.e., records of decision) generally lead to a need for the inclusion of liners and leachate collection systems below the waste in addition to conventional covers. ARARs for CERCLA cells constructed to date, and expected in the future include U.S. EPA (or State equivalent) requirements for disposal of hazardous waste (HW) defined in the RCRA Subtitle C requirements (40 CFR 264.301) and Toxic Substances Control Act of 1976 (TSCA) waste disposal requirements (40 CFR 761.75). Typical TSCA waste includes asbestos contaminated materials (ACM) and polychlorinated biphenyls (PCB). The typical RCRA approach for a disposal facility uses a design standard for disposal cells that essentially removes the requirement to assess long-term performance and avoids the need to consider the details addressed in this report. Thus, the concept of conducting assessments for long-term performance may not be a familiar to people that have only addressed disposal in the RCRA context.

DOE Order 435.1 requires that a PA be developed and maintained for a LLW disposal facility or a crosswalk be provided to demonstrate that the expectations for a PA have been addressed ${ }^{1}$. PA (after NCRP 2005) is an iterative process involving site-specific, prospective modeling evaluations with two primary objectives:

- to determine whether reasonable expectation of compliance with quantitative performance objectives can be demonstrated, and,

- to identify critical data, facility design, and model development needs for defensible, costeffective, and risk-informed decisions concerning both management of the facility and minimization of releases from the facility to the extent practical during the performance period.

This definition emphasizes that, because of the need to model the system for hundreds or thousands of years, the PA is a process that focuses primarily on a decision about compliance with regulatory requirements, rather than the much more difficult challenge of predicting actual outcomes of waste disposal (i.e., actual radiological impacts on the public and the environment). This perspective of demonstrating that the peak impacts will be less than a standard rather than predicting an impact has a significant influence on how a PA is conducted in the presence of significant uncertainties, such as those associated with the long term performance of cover and liner systems.

The PA must demonstrate compliance with performance objectives for a time frame of 1,000 years following facility closure and also consider longer-term peak impacts in the context of risk-informed decision-making (DOE Order 435.1, Radioactive Waste Management). Performance objectives include all pathways dose to a resident near the facility (e.g., air, groundwater, irrigated vegetables, etc.), air pathway dose, radon release, and water resources protection. Assumptions regarding the performance of covers and liners can have a significant influence on the timing and magnitude of releases from the disposal facility and the ability to meet these requirements. There is also a performance measure to assess

\footnotetext{
${ }^{1}$ This paper is prepared using the assumption that a PA is conducted, but the general principles are expected to apply if the PA requirements are met using documentation from a risk assessment or other assessment.
} 
the potential impacts to someone that may inadvertently intrude into the facility after a loss of institutional control. Human intrusion is generally assumed to potentially occur as the result of a loss of institutional controls. Two types of scenarios are generally considered: drilling or basement construction. Cover design can play a role in mitigating or delaying the impacts from inadvertent human intrusion. Basement construction can be mitigated by maintaining sufficient thickness of cover (generally 3-5 $\mathrm{m}$ ) of clean material above the waste. Drilling is more difficult to deter and depends on site specific drilling practices.

Cover design can also influence the likelihood and significance of biotic intrusion that can influence infiltration into the facility. Thus, covers need to be considered in the context of limiting water flow into the facility as well as potentially providing a barrier to intrusion. The emphasis of this report is on water and leachate considerations, but factors that can influence inadvertent human intrusion are also briefly described.

It is important to maintain perspective that assessment results alone do not make the case for a disposal facility. This report advocates a multi-faceted approach of engaging stakeholders and using a combination of the assessment, design and operational concepts, and waste acceptance criteria to make the case for a disposal concept. Design, operational practices and waste acceptance criteria can be used to help address uncertainties that are difficult to completely address in the assessment calculations. For example, effective Quality Assurance (QA) during compaction has proven to be a valuable confidence builder for assumptions regarding subsidence. Other activities, such as monitoring and institutional controls are also used to provide defense-in-depth and build confidence in the overall safety of the disposal system.

\subsection{Objective}

Recent efforts to develop PAs for lined disposal facilities have highlighted the need for a more common approach to address the performance and evolution ${ }^{2}$ of cover and liner systems. There can be a range of expectations and perspectives regarding approaches to address long-term performance of cover and liner systems from different regulators. Additionally the extent to which the evolution of cover and liner systems is taken into account and justified within PAs depends upon the extent to which credit must be taken for the performance of the cover and liner system within the PA. The need to justify and take into account cover and liner system evolution generally diminishes as the cover and liner system become a defense-in-depth component for which little credit is given within the PA relative to reducing contaminant release out of the disposal facility (a caveat must be made for potential counter-intuitive results discussed in Section 2.2, Timing Considerations for Covers, Liners and System Performance below).

This document provides suggestions for a logical approach that can be considered to develop the basis for assumptions for these assessments and how to integrate assessments with defense-in-depth considerations such as design, operations and waste acceptance criteria to address uncertainties. Specific information and references are provided for details needed to address the evolution of individual components of cover and liner systems. This information is then synthesized into suggestions for cover and liner system design and examples of approaches to address the performance of covers and liners as part of a PA of the disposal system. Numerous references are provided for sources of information to help describe the basis for performance of individual components of cover and liner systems.

\footnotetext{
${ }^{2}$ Terms such as “evolution” and "alteration” were discussed at the NRC Workshop on Engineered Barrier Performance to reflect that over time there are processes that can degrade or improve the performance of cover and liner components (Nicholson and Arlt (2011)). "Evolution” is used generally used in this paper to address potential degradation or improvement of performance over time.
} 


\subsection{Performance Assessment Strategy}

Each facility and disposal site will have unique characteristics that influence how a PA is implemented. Long-term performance of covers and liners involves significant uncertainty that needs to be managed differently in the specific context of each disposal facility. Effective management of uncertainties involves integration of design, assessment, waste acceptance criteria, stakeholder engagement, etc. Stakeholder interests and the hazards posed by the waste to be disposed have an important influence on the approach and focus of efforts for a given facility. These considerations lead to the need for a process or strategy to efficiently implement the assessments rather than simply laying out a computational approach that will be applicable for all cases. It is also generally suggested to avoid the use of worst case type assumptions or, if such assumptions are used, to do so cautiously and clearly document those assumptions including a discussion of expected performance. The intent is to place the assumptions in perspective.

Given that the goal is to demonstrate that results are below a regulatory performance objective rather than predicting exactly what will occur, a graded and iterative approach is generally applied to implement a PA. Another way of thinking of the graded approach is an emphasis on determining what you need and don't need to take credit for in the context of efficiently and defensibly demonstrating compliance. Given the uncertainties involved, there can be a significant burden to take credit for long-term performance of individual components of cover and liner systems. To this end, this report provides a strategy that focuses on describing and understanding the behavior of the total system, especially focused on determining those aspects of the system that have a significant influence on performance. Detailed information is provided to assist with considering long-term evolution of individual components in those cases where it is deemed important to address performance in greater detail.

The graded approach involves starting with initial screening analyses to identify unimportant aspects and to focus efforts on the aspects that have the most significant influence on the results. The first step is development of an initial conceptualization of the total disposal system based on available information. The total system includes covers, waste and backfill, liner systems, and the natural environment. The waste can also include barriers such as the waste form or containers that may need to be considered. The importance of maintaining a total systems performance perspective and being able to understand and describe the interrelationship among the different layers is reinforced throughout this report. As the analysis evolves, the initial conceptual model is refined in areas that are determined based on initial modeling to have a significant impact on the ability to meet the performance requirements. This focused refinement is a key for the graded and iterative approach.

Implementation of the graded and iterative approach is driven to a large extent by the source term in the facility. The source term represents the inherent risk associated with what is placed in a disposal facility and the level of effort required for a PA is typically correlated with the level of risk associated with the waste being disposed and the local site conditions. Initial screening calculations will typically focus on narrowing the list of waste forms and radionuclides that need to be addressed in detail. Relatively simple screening calculations can generally be used to reduce the scope of the modeling effort to focus on a short list of longer-lived radionuclides prior to detailed consideration of the role of engineered features. If the concentrations of longer-lived radionuclides are relatively low and the site conditions are favorable, a PA may be able to be completed using relatively simple approaches that only require consideration of shortterm performance of engineered features that can be easily defended. For example, in some cases, it can be assumed that engineered features fail at the end of active institutional controls and the performance objectives can be met. However, Section 2.2, Timing Considerations for Covers, Liners and System Performance, identifies a caution about the potential to miss peak impacts by not taking credit for the expected lifetime for a liner system. This is an example of the need to describe the expected performance 
when making simplifying assumptions and to consider whether or not the assumption can be defended as being conservative relative to expected performance.

In cases where the concentrations of longer-lived radionuclides may be higher and/or site conditions are not as favorable, it can become necessary to add detail to address the longer-term evolution of cover and liner systems and waste forms/containers. The focus of the more detailed assessment then transitions to consideration of how engineered features impact: 1) the timing of when releases of the longer-lived radionuclides can occur, and 2) the rate at which releases can occur. The intent of the PA process in this case is to identify and focus efforts on those features that have a strong influence on performance. This report provides information to support more detailed consideration of performance of individual components in cover and liner systems. While the presence of longer-lived radionuclides may drive the need to address the longer-term evolution of the cover and liner systems, highly mobile, short-lived radionuclides may also be a significant consideration relative to the projected compliance with the standards particularly relative to the initial design.

Experience has shown that assessments cannot always adequately resolve all of the uncertainties associated with long term performance of a disposal facility. As discussed above, in order to address areas where the uncertainties are difficult to resolve using more in-depth assessment, the assessment strategy can work in tandem with the use of defense-in-depth, including operations and design principles to mitigate potential issues and waste acceptance criteria to limit what can be disposed. Monitoring and institutional controls can also be highlighted as features to help build confidence. The approach described in this report also involves suggestions for presenting information to stakeholders to explain how the disposal system functions and the multiple layers of defense to provide the level of protection that is needed.

\subsection{Stakeholder Engagement}

The approach for addressing long-term performance of cover and liner systems in a PA needs to be determined on a case-by-case basis through negotiation and/or technical reviews with the appropriate regulators, typically DOE (LFRG), EPA and the State regulator. This is appropriate because each liner and cover system is designed and assessed individually in the context of the climate, hydrogeology, waste and current technical standards at the time of construction. Early discussions with the regulator and other stakeholders should seek to understand specific concerns and interests relative to long-term performance. The role of the time of compliance and the level of regulator interest relative to the long-term performance of covers and liners should be established early. This will help to prioritize key features and concerns and will have a significant influence on the approach that is adopted.

Inevitably, there will be comparisons between assumptions being made at one facility relative to assumptions made at other facilities across the DOE complex. This is the reason for the need to document the assumptions made for the purposes of a PA versus what would actually be expected (e.g., identify and clearly document assumptions that are intended to over-predict releases). While reference to the negotiated credit applied to other facilities may be made, the inherent uncertainties associated with site and facility specific effects on long-term performance must be recognized. Likewise, it must be realized that the knowledge base to support assumptions regarding liner and cover performance increases with time and that different regulators approach the issue with different interests and concerns. Thus, although assumptions made at other sites may provide a point of comparison, often there are site-and facilityspecific considerations that limit the utility of assumptions from one facility at another facility.

Care must be taken to clearly identify assumptions believed to over predict consequences (e.g., higher infiltration rate through a cover than expected, early failure of liners) and to place any negotiated scenarios in context of how the scenarios relate to performance that would typically be expected. This 
can be viewed in the context of defense-in-depth. Such documentation can be used to provide proper context relative to comparisons that may be made and to support conducting additional cases, where it is desirable to provide a more realistic representation for a given assumption.

\subsection{Timing Considerations for Covers, Liners and System Performance}

PAs conducted to date have identified some common concerns related to timing assumptions for failure of covers and liners in the context of a demonstration of compliance. It is important to develop an understanding of the significance of the relative timing of assumptions for the loss of performance for cover and liner systems. Two examples of timing related concerns are:

1) If too much credit is taken for cover and liner performance, peak impacts can be artificially delayed beyond the 1,000 year compliance time, and

2) If the liner system is assumed to fail early allowing early releases to the environment, the assessment could be portrayed as not addressing the potential for cover degradation prior to liner degradation, increased infiltration, and potential for accumulation of water on the intact liner and overflow (e.g., bathtub effect). This could result in an increased release rate when the liner system does fail (potential pulse release), as the accumulated water drains potentially leading to higher peak concentrations in the environment.

These two topics illustrate some of the challenges associated with addressing performance of cover and liner systems given the uncertainty regarding the timing of when cover and liner systems will cease to be effective. Example 1 is associated with a concern about over-predicting the effectiveness of covers or liners (taking too much credit). In this case, the concern is that taking too much credit for the effective life of cover and liner systems could lead to peak impacts occurring after 1,000 years, the time of compliance in DOE Order 435.1. Although, in principle, design features that delay releases should be considered a positive, concerns with the magnitude of any delayed peaks should be addressed. Such concerns can be addressed in the context of DOE Order 435.1 by discussing the significance of any peaks that would be expected to occur after 1,000 years in the context of risk-informed decision-making.

Example 2 is associated with intentionally assuming a liner system increases in permeability early, allowing early release of leachate, to avoid having to defend a longer lifetime for the liner system. Allowing for early releases can give the impression of leading to larger peak doses, but it can miss the potential impacts of water accumulation in the facility prior to liner failure (e.g., bathtub). This highlights the interrelationship between cover and liner system performance. If the cover begins to allow increased infiltration prior to loss of performance of the liner system, there is potential for accumulation of water on the liner system. The accumulated water would be in contact with the waste for an extended time prior to release. This could, under certain circumstances, result in a pulse release as the liner system increases in permeability and lead to greater impacts than assuming failure of the liner system, for example, at 100 years. Although, it will be important to consider how flow through flaws in a multilayer liner system would actually occur (i.e., it would not be expected to freely drain with no resistance). Such timing considerations are an important aspect to be considered in a strategy to address cover and liner systems in a PA.

\subsection{Defense-in-Depth Principles}

Defense-in-depth principles should be considered as part of design, operations, assessment and closure of a disposal facility. In many cases, features are included in cover and liner systems, but no credit is taken in the assessment. It is important to capture such considerations in the context of defense-in-depth (i.e., expected performance that is not credited in the PA). The role of design and operational considerations is 
emphasized in this report as means to help manage uncertainties that may be difficult to resolve in an assessment. Any DOE LLW disposal system must be designed, constructed, operated, and closed with a reasonable expectation that DOE O 435.1 requirements and performance objectives will be met. For CERCLA cells, in addition to meeting performance objectives they must also meet the CERCLA threshold criteria. Defense-in-depth in the context of this report means considering, and possibly including the following in the requirements for an on-site disposal facility:

- Siting and Design requirements,

- Waste form requirements,

- Performance-based requirements such as dose limits, operational requirements, etc., and

- Closure requirements.

The CERCLA ARAR's process performs much of this function by selecting applicable or relevant and appropriate chemical-specific, action-specific, or location-specific ARARs most appropriate for the remedial action (disposal cell development). Where there are identified gaps in the requirements/safety envelope, to-be-considered (TBC) guidance or other non-promulgated specifications (such as DOE Order requirements) can be added to enhance the response action. 


\subsection{General Approach to Consider Covers and Liners}

A number of years of DOE experience have been gained from assessments of the long-term performance of disposal facilities involving covers, liners and leachate collection systems. For example, the Office of Legacy Management currently provides surveillance and maintenance on numerous closed disposal facilities including three CERCLA disposal facilities: Weldon Spring, Fernald, and Monticello. The Monticello Site is an UMTRA facility that was completed under CERCLA. There are three active CERCLA disposal facilities including Oak Ridge, Hanford, and Idaho National Laboratory (INL) that all dispose of LLW, HW and MW. There are a total of twenty-four (24) Title I UMTRA disposal facilities around the DOE complex.

This practical experience of design, build, operate and closure of radioactive and hazardous waste disposal facilities has reached a point where it is timely to formulate and offer a more consistent approach to address long-term performance of covers and liners; especially the uncertainties associated with the evolution of such barriers over time. Recently, the NRC Office of Nuclear Regulatory Research held a workshop in 2010 on this topic (Nicholson and Arlt 2011) and supported a large study on long-term cover performance (Benson et. al 2011). These activities also provided insights into consideration of long-term performance of cover and liner systems.

This report provides a structured approach for such assessments and provides information that can be used to help explain cover and liner system performance to stakeholders, starting at a higher level and working towards detailed information for calculations. The actual approach is presented in four steps:

1) Define the assessment of cover and liner systems in the context of a total system perspective, considering the evolution over time of water balance and how water migrates through the cover, waste, liners and the natural system,

2) Develop conceptual models starting with identification of the functional roles (safety functions) of the different components of covers and liners. This is done in the context of limiting releases from disposal facilities, including identification of the relative importance of different components depending on the local climate (e.g., "wetter" versus "drier" sites, freeze-thaw),

3) Identify events and processes that can result in changes to those components and how those changes can influence the performance of given components, including perspective regarding their relative significance based on existing experience, and

4) Synthesize information into integrated scenarios to be used to meet the performance requirements of DOE Order 435.1.

Additional information for each of these steps is summarized below. In practice, there will be iterations among the different steps and there should be substantial interaction with the LFRG and stakeholders (e.g., EPA, state agencies, members of the public) to ensure that their concerns are addressed. The remainder of this report provides increasing detail to implement each of the steps in the approach. The information is intended to help with implementation of the graded approach and can also be used to develop information for stakeholders to explain the performance of cover and liner systems.

The primary emphasis of this report is on considerations related to water flow and associated transport of contaminants. However, for example, covers also serve a role as barriers to biotic or inadvertent human intrusion into the waste and liners can be designed to serve as "chemical" barriers targeting specific contaminants in addition to managing water. Although not the primary focus, these roles will also be addressed as appropriate. 


\subsection{Step 1: Develop Initial Representation of Total Disposal System}

The first step in the process is to consider the full disposal system and to begin to define the overall approach. This starts with development of an initial perspective regarding the expected water balance and flows through the system, and how the water balance is expected to evolve over time. Initially, the focus can be at a level of cover, waste, liner, and natural system rather than the detailed layers within each of these. This perspective can be helpful for a high-level description of the system for stakeholders. Considerations related to potential accumulation of water have proven to be a significant area of interest (e.g., bathtub above the liner system) and should be an emphasis. This will have a significant influence on how ranges of values for assumed performance of different layers are developed and scenarios for evolution of the system are defined. The definition of water balances within each layer will be refined over time as the specific features within each of these layers are better defined. Additional information for this step is provided in Section 4.0, Total Disposal Systems Perspective.

\subsection{Step 2: Develop Initial Conceptual Models for Each Layer}

This step involves identification of the specific design components in each layer and the functional roles (safety functions) those components are expected to serve in terms of managing water and migration of contaminants. The intent at this point is to provide an initial perspective of the necessary performance for different features (e.g., evapotranspiration (ET) layer is expected to address "x"\% of the average precipitation and " $y$ " peak precipitation events). Initial perspective can also be provided about the relative significance of different layers in terms of performance (e.g., is it expected to be a primary feature or a redundant feature based on expected conditions). However, it is important to err on the side of inclusion rather than exclusion in cases where there is not a clear basis. Details regarding the material properties assumed for each layer should be specified at this time along with how different layers will be linked in terms of the actual modeling (e.g., cover and waste will be addressed independently, then linked assuming an infiltration rate through the base of the cover as a boundary condition for the waste layer). Detailed information to support development of the initial conceptual models is identified in Section 5.0, Conceptual Description of the Disposal System. Specific information and detailed tables are also provided in Section 6.0, Functional Roles of Cover System Components, and Section 7.0, Functional Roles of Liner System Components.

\subsection{Step 3: Quantify Evolution/Degradation}

This step involves identification of events and processes that can impact the performance of the design components over time. The term evolution is used to reflect that changes can improve or degrade performance of different layers over time, but the general focus of this effort is on events and processes that result in degradation of the performance of design components in the context of their defined functional roles. The emphasis of this step should be prioritized based on the components deemed to be most critical to performance. This is generally viewed as the most challenging aspect for assessments of covers and liners. Specific information regarding identification of events and processes are provided in Section 8.0, Factors Influencing Evolution of Covers and Liners. Detailed approaches for quantifying the evolution are provided in Section 9.0, Technical Information about Long-Term Evolution of Covers and Liners.

As discussed previously, the extent to which the evolution of cover and liner systems is taken into account and justified within PAs generally depends upon the extent to which credit must be taken for the performance of the cover and liner system within the PA. The need to justify and take into account cover and liner system evolution often diminishes as the cover and liner system become a defense-in-depth component for which little credit is given within the PA relative to reducing contaminant release out of 
the disposal facility recognizing that releases are likely being over-predicted (a caveat must be made for potential counter-intuitive results discussed in Section 2.2, Timing Considerations for Covers, Liners and System Performance). In any case, it is important to document what is and is not credited in the PA.

There is expected to be significant uncertainty regarding the specific timing and extent of changes in performance of different materials. Thus, there is expected to be iteration on this step involving development of ranges of values and then considering the implications of those ranges of values in the context of the total system (e.g., timing of cover degradation relative to liner degradation assumptions). Sensitivity analysis can be used to help identify the components and assumptions that have the greatest influence. Evolution should be quantified in the context of changes in material properties and the timing of those changes. In many cases, it can be valuable to consolidate the detailed results for each component into lumped representations of the cover and liner systems, respectively (e.g., net infiltration to the waste, net permeability of the liner system). Such an approach can be easier to implement in the PA model used for compliance.

It is expected that assumptions regarding evolution of the covers and liners over time will be an area of interest for LFRG and stakeholders. Care must be taken to not make generic assumptions about what might overestimate the degradation of liners and/or maximize the release and exposures from the disposed waste. It is necessary to consider such assumptions in the context of performance of the total system (e.g., assuming immediate degradation of the cover or liner at 100 years may not always result in upper end estimates of contaminant release and/or exposure). Adopting some bounding assumptions as extremes can be useful for initial screening to provide perspective (e.g. complete failure of cover and liner at 100 years), but in general it is suggested to provide some ranges of values that are more representative of what would be expected to occur. This information will be specific to the site and facility considered. The output from this step should provide a basis for identification of evolution scenarios to be considered in a total system assessment.

\subsection{Step 4: Identify Total System Scenarios to be Considered}

This step involves a synthesis of the information identified in the first three steps into one or more representative scenarios that address evolution of the different components of the system over time. These scenarios should be defined from a total system viewpoint, where the cover is represented by a net infiltration rate as a function of time and the liner system is represented with a changing rate of drainage to the vadose zone with time. Such approaches would rely on the detailed quantification of performance considering the individual components in the cover and liner system conducted in Step 3.

The LFRG and stakeholders have shown high levels of interest for this step in the process. It is desirable to work with them as the scenarios to be considered are developed. Generally, it should be expected to consider a few scenarios to capture the impacts of different timing assumptions that impact the water balance and eventual releases from the disposal system to the environment. For example, it can be useful to include cases expected to represent relatively early degradation, if such extreme cases can illustrate the robustness of the system. However, it should not be considered essential to consider extremes for a compliance calculation and it is not advisable to include scenarios that are clearly beyond the realm of reasonable possibilities. A logical approach is to strive to develop a realistic set of scenarios that capture the ranges of conditions that are developed in Step 3. In the end, the final design and assumptions can be integrated into a facility WAC that will establish limits for what can be accepted for disposal. 


\subsection{Total Disposal System Perspective}

A total systems approach considers the inter-relationship among assumptions regarding covers, the waste, liners, and the natural system as a unit when addressing overall performance. The roles of these different features need to be considered together in the context of the impact on water flow through the system and migration of contaminants. These interactions can change as a function of time as the facility evolves from operations to institutional controls to the time frame where the system is no longer actively maintained. The detailed PA considerations described later in this report emphasize cover and liner performance, but from a systems perspective, the role of the waste as a water storage buffer also needs to be considered. Figure 4-1 is a rough schematic illustration of considerations for water balance and the links between the different parts of the system. Note that the potential for lateral migration of water from areas outside the facility (e.g., surface or via natural capillary barriers) into the facility also needs to be addressed.

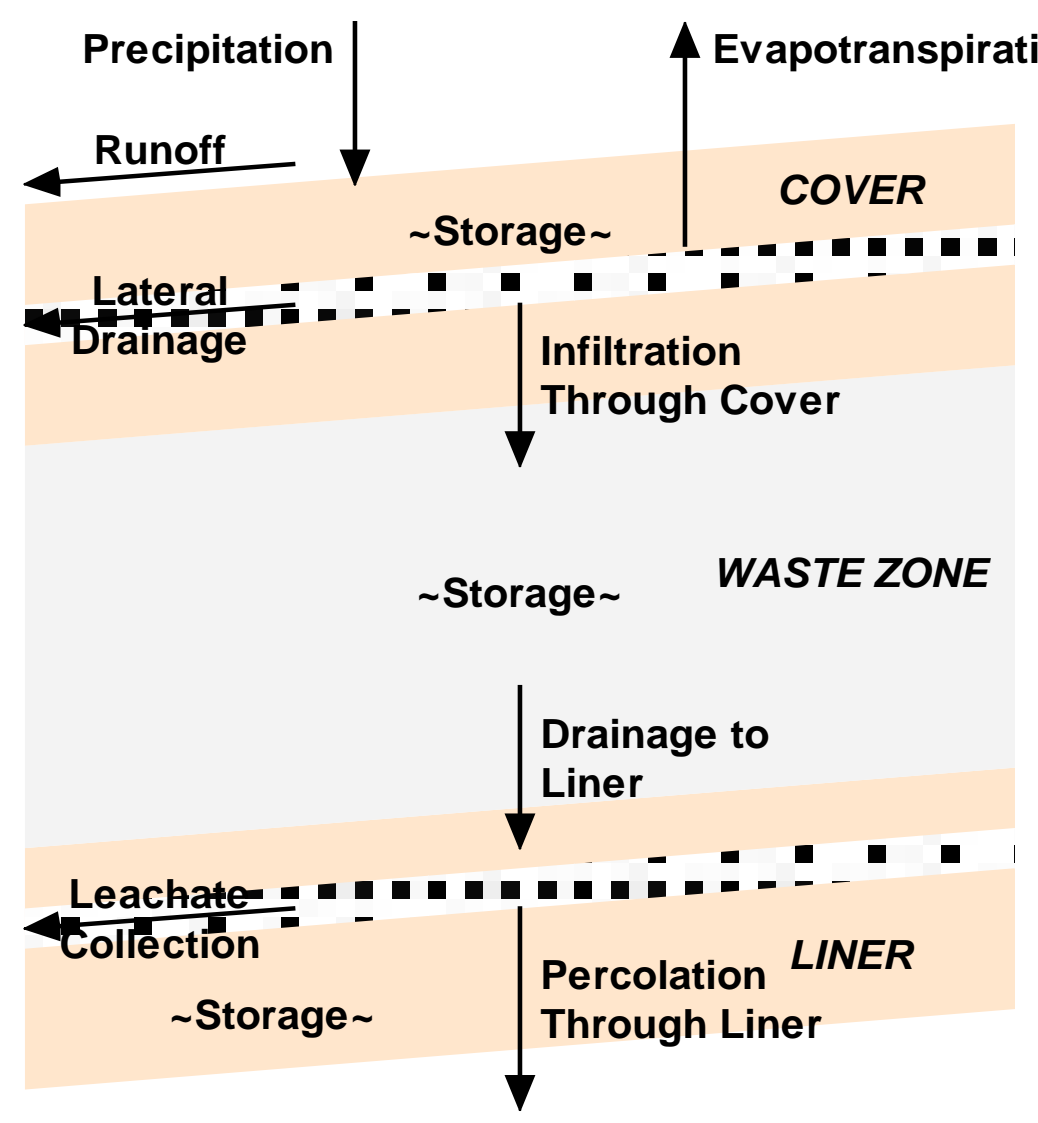

Figure 4-1. High-Level Perspective of Water Balances.

The links from a water balance perspective between each layer are straightforward (water flux). When the barriers and materials in a disposal facility are considered as a system, it provides the ability to identify the interplay among different parts of the system. As discussed previously, a systems approach helps to identify circumstances that may not be intuitive at a first glance, for examples:

- Assuming that a cover loses effectiveness early in time allowing greater percolation does not always result in the greatest dose (e.g., a cover that performs extremely well for a long time, 
when combined with disposal of radionuclides with progeny of concern, can delay releases allowing in-growth of progeny posing greater risks in the waste form at the time when flow through the cover increases).

- Assuming that a liner increases in permeability early does not always result in the greatest dose (e.g., a lined disposal facility where the liner is very effective and remains intact for a longer time than the cover, can result in accumulation of water in the waste providing a larger hydraulic driving force and potentially enhanced contaminant concentration that could result in greater releases when the liner system increases in permeability and also leachate to migrate to the environment).

From a practical perspective, key factors to consider as part of the total systems approach to improve understanding and refine designs include evolution of water balance over time and links between water balance and the evolution of the source term (inventory, waste form, containers). Given the large uncertainties associated with long-term performance of liners and covers, it is generally suggested to consider approaches that address ranges of values for degradation of different layers to illustrate how assumptions influence overall performance of the system. These topics are briefly introduced in the context of the total system perspective in the following sections.

\subsection{Evolution of Water Balance in the System}

Although "chemical” barriers can be incorporated into liner systems, tracking water through the system as a function of time is a key starting point to understanding the relative significance of different design features and to examine how roles change over the life of the facility. Such an approach is also an effective tool to help communicate an understanding of the system to stakeholders and explain expected performance of the system over time. Figure 4-2 is an example illustration of how the movement of water changes for different components with time using arrows to illustrate the flow of water (FBP 2013).

The figure also provides perspective regarding the timing of the effectiveness of different barriers and the changes of moisture levels in the waste. During operations, significant amounts of water are introduced and will drain through the waste. This leachate will be collected. The waste is relatively moist during this time. When the cover is in place and leachate collection continues, excess moisture from the waste will drain. While the cover continues to effectively minimize any infiltration into the waste, the waste will remain at a relatively dry equilibrium state. As the layers of the cover begin to degrade, increased infiltration into the waste occurs and the moisture content increases again and flow will begin to occur through the waste. As infiltration increases through the cover and the liner is intact, there is potential for moisture contents to reach a point where there can be accumulation of water above the liner (i.e. positive head). Finally, as the liner system becomes more permeable, any accumulated water would drain at the rate based on the permeability of the liner system (i.e., synthetic and natural materials) and then the system will approach a steady state flow from the cover through the waste and the liner. Note that it is important to consider designs that reduce the likelihood of an instantaneous catastrophic failure of the liner system that could result in a pulse release of concentrated leachate that has been accumulating on the intact liner system.

Table 4-1 provides additional information related to water balance considerations for covers, the waste and liners during operations, institutional controls, and following institutional controls. Conceptual model development to address these considerations is discussed in Section 5.0, Conceptual Description of the Disposal System. 


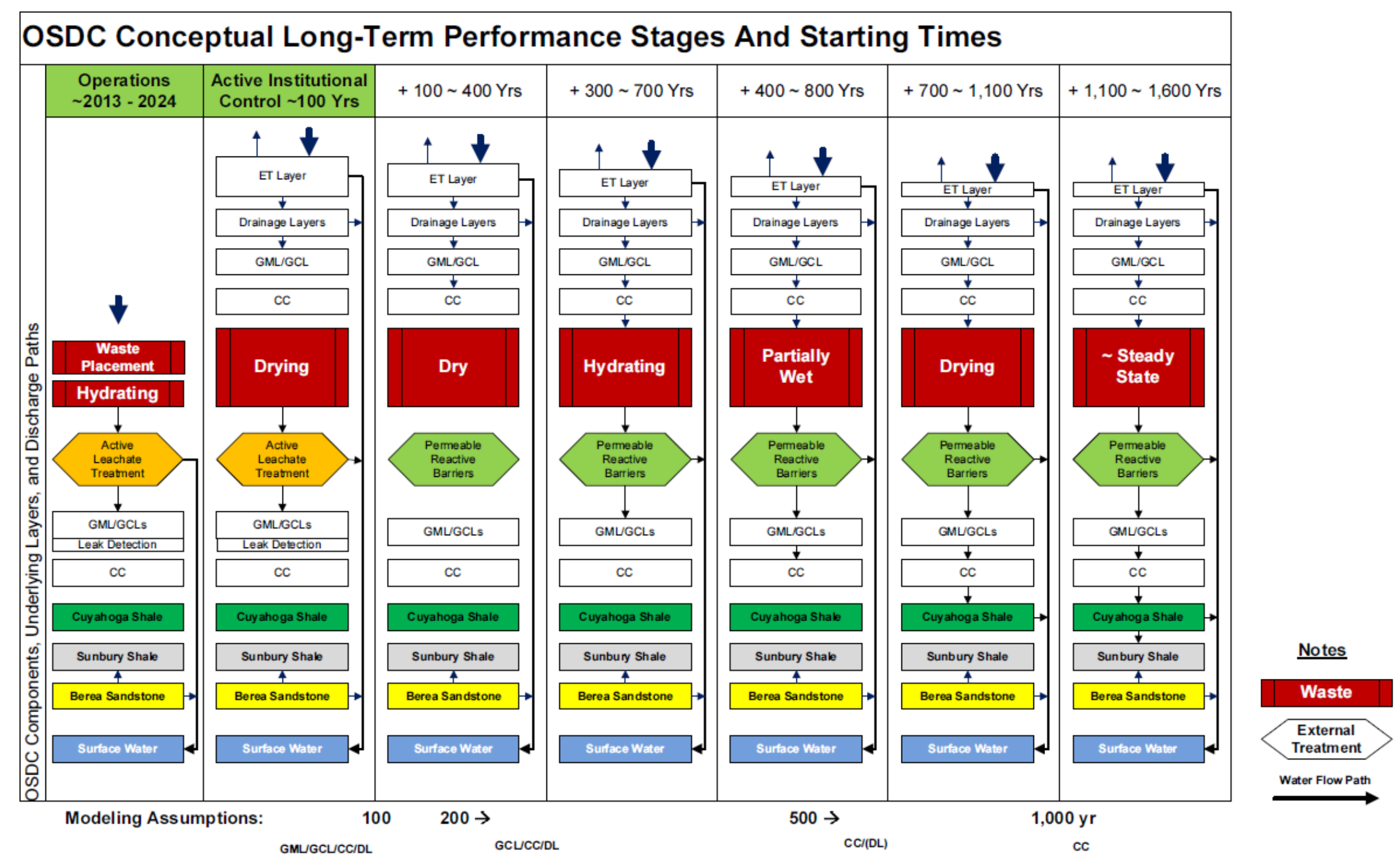

Figure 4-2. Example of the Evolution of Water Balance Over Time (Arrows Denote Water Movement) (FBP 2013). 
Table 4-1. Summary of Water Balance Considerations at Different Times.

\begin{tabular}{|c|c|c|c|}
\hline & $\begin{array}{c}\text { Operations } \\
\text { (10s of years) }\end{array}$ & $\begin{array}{c}\text { Institutional Control } \\
\text { (typically } 100 \text { years) }\end{array}$ & $\begin{array}{c}\text { Post-Institutional Control } \\
\text { (hundreds/thousands of years) }\end{array}$ \\
\hline Cover & $\begin{array}{cl}\text { Precipitation on operational } \\
\text { covers } & \\
- & \text { Runoff } \\
- & \text { Promote ET } \\
- & \text { Limited } \\
& \text { effectiveness to } \\
& \text { decrease infiltration } \\
& \text { to waste }\end{array}$ & $\begin{array}{cl}\text { Precipitation on Final cover } \\
- & \text { Runoff } \\
- & \text { Promote ET and } \\
& \text { storage } \\
-\quad & \text { Lateral drainage (i.e., } \\
& \text { interflow) } \\
-\quad & \text { Infiltration to waste } \\
& \text { significantly reduced }\end{array}$ & $\begin{aligned} & \text { Cover performance can degrade with } \\
& \text { time } \\
& \text { - } \text { Runoff } \\
&- \text { Promote ET (storage) } \\
& \text { - } \text { Lateral drainage } \\
& \text { - } \text { Increasing infiltration to } \\
& \text { waste }\end{aligned}$ \\
\hline Waste & $\begin{array}{l}\text { Direct precipitation and } \\
\text { water introduced for dust } \\
\text { suppression/compaction } \\
\text { - } \quad \text { Increased moisture } \\
\text { content (storage) } \\
\text { and drainage to } \\
\text { liner system } \\
\text { - } \quad \text { Large quantities of } \\
\text { leachate } \\
\text { - Source depletion in } \\
\text { leachate }\end{array}$ & $\begin{aligned} & \text { Limited added Infiltration to } \\
& \text { waste } \\
& \text { - } \text { Moisture content } \\
& \text { (storage) decreases } \\
& \text { - } \text { Drainage of stored } \\
& \text { water accumulated } \\
& \text { during operations to } \\
& \text { liner system } \\
& \text { - } \\
& \text { Source depletion in } \\
& \text { leachate }\end{aligned}$ & $\begin{array}{c}\text { Increasing Infiltration to waste } \\
\text { - } \quad \text { Moisture content (storage) } \\
\text { based on infiltration rate } \\
\text { - } \quad \text { Potential accumulation of } \\
\text { water on primary barrier } \\
\text { (inactive leachate collection } \\
\text { system) } \\
\text { Can also be situations where } \\
\text { infiltration decreases over time, such } \\
\text { as an aggrading or depositional } \\
\text { environment }\end{array}$ \\
\hline Liner & $\begin{array}{cl}\begin{array}{l}\text { Leachate drainage to liner } \\
\text { system }\end{array} & \\
- & \text { Active leachate } \\
& \text { collection } \\
- & \text { Synthetic liner } \\
& \text { intact, minimal } \\
& \text { percolation to } \\
& \text { natural system }\end{array}$ & $\begin{array}{cl}\begin{array}{l}\text { Leachate drainage to liner } \\
\text { system }\end{array} & \\
\text { - } & \text { Active leachate } \\
& \text { collection } \\
\text { - } & \text { Potentially discontinue } \\
& \text { leachate collection as } \\
& \text { excess water in waste } \\
& \text { layer drains } \\
\text { - } & \text { Potential accumulation } \\
\text { - } & \text { of water in sump } \\
& \text { Synthetic liner intact, } \\
& \text { minimal percolation to } \\
& \text { natural system }\end{array}$ & $\begin{array}{l}\text { Leachate drainage to liner system } \\
\text { - } \quad \text { Lateral migration to leachate } \\
\text { collection sump while liner } \\
\text { intact } \\
\text { - } \quad \text { Potential accumulation of } \\
\text { water in leachate collection } \\
\text { sump } \\
\text { - } \quad \text { Clay or other materials } \\
\text { below synthetic liner limit } \\
\text { releases } \\
\text { - Percolation to natural } \\
\text { system increases as cover } \\
\text { and liner system degrades }\end{array}$ \\
\hline $\begin{array}{l}\text { Natural } \\
\text { System }\end{array}$ & $\begin{array}{l}\text { Minimal potential } \\
\text { percolation from liner } \\
\text { system } \\
\begin{array}{cl}- & \text { Reduction in } \\
& \text { moisture content } \\
& \text { below liner system }\end{array}\end{array}$ & $\begin{array}{l}\text { Minimal potential percolation } \\
\text { from liner system } \\
\text { - } \quad \text { Moisture content } \\
\text { remains lower under } \\
\text { liner system }\end{array}$ & $\begin{array}{cl}\text { Increasing percolation from liner } \\
\text { system } \\
- & \text { Moisture content below } \\
& \text { liner system increases as } \\
& \text { liner system degrades } \\
- & \text { Flow will be primarily } \\
& \text { controlled by unsaturated } \\
& \text { hydraulic conductivity } \\
\text { Can also be constant or decreasing } \\
\text { percolation in cases where recharge } \\
\text { is constant or decreasing over time }\end{array}$ \\
\hline
\end{tabular}




\subsection{Conceptual Description of the Disposal System}

From a high-level functional perspective, covers and liner systems serve the general purpose of managing water/leachate. In the case of a cover, the purpose is to limit the amount of water that reaches the waste beneath the cover. The purpose of a liner system is to limit downward migration of leachate that has formed due to prolonged water contact with the waste and mitigating contamination of the underlying vadose zone and groundwater. This includes collecting water that passes through the waste during operations and time of institutional controls, and to serve as a barrier limiting flow rates and potentially chemically serving to retard migration into the natural system over longer times. The following sections include descriptions of typical components included in different types of covers and in liner systems. Detailed tables are then provided that describe specific functional roles of the different components. This information is intended as a first step towards the definition of the processes that need to be considered in a conceptual model.

\subsection{Conventional Covers}

Conventional covers are typically required in wetter, humid locations where annual precipitation exceeds annual ET. Conventional covers rely on a combination of ET and lateral drainage to limit infiltration into the waste zone (runoff is also considered, but typically has a minor role). Figure 5-1 provides an example of a conventional LLW disposal facility cover (FBP 2013). ET is promoted by the vegetation, topsoil, and soil water storage layer. Lateral drainage (also called interflow) is promoted by the higher permeability drainage layer, which is underlain by a low permeability layer (e.g., composite barrier (combination of geomembrane and GCL and/or CCL)). ET is a significant contributor to the water balance of conventional covers utilized in humid locations, but ET is generally supplemented with lateral drainage in order to sufficiently manage infiltration.

Considerations related to the local topography are also important for cover designs. For example, there are different considerations for drainage for above grade cells and below grade cells. Likewise, disposal cells on sloped land include specific design considerations to manage water. For example under intact cover conditions at the Savannah River Site (SRS) for a below grade facility on relative flat land, where there is an average 49 inches of precipitation a year, the water balance is divided into 66\% ET, 33\% lateral drainage, $\sim 1 \%$ runoff, and much less than $1 \%$ infiltration into the waste zone (Phifer et al. 2007). Under intact cover conditions at Oak Ridge, where the facility is built on the side of a ridge and there is an average precipitation of 54.4 inches/year, the water balance is divided into $~ 58 \%$ evapotranspiration, $\sim 40 \%$ lateral drainage, $1 \%$ runoff, and much less than 1\% infiltration into the waste zone (Jacobs 1998). Under intact cover conditions at Portsmouth, where the facility is built on top of a shale hill and there is an average precipitation of 39.5 inches/year, the water balance is divided into $~ 70 \%$ evapotranspiration, $\sim 22 \%$ lateral drainage, $\sim 8 \%$ runoff, and much, much less than $1 \%$ infiltration into the waste zone (FBP 2013). As the cover degrades the level of ET remains essentially the same but the lateral drainage decreases and the infiltration increases (Phifer et al. 2007).

In general PAs conducted for conventional covers in wetter, humid locations will take credit for the reduction in infiltration resulting from the use of the conventional cover in order to demonstrate compliance with standards. To the extent to which the conventional cover is credited with reducing infiltration over time, sufficient justification must be provided for the associated cover evolution as properties of the cover materials change with time. 
SRNL-STI-2014-00409

Revision 0

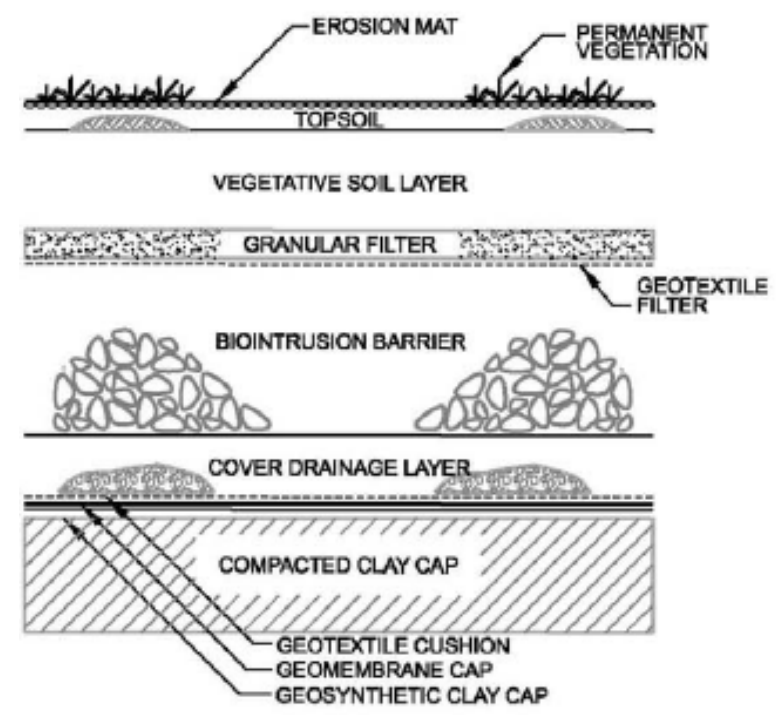

Figure 5-1. Conventional LLW Disposal Facility Cover (Generally in Cases with Precipitation > ET) (FBP 2013).

\subsection{Evapotranspiration Covers}

ET covers are typically suitable in drier locations where annual precipitation is much less than the annual evapotranspiration potential such that minimal deep infiltration naturally occurs. ET covers emphasize the collective processes of evaporation, transpiration, and soil-water storage to control infiltration into the waste zone. Depending on site-specific conditions, ET covers may also include lateral drainage layers to accommodate excess infiltration. Figure 5-2 provides two examples of ET covers (EPA 2011). ET covers are designed to have a sufficient thickness of fine grained soil such as silts and clayey silts so that sufficient soil water storage is provided to accommodate periods of excessive precipitation for later ET. ET covers are generally designed to be able to manage the expected precipitation via ET alone. For example, at the Hanford site, the annual average precipitation is roughly $7 \mathrm{in} / \mathrm{yr}$ and ET can account for $99+\%$ of the water balance. The storage layer needs to be sufficient to address higher precipitation events, but in general, a basic cover provides sufficient protection. Additional assurance can be provided by including a coarse grained layer that will provide a capillary break. In some cases, ET type cover layers can be combined with designs including drainage and composite barrier layers for defense-in-depth, where warranted. Additionally, because ET is also an important water removal mechanism in conventional covers, ET design principles should be considered for the design of conventional covers.

In general ET covers can be suitable for drier locations. ET covers do not necessarily include the use of drainage and hydraulic barrier layers. However if ET covers do include drainage and hydraulic barrier layers, such layers are often considered defense-in-depth components, for which little or no credit needs to be taken for reducing infiltration to the waste zone within the PA in order to demonstrate compliance with standards. Often the infiltration through ET covers is compared with background infiltration through native soils at the arid location. In such cases little justification is necessary relative to the evolution of the drainage and hydraulic barrier layers. However justification of the potential evolution of the soil-water storage layer (fine-grain layer in Figure 5-2) and vegetation for the promotion of ET would be required. A caveat must be made for potential counter-intuitive results associated with the use of drainage and hydraulic barrier layers as simply a defense-in-depth without consideration within the PA as discussed in Section 2.2, Timing Considerations for Covers, Liners and System Performance. However this is probably less of a concern for ET covers in arid locations than for conventional covers in humid locations. 

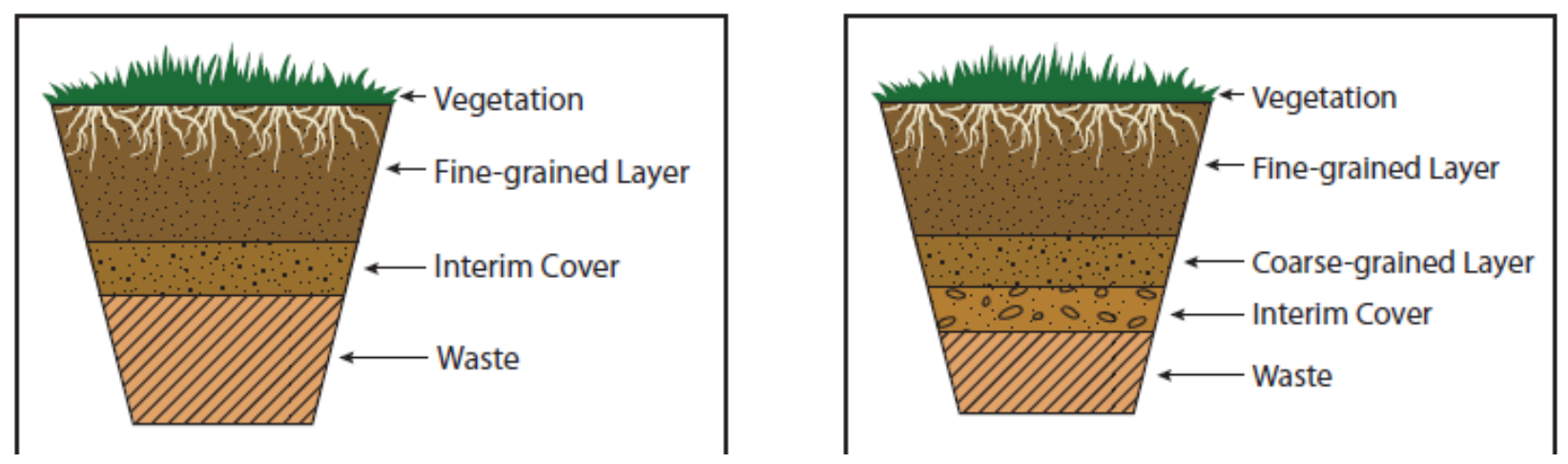

Figure 5-2. ET Cover Designs (EPA 2011) (ET > Precipitation). Left Figure is a "Monolithic" ET Cover and Right Figure is a "Capillary Barrier" ET Cover.

\subsection{Liner and Leachate Collection Systems}

For DOE CERCLA disposal cells, a double liner system is typically utilized where both leachate collection and leak detection are required. Figure 5-3 provides an example of a LLW disposal facility double liner system (FBP 2013) and a photo of the Weldon Spring disposal cell. The leachate collection system provides for lateral drainage and for the collection and removal of leachate from the LLW disposal facility during the operations and institutional control periods. Materials can also be included in the design that target sorption of specific radionuclides or other contaminants. The leak detection system is designed to detect leaks through the primary liner during the operation and institutional control periods and to provide a secondary barrier against releases to the environment. Generally it is not planned to extend operations of the leachate collection and leak detection systems beyond the institutional control period. In some cases, it is expected to discontinue leachate collection prior to the end of institutional controls depending on the rate at which excess moisture drains from the waste layer after the cover is in place.

For example, the Weldon Spring cell (Figure 5-3) was closed in 2002 and the final cap was placed over waste generated during cleanup of the Chemical Plant and Quarry. The Office of Legacy Management is responsible for performing surveillance and maintenance of the facility including the leachate collection system. The amount of leachate has decreased rapidly over ten years and leachate is sampled semiannually (Powell et al. 2011a). Similarly, the Fernald on-site disposal facility was completed in 2006. Since closure and completion of the cover, the leachate volume decreased very quickly and has essentially leveled off at a very low monthly quantity (Powell et al. 2011b). These operational examples illustrate the expectation that active leachate collection can very likely be discontinued well before the end of active institutional controls. 

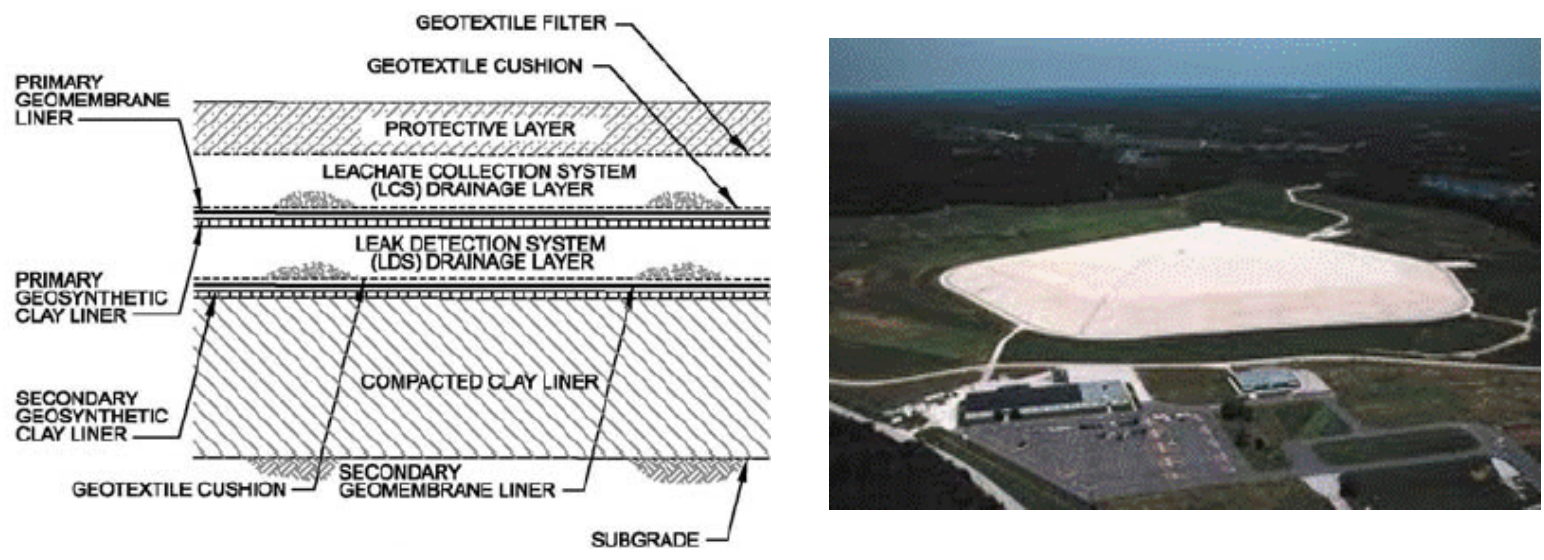

Figure 5-3. Typical Double Liner System (FBP 2013) and the Weldon Spring Disposal Cell.

\subsection{Waste Layer}

The waste layer influences water flow and can also influence the release rate of contaminants from a waste form into leachate. From a water management perspective, the waste layer serves as pore space for water storage and a delay between infiltration from the base of the cover to collection of water on the liner. Although "design" of the waste layer is largely based on the properties of the waste to be received, there can be design considerations for specific waste forms (especially for subsidence considerations). The bulk movement of water that infiltrates through the cover is generally controlled by the unsaturated flow properties of the bulk wastes (e.g., soils) disposed in a facility. At a dry site, the storage capacity in the waste layer with a cover in place can be significant relative to the amount of infiltration that occurs. This can significantly delay the potential accumulation of water on a liner system after leachate collection is discontinued.

Individual waste forms can also be designed to control the release of radionuclides physically and chemically. Containers (e.g., steel, cementitious) can effectively isolate specific wastes from infiltrating water for an extended period of time. Large scale grouting of selected wastes (e.g., debris) can also serve to reduce releases. Although, releases can be influenced, localized containers or grouting are not generally assumed to have a significant influence on the management of water through the waste layer in a large facility. Specific waste forms can also influence releases. For example, activated metals (especially stainless steel) can significantly reduce releases of radionuclides such as Ni-63, Ni-59, and C-14 that can be entrained within the metal matrix. 


\subsection{Functional Roles of Cover System Components}

The primary function of a cover system is to control infiltration of water into the waste by encouraging ET and lateral rather than downward flow of water. Table 6-1 provides a breakdown of the typical layers within a conventional cover and their associated function in limiting infiltration into the waste. The ET layer typically consists of a vegetative cover, topsoil, and a soil water storage layer. The primary functions of the ET layers are to remove water from the cover system through ET, soil-water storage, and runoff in order to limit infiltration, while also controlling erosion. The relative significance of these will vary based on site and design specific considerations.

The biointrusion layer may consist of a granular filter, a geotextile filter fabric, and rip rap or cobbles. The primary functions of biointrusion layer are to prevent burrowing animals from damaging underlying components and creating continuous macropores into the waste, prevent exposure to burrowing animals, mitigate animals from bringing contamination to the surface, and potentially mitigate inadvertent human intrusion. Additionally, the biointrusion layer may act as a deterrent to the basement intruder scenarios by serving as a warning that something is different here and also maintaining a minimum height of clean material above the waste to preclude penetrating into the waste during basement construction. The biointrusion layer may also serve as a capillary break and provide some deterrent to root penetration and plant uptake of contamination, but this function would need to be justified over an extended time period (i.e., 1,000 years), which could include consideration of local natural analogues, if available. Some biointrusion materials can also serve as a limiting layer for potential erosion. A biointrusion layer can also promote lateral drainage (see below).

The lateral drainage layer may consist of a granular filter; a geotextile filter fabric; a geonet and/or gravel/sand; and a geotextile protective fabric overlying a composite barrier which may consist of a geomembrane (typically HDPE) and a GCL and/or a CCL. The primary function of the lateral drainage layer, in conjunction with the underlying composite barrier, is to divert infiltrating water away from the underlying waste and transport the water to the perimeter drainage system thus minimizing infiltration into the waste. Additional details concerning the function of the cover system components are provided in Table 6-1. 
Table 6-1. Functional Roles of Typical Cover Components.

\begin{tabular}{|c|c|c|}
\hline Layer & Potential Subcomponents & Function \\
\hline $\begin{array}{l}\text { Cover System } \\
\text { Overall }\end{array}$ & - & $\begin{array}{l}\text { The primary function of the cover system is to control infiltration into the waste. The entire cover system } \\
\text { thickness can be specified to provide the necessary thickness to preclude biointrusion by either animals or } \\
\text { roots based on local conditions. }\end{array}$ \\
\hline $\begin{array}{l}\text { Evapotranspiration } \\
\text { (ET) Layer }\end{array}$ & $\begin{array}{l}\text { - Vegetative Cover } \\
\text { - Topsoil } \\
\text { - Soil Water Storage } \\
\text { Layer } \\
\text { - Capillary Break }\end{array}$ & $\begin{array}{l}\text { The primary functions of the ET layer are to remove water from the cover system by promoting a } \\
\text { combination of ET and soil-water storage in order to minimize infiltration, while minimizing erosion. In } \\
\text { humid environments ET may be the primary means of removing water from the cover system, while in arid } \\
\text { environments covers may consist of only an ET layer designed to remove essentially all water through } \\
\text { adequate water storage and ET (i.e. ET covers). The promotion of runoff must be balanced versus the } \\
\text { minimization of erosion. The ET layer materials are selected and the top of cover slopes (typically range } \\
\text { from } 2 \text { to } 5 \% \text { slope) are designed to minimize erosion and prevent the initiation of gullying. The } \\
\text { vegetative cover promotes runoff, minimizes erosion, and obviously promotes transpiration. The topsoil } \\
\text { and underlying soil water storage layer support the vegetative cover, promote runoff, help minimize } \\
\text { erosion, and provide water storage for the promotion of ET. A capillary break helps to maintain water } \\
\text { storage in the overlying ET layers for the promotion of ET and runoff. }\end{array}$ \\
\hline Biointrusion Layer & $\begin{array}{l}\text { - Granular Filter } \\
\text { - Geotextile Filter Fabric } \\
\text { - Rip Rap or Cobbles }\end{array}$ & $\begin{array}{l}\text { The primary functions of biointrusion layer are to prevent burrowing animals from damaging underlying } \\
\text { components and creating continuous macropores into the waste, prevent exposure to burrowing animals, } \\
\text { mitigate animals from bringing contamination to the surface, prevent further erosion, potentially act as an } \\
\text { intruder deterrent, and/or act as a deterrent to root penetration. It is generally easy to prove functionality } \\
\text { over } 1,000 \text { years relative to burrowing animals and erosion based upon rock durability testing and rock } \\
\text { stability calculations. However it is more problematic to adequately demonstrate the ability to act as an } \\
\text { intruder deterrent or act as a deterrent to root penetration over } 1,000 \text { years. Although it is difficult to } \\
\text { demonstrate that someone cannot intrude through the layer, the biointrusion layer can serve as a warning to } \\
\text { an intruder that something is different and may also be used with the other layers to maintain a minimum } \\
\text { height (typically } 10-15 \mathrm{ft}(3-5 \mathrm{~m}) \text { ) of clean material above the waste by preventing erosion beyond the layer } \\
\text { itself. This depth is generally considered sufficient to preclude the basement intruder scenario from } \\
\text { contacting the waste during construction. The biointrusion layer can also act as a capillary break to } \\
\text { maintain water storage in the overlying ET layers for the promotion of ET and runoff. The granular filter } \\
\text { and geotextile filter fabric serve to minimize migration of overlying materials into the rip rap or cobbles } \\
\text { thus maintaining the capillary break function, while the rip rap or cobbles serve to fulfill the primary } \\
\text { functions of the biointrusion layer. }\end{array}$ \\
\hline
\end{tabular}




\begin{tabular}{|c|c|c|}
\hline Layer & Potential Subcomponents & Function \\
\hline $\begin{array}{l}\text { Lateral Drainage } \\
\text { Layer }\end{array}$ & $\begin{array}{l}\text { - Granular Filter } \\
\text { - Geotextile Filter Fabric } \\
\text { - Geonet and/or } \\
\text { Gravel/Sand } \\
\text { - Geotextile Protective } \\
\text { Fabric }\end{array}$ & $\begin{array}{l}\text { The primary function of the lateral drainage layer in conjunction with the underlying composite barrier is to } \\
\text { divert infiltrating water away from the underlying waste and transport the water to the perimeter drainage } \\
\text { system thus minimizing infiltration into the waste. When the underlying composite barrier also include a } \\
\text { GCL, the lateral drainage layers serve to provide the necessary confining pressures to allow the underlying } \\
\text { GCL to hydrate properly. The granular filter and geotextile filter fabric serve to minimize migration of } \\
\text { overlying materials and penetration of the overlying rip rap or cobbles into the geonet and/or gravel/sand } \\
\text { thus minimizing the potential for clogging. The geonet and/or gravel/sand serve the primary lateral } \\
\text { drainage function. The geotextile protective fabric serves to protect the underlying geomembrane from } \\
\text { puncture or tear during placement of the overlying geonet and/or gravel/sand. }\end{array}$ \\
\hline Composite Barrier & $\begin{array}{l}\text { - Geomembrane } \\
\text { (typically high density } \\
\text { polyethylene (HDPE)) } \\
\text { - Geosynthetic Clay } \\
\text { Liner (GCL) } \\
\text { - Compacted Clay Layer } \\
\text { (CCL) }\end{array}$ & $\begin{array}{l}\text { The primary function of the composite barrier in conjunction with the overlying lateral drainage layer is to } \\
\text { divert infiltrating water away from the underlying waste and transport the water to the perimeter drainage } \\
\text { system thus minimizing infiltration into the waste. Typically a composite hydraulic barrier is utilized } \\
\text { consisting of a geomembrane underlain by either a GCL or CCL or both. Geomembranes have a very low } \\
\text { equivalent hydraulic conductivity and most water transport through a geomembrane occurs through holes } \\
\text { in the geomembrane. The GCL and/or CCL serve to hydraulically plug any geomembrane holes that exist } \\
\text { after construction or may develop over time. The geomembrane serves to separate and protect the GCL } \\
\text { and/or CCL from overlying degradation mechanisms. Together the geomembrane and GCL and/or CCL } \\
\text { form a composite barrier to infiltration into the waste. }\end{array}$ \\
\hline Foundation Layer & $\begin{array}{l}\text { - Controlled Compacted } \\
\text { Backfill }\end{array}$ & $\begin{array}{l}\text { The primary functions of the foundation layer consisting of controlled compacted backfill include: } \\
\text { - Provide structural support for the rest of the overlying closure cap, } \\
\text { - Produce the required contours and produce the required cover slope for the overlying layers, } \\
\text { - Provide a suitable surface for installation of the overlying GCL and/or CCL (i.e. a smooth surface free } \\
\text { from deleterious materials) } \\
\text { - Reduce infiltration prior to placement of rest of cover } \\
\text { - Provides additional protection of the cover system from sharp objects from the waste layer such as } \\
\text { scrap metal, structural members, etc. that could shift within the cell over time. }\end{array}$ \\
\hline
\end{tabular}




\subsection{Functional Roles of Liner System Components}

The primary function of a double liner system is to limit the percolation of leachate out of the landfill to the environment, which can include serving as a physical barrier to flow and chemically retarding migration. Table 7-1 provides a breakdown of the typical components within a double liner leachate collection system and their associated functions in minimizing percolation of leachate out of the landfill to the environment. The leachate collection system may consist of a granular filter; a geotextile filter fabric; a geonet and/or gravel/sand; perforated collection pipes; and geotextile protective fabric overlying a primary liner which typically consists of a geomembrane and an underlying GCL.

The primary functions of the leachate collection system in conjunction with the underlying primary liner are to limit downward migration and encourage lateral drainage to a sump in order to remove leachate from the landfill. This helps to limit the accumulation of leachate on the primary liner, thus minimizing leachate migration to the leak detection system during the operation and institutional control periods.

The leak detection system may consist of a granular filter; a geotextile filter fabric; geonet and/or gravel/sand; leak detection piping; and geotextile protective fabric overlying a secondary liner which may consist of a geomembrane and a GCL and/or a CCL. The primary function of the leak detection system in conjunction with the underlying secondary liner is to detect the migration of leachate from the leachate collection system through the primary liner to the leak detection system during the operation and institutional control periods.

Such multilayer liner systems help to provide a series of synthetic and natural resistors to leachate migration that will help to significantly reduce the likelihood of a sharp and significant increase in the drainage rate through the system when any single component begins to degrade. Additional details concerning the function of the various liner layers are provided in Table 7-1. 
Table 7-1. Functional Roles of Typical Double Liner Layers.

\begin{tabular}{|c|c|c|}
\hline Layer & Potential Subcomponents & Function \\
\hline $\begin{array}{l}\text { Liner System } \\
\text { Overall }\end{array}$ & - & $\begin{array}{l}\text { The primary function of the liner system is to minimize the percolation of leachate out of the landfill to the } \\
\text { environment. }\end{array}$ \\
\hline $\begin{array}{l}\text { Protective Soil } \\
\text { Layer }\end{array}$ & $\begin{array}{l}\text { - Controlled Compacted } \\
\text { Backfill }\end{array}$ & $\begin{array}{l}\text { The primary function of the protective soil layer is to prevent damage to the underlying liner system during } \\
\text { landfill operations. This layer can also be designed to chemically retard selected radionuclides. }\end{array}$ \\
\hline $\begin{array}{l}\text { Leachate } \\
\text { Collection System }\end{array}$ & $\begin{array}{l}\text { - Granular Filter } \\
\text { - Geotextile Filter Fabric } \\
\text { - Geonet and/or } \\
\text { Gravel/Sand } \\
\text { - Perforated Collection } \\
\text { Pipes } \\
\text { - Geotextile Protective } \\
\text { Fabric }\end{array}$ & $\begin{array}{l}\text { The primary functions of the leachate collection system in conjunction with the underlying primary liner } \\
\text { are to remove leachate from the landfill and prevent the build-up of leachate on the primary liner thus } \\
\text { minimizing leachate migration to the leak detection system during the operation and institutional control } \\
\text { periods. The granular filter and geotextile filter fabric serve to minimize migration of overlying materials } \\
\text { into the geonet and/or gravel/sand thus minimizing the potential for clogging. The geonet and/or } \\
\text { gravel/sand along with the perforated collection pipes serve the primary leachate collection function. The } \\
\text { geotextile protective fabric serves to protect the underlying geomembrane from puncture or tear during } \\
\text { placement of the overlying geonet and/or gravel/sand. The leachate collection system can also serve as a } \\
\text { source depletion mechanism if the leachate is not returned to the disposal facility. }\end{array}$ \\
\hline Primary Liner & $\begin{array}{l}\text { - Geomembrane } \\
\text { (typically high density } \\
\text { polyethylene (HDPE)) } \\
\text { - Geosynthetic Clay Liner } \\
\text { (GCL) }\end{array}$ & $\begin{array}{l}\text { The primary function of the primary liner in conjunction with the overlying leachate collection system is to } \\
\text { remove leachate from the landfill and prevent the build-up of leachate on the primary liner thus minimizing } \\
\text { leachate migration to the leak detection system during the operation and institutional control periods. } \\
\text { While active operation of the leachate collection system is not typically planned beyond the institutional } \\
\text { control period, the primary liner will continue to help minimize leachate migration to the leak detection } \\
\text { system after the institutional control period. Typically a composite hydraulic barrier is utilized consisting } \\
\text { of a geomembrane underlain by a GCL. Geomembranes have a very low equivalent hydraulic conductivity } \\
\text { and most leachate transport through a geomembrane occurs through holes in the geomembrane. The GCL } \\
\text { serves to hydraulically plug any geomembrane holes that exist after construction or may develop over time. } \\
\text { The geomembrane serves to separate and protect the GCL from the impacts of the leachate. Together the } \\
\text { geomembrane and GCL form a composite barrier to leachate migration to the leak detection system. }\end{array}$ \\
\hline $\begin{array}{l}\text { Leak Detection } \\
\text { System }\end{array}$ & $\begin{array}{l}\text { - Granular Filter } \\
\text { - Geotextile Filter Fabric } \\
\text { - Geonet and/or } \\
\text { Gravel/Sand } \\
\text { - Leak Detection Piping } \\
\text { - Geotextile Protective } \\
\text { Fabric }\end{array}$ & $\begin{array}{l}\text { The primary function of the leak detection system in conjunction with the underlying secondary liner is to } \\
\text { detect the migration of leachate from the leachate collection system through the primary liner to the leak } \\
\text { detection system during the operation and institutional control periods. The granular filter and/or } \\
\text { geotextile filter fabric serve to minimize migration of overlying materials into the geonet and/or } \\
\text { gravel/sand thus minimizing the potential for clogging. The geonet and/or gravel/sand along with the leak } \\
\text { detection piping serve the primary leak detection function. The geotextile protective fabric serves to } \\
\text { protect the underlying geomembrane from puncture or tear during placement of the overlying geonet and/or } \\
\text { gravel/sand. }\end{array}$ \\
\hline
\end{tabular}




\begin{tabular}{|l|l|l|}
\hline \multicolumn{1}{|c|}{ Layer } & Potential Subcomponents & \multicolumn{1}{c|}{ Function } \\
\hline Secondary Liner & $\begin{array}{l}\text { - Geomembrane } \\
\text { (typically HDPE) } \\
\text { - Geosynthetic Clay Liner } \\
\text { (GCL) }\end{array}$ & $\begin{array}{l}\text { The primary function of the secondary liner in conjunction with the overlying leak detection system is to } \\
\text { detect the migration of leachate from the leachate collection system through the primary liner to the leak } \\
\text { detection system during the operation and institutional control periods. While active operation of the leak } \\
\text { detection system is not typically planned beyond the institutional control period, the secondary liner will } \\
\text { (CCL) }\end{array}$ \\
$\begin{array}{ll}\text { continue to help minimize leachate migration out of the landfill to the environment after the institutional } \\
\text { control period. Typically a composite hydraulic barrier is utilized consisting of a geomembrane underlain } \\
\text { by either a GCL and/or CCL. Geomembranes have a very low equivalent hydraulic conductivity and most } \\
\text { leachate transport through a geomembrane occurs through holes in the geomembrane. The GCL and/or } \\
\text { CCL serve to hydraulically plug any geomembrane holes that exist after construction or may develop over } \\
\text { time. The geomembrane serves to separate and protect the GCL and/or CCL from the impacts of the } \\
\text { leachate. Together the geomembrane and GCL and/or CCL form a composite barrier to leachate migration } \\
\text { out of the landfill to the environment. }\end{array}$ \\
\hline
\end{tabular}




\subsection{Factors Influencing Evolution of Covers and Liners}

Over time On-Site Disposal Cells (OSDCs) evolve due to changes associated with the cover system, waste zone, liner system, and the environmental setting. Evolution of the cover and liner systems in large part can be tied to the degradation mechanisms associated with individual system components or layers. Tables 8-1 and 8-2, respectively, address potential degradation mechanisms associated with individual cover and liner layers. The degradation mechanisms have been divided into the following three primary categories:

- Degradation mechanisms that should be addressed, if applicable to the site-specific circumstances, within the assessment to meet DOE Order 435.1 are highlighted in yellow.

- Degradation mechanisms that should be adequately addressed during the design process, such that they typically do not need to be considered within the assessment to meet DOE Order 435.1 are highlighted in blue. In particular the use of a biointrusion barrier and composite barrier (i.e. HDPE geomembrane overlying GCL and/or CCL) preclude many potential degradation mechanisms.

- Degradation mechanisms that can typically be discounted because of lack of significance for the assessment to meet DOE Order 435.1 are highlighted in green.

Degradation mechanisms that are not highlighted tend to be less significant, in general, but may need to be considered depending upon site-specific circumstances.

Table 8-1 includes the following cover degradation mechanisms that should be addressed within the PA, if applicable to the site-specific circumstances:

- Waste Layer Subsidence,

- Erosion of the ET layer,

- Pluggage of the drainage layer including oxidation followed by tearing of geotextile filter fabrics,

- HDPE geomembrane antioxidant depletion, thermal oxidation, and tensile stress cracking,

- GCL divalent cation exchange, and

- CCL divalent cation exchange, if sodium bentonite is utilized.

While the cover can be designed to preclude GCL and CCL desiccation, root penetration, and burrowing animals, they are well known degradation mechanisms, which should be addressed in terms of the design features incorporated to prevent such degradation.

Table 8-2 provides a list of liner degradation mechanisms that should be addressed, if applicable to the site-specific circumstances, within the PA:

- Pluggage of leachate collection system including oxidation followed by tearing of geotextile filter fabrics,

- Pluggage of the leachate collection system if operation is assumed to extend beyond the 100-year institutional control period,

- HDPE geomembrane antioxidant depletion, thermal oxidation, and tensile stress cracking,

- GCL divalent cation exchange, and

- CCL divalent cation exchange, if sodium bentonite is utilized.

The extent to which the evolution of cover and liner systems is taken into account by considering the degradation of individual layers and justified within PAs depends upon the extent to which credit must be 
taken for the performance of these layers within the cover and liner systems within the PA. The need to justify and take into account individual layer degradation generally diminishes as the layer becomes a defense-in-depth component for which little credit is given within the PA relative to reducing contaminant release out of the disposal facility (a caveat must be made for potential counter-intuitive results discussed in Section 2.2, Timing Considerations for Covers, Liners and System Performance).

NOTE: In some climatic regimes, a rock side slope severely limits evaporation and accumulated moisture can encourage the invasion of deep-rooted plants. 
Table 8-1. Potential Cover Layer Degradation Mechanisms.

\begin{tabular}{|c|c|c|}
\hline Cover Layers & Potential Degradation Mechanisms & Comments \\
\hline \multirow[t]{4}{*}{ Cover System Overall } & Waste Layer Subsidence & $\begin{array}{l}\text { If applicable, the impact of waste layer subsidence should be addressed as a } \\
\text { degradation mechanism. It is dependent upon the waste forms and containers, if used. } \\
\text { Waste forms and containers that result in the presence of significant void space within } \\
\text { the waste zone can result in collapse of the cover once sufficient degradation of the } \\
\text { waste forms and containers occurs (such as corrosion of metal containers). } \\
\text { Uncontainerized bulk waste forms, subject to biodegradation or corrosion, can lead to } \\
\text { potential subsidence as well. }\end{array}$ \\
\hline & $\begin{array}{llll}\begin{array}{l}\text { Pedogenesis } \\
\text { evolution) }\end{array} & \text { soil } & \text { formation } & \text { and } \\
\end{array}$ & $\begin{array}{l}\text { Pedogenic processes include erosion, root penetration, freeze-thaw, desiccation (wet- } \\
\text { dry cycles), burrowing animals, mineralogical changes, weathering (dissolution), } \\
\text { pluggage (siltation, colloidal clay migration, root penetration), and divalent cation } \\
\left(\mathrm{Ca}^{+2}, \mathrm{Mg}^{+2} \text {, etc.) processes discussed below in association with specific cover system }\right. \\
\text { layers. }\end{array}$ \\
\hline & Static loading induced settlement & $\begin{array}{l}\text { Static loading induced settlement should be appropriately addressed during the design } \\
\text { process. It is dependent upon the site-specific geology. Uniform settlement is } \\
\text { generally not of concern. Significant differential settlement could be of concern. }\end{array}$ \\
\hline & $\begin{array}{l}\text { Seismic induced degradation (liquefaction } \\
\text { and subsequent settlement, slope } \\
\text { instability, lateral spread, direct rupture } \\
\text { due to faulting) }\end{array}$ & $\begin{array}{l}\text { The potential for seismic induced degradation should be appropriately addressed } \\
\text { during the design process. It is dependent upon site-specific geology and seismic } \\
\text { conditions (frequency and magnitude). }\end{array}$ \\
\hline \multirow{3}{*}{$\begin{array}{l}\text { Evapotranspiration (ET) } \\
\text { Layer (vegetation, top } \\
\text { soil, soil, and capillary } \\
\text { break) }\end{array}$} & Erosion & $\begin{array}{l}\text { Erosion should be addressed as a degradation mechanism, because it can result in a } \\
\text { decrease in the water storage capacity of the ET layers as well as potential thinning of } \\
\text { the biointrusion layer. }\end{array}$ \\
\hline & Vegetative succession & $\begin{array}{l}\text { It can typically be assumed that the initial vegetation planted at cover construction is } \\
\text { maintained during the institutional control period. However after maintenance of the } \\
\text { initial vegetation has been discontinued, natural vegetative succession will begin. } \\
\text { Natural vegetative succession is a site-specific process that proceeds through a series } \\
\text { of successional species and finally to a climax species that dominates the site, unless it } \\
\text { is destroyed through drought, disease, fire, or other biological processes. Vegetative } \\
\text { succession in relation to cover degradation can primarily affect the rate of } \\
\text { evapotranspiration and the depth of root penetration. The potential impact of } \\
\text { vegetative succession should be considered on a site-specific basis as to whether it will } \\
\text { significantly change the rate of evapotranspiration or result in more damage caused by } \\
\text { root penetration. }\end{array}$ \\
\hline & $\begin{array}{l}\text { Vegetative stressors (droughts, disease, } \\
\text { fire, and biological) }\end{array}$ & $\begin{array}{l}\text { Vegetative stressors can result in temporary increases in erosion rates; and could be } \\
\text { discussed in a qualitative sense. In addition, vegetative stressors can have a major, } \\
\text { temporary adverse impact on overall barrier water loss via plant transpiration. }\end{array}$ \\
\hline
\end{tabular}




\begin{tabular}{|c|c|c|}
\hline Cover Layers & Potential Degradation Mechanisms & Comments \\
\hline & $\begin{array}{l}\text { Preferential flow path development } \\
\text { through soil pedogenesis (i.e., root } \\
\text { penetration, freeze-thaw, desiccation } \\
\text { (wet-dry cycles), burrowing animals and } \\
\text { mineralogical changes) }\end{array}$ & $\begin{array}{l}\text { Generally the development of preferential flow paths is only a concern for ET covers } \\
\text { that do not contain underlying lateral drainage and barrier layers. However, freeze- } \\
\text { thaw can result in accelerated surface erosion. Lateral flow from sources outside of the } \\
\text { disposal cell can also occur (natural capillary barriers). Evapotranspiration layers } \\
\text { consisting predominantly of silt materials rather than clays are less susceptible to the } \\
\text { development of preferential flow paths. }\end{array}$ \\
\hline \multirow[t]{2}{*}{$\begin{array}{l}\text { Biointrusion Layer } \\
\text { (cobbles or rip rap) }\end{array}$} & Weathering (Dissolution) & $\begin{array}{l}\text { Weathering (dissolution) of the biointrusion cobbles or rip rap should be appropriately } \\
\text { addressed during the design process by selecting durable materials based upon } \\
\text { standard tests. }\end{array}$ \\
\hline & Physical Stability & $\begin{array}{l}\text { The physical stability of the biointrusion cobbles or rip rap should be appropriately } \\
\text { addressed during the design process by sizing them for stability. }\end{array}$ \\
\hline Geotextile Filter Fabric & Oxidation followed by tearing & $\begin{array}{l}\text { Oxidation followed by tearing of the geotextile filter fabric should be addressed as a } \\
\text { potential degradation mechanism associated with geonets at least in terms of a } \\
\text { sensitivity analysis. Very little information is currently available regarding the } \\
\text { degradation and longevity of geotextile filter fabrics. It is thought that their } \\
\text { degradation would be similar to that of geomembranes, but at a faster rate due to their } \\
\text { greater surface area. Assumptions can be made based upon geomembrane longevity. }\end{array}$ \\
\hline $\begin{array}{l}\text { Drainage Layer (Geonet } \\
\text { and/or Gravel/Sand) }\end{array}$ & Pluggage & $\begin{array}{l}\text { Pluggage of the drainage layer should be addressed as a potential degradation } \\
\text { mechanism at least in terms of a sensitivity analysis. Very little information is } \\
\text { currently available regarding the degradation and longevity of Geonet and gravel/sand } \\
\text { drainage layers. Possible degradation mechanisms that may result in pluggage of } \\
\text { cover drainage layers include siltation, colloidal clay migration, and root penetration. } \\
\text { The longevity of Geonets is basically tied to the longevity of its geotextile filter fabric } \\
\text { (see discussion above) which prevents siltation as long as it lasts. Granular filters and } \\
\text { geotextile filter fabrics (see discussion above) can be used to prevent siltation of } \\
\text { gravel/sand drainage layers. The potential for colloidal clay to migrate into and then } \\
\text { deposit within gravel/sand drainage layers is highly dependent upon the clay } \\
\text { mineralogy and the local geochemical conditions. At any one time root penetration } \\
\text { should only impact a small volume of the drainage layer due to its typical depth and } \\
\text { can therefore typically be ignored. Due to the uncertainties associated with drainage } \\
\text { layer longevity the following types of assumptions have been made: } \\
\text { - Geonets have been assumed to remain functional until its geotextile filter fabric } \\
\text { (see discussion above) has been assumed to have degraded. } \\
\text { - Gravel/sand drainage layers have been assumed to remain functional for some } \\
\text { period of time after which a reduction in saturated hydraulic conductivity (such as } \\
\text { by a factor of ten) is assumed to occur. } \\
\text { - Assumptions regarding colloidal clay deposit within gravel/sand drainage layers } \\
\text { have been made and related to reductions in saturated hydraulic conductivity. }\end{array}$ \\
\hline
\end{tabular}




\begin{tabular}{|c|c|c|}
\hline Cover Layers & Potential Degradation Mechanisms & Comments \\
\hline $\begin{array}{l}\text { Geotextile Protective } \\
\text { Fabric }\end{array}$ & Oxidation followed by tearing & $\begin{array}{l}\text { The geotextile protective fabric serves to protect the underlying geomembrane from } \\
\text { puncture or tear during construction. As such its required service life is minimal and it } \\
\text { should therefore fully perform its required function. Therefore consideration of the } \\
\text { geotextile protective fabrics degradation is not required in order to evaluate the overall } \\
\text { functionality of the cover. }\end{array}$ \\
\hline \multirow[t]{5}{*}{$\begin{array}{l}\text { Geomembrane (typically } \\
\text { High Density } \\
\text { Polyethylene (HDPE)) }\end{array}$} & Antioxidant depletion & $\begin{array}{l}\text { Antioxidant depletion of HDPE geomembranes should be addressed as a degradation } \\
\text { mechanism. While present antioxidants prevent thermal oxidation. Depletion occurs } \\
\text { due to diffusion (primary) and oxidative consumption (secondary). The rate is } \\
\text { dependent upon temperature and the surrounding media (leachate }>\text { water }>\text { air; fluid } \\
\text { emersion }>\text { porous media). }\end{array}$ \\
\hline & Thermal oxidation & $\begin{array}{l}\text { Thermal oxidation of HDPE geomembranes should be addressed as a degradation } \\
\text { mechanism. If oxygen is present, thermal oxidation will begin after antioxidants are } \\
\text { depleted and the induction period is over. It causes polymer main-chain scission (bond } \\
\text { breaking) and over time results in mechanical property degradation and embrittlement. } \\
\text { If total absorbed dose in the summary of Appendix B is exceeded, this may need to be } \\
\text { considered (see discussion on high energy irradiation below). }\end{array}$ \\
\hline & Tensile stress cracking & $\begin{array}{l}\text { Tensile stress cracking of HDPE geomembranes should be addressed as a degradation } \\
\text { mechanism. As thermal oxidation proceeds tensile stress cracking can occur as a } \\
\text { ductile tensile failure based upon the geomembrane tensile break strength or brittle } \\
\text { stress cracking based upon geomembrane stress crack resistance (SCR) due to the } \\
\text { applied tensile stress on the geomembrane. As long as the geomembrane is not } \\
\text { subjected to significant tensile or shear stresses, it should not fragment and } \\
\text { disintegrate, but it should remain intact. Differential settlement and geomembrane } \\
\text { downdrag by waste settlement on the side slopes are most likely to produce stresses } \\
\text { that result in tensile stress cracking. }\end{array}$ \\
\hline & Ultraviolet (UV) radiation & $\begin{array}{l}\text { Due to the carbon black content of typical HDPE geomembranes, UV exposure is not a } \\
\text { significant degradation mechanism for the short-term exposures associated with cover } \\
\text { construction, where the geomembrane is covered in a timely manner. Therefore this } \\
\text { degradation mechanism can be typically ignored. }\end{array}$ \\
\hline & High energy irradiation & $\begin{array}{l}\text { At dose rates below } 5000 \text { Rad/hr significant mechanical property degradation does not } \\
\text { occur below a total absorbed dose of } 2.5 \text { MRad. For typical low-level waste disposal } \\
\text { associated with CERCLA cells this total absorbed dose would not likely be reached } \\
\text { due to the relatively low inventory and shielding provided by underlying materials (i.e. } \\
\text { CCL, foundation layer, and waste itself). Therefore this degradation mechanism can } \\
\text { be typically ignored. Appendix B provides additional information regarding the } \\
\text { impact of high energy irradiation on HDPE geomembranes. }\end{array}$ \\
\hline
\end{tabular}




\begin{tabular}{|c|c|c|}
\hline \multirow[t]{4}{*}{ Cover Layers } & Potential Degradation Mechanisms & Comments \\
\hline & Root penetration & $\begin{array}{l}\text { Intact HDPE geomembranes are impervious to roots. Roots can only penetrate HDPE } \\
\text { geomembranes in location where holes in the geomembrane have already formed due } \\
\text { to other modes of HDPE degradation. Therefore this potential degradation mechanism } \\
\text { can be typically ignored. }\end{array}$ \\
\hline & Burrowing animals & $\begin{array}{l}\text { Unprotected HDPE geomembranes are potentially vulnerable to burrowing animals; } \\
\text { however an overlying biointrusion layer can be utilized to preclude this degradation } \\
\text { mechanism. }\end{array}$ \\
\hline & Microbial & $\begin{array}{l}\text { Evidence to date indicates HDPE geomembranes are insensitive to microbial } \\
\text { degradation, due their high-molecular-weight and density. Therefore this potential } \\
\text { degradation mechanism can be ignored. }\end{array}$ \\
\hline \multirow[t]{7}{*}{$\begin{array}{l}\text { Geosynthetic Clay Layer } \\
\text { (GCL) }\end{array}$} & Slope stability & $\begin{array}{l}\text { GCL slope stability should be appropriately addressed during the design process. } \\
\text { GCLs without internal reinforcement can generally be safely placed on up to } 10 \% \\
\text { slopes. }\end{array}$ \\
\hline & Freeze-thaw cycles & $\begin{array}{l}\text { Freeze-thaw cycles should be precluded as a potential degradation mechanism during } \\
\text { the design process by placing the GCL below the site-specific maximum frost depth. }\end{array}$ \\
\hline & Natural weathering (dissolution) & $\begin{array}{l}\text { The clay typically used within GCLs is sodium bentonite. Within the } 1,000 \text { year time } \\
\text { frame of concern natural weathering of sodium bentonite would not be a degradation } \\
\text { mechanism of concern. }\end{array}$ \\
\hline & Divalent cations $\left(\mathrm{Ca}^{+2}, \mathrm{Mg}^{+2}\right.$, etc. $)$ & $\begin{array}{l}\text { GCLs containing sodium bentonite are vulnerable to saturated hydraulic conductivity } \\
\text { increases due to cation exchange of the sodium with divalent cations such as calcium } \\
\text { and magnesium. Infiltrating water containing } 100 \mathrm{~s} \text { of } \mathrm{mg} / \mathrm{L} \mathrm{Ca}^{+2} \text { can result in a ten- } \\
\text { fold increase in saturated hydraulic conductivity. Infiltrating water containing } 1,000 \text { s } \\
\text { of } \mathrm{mg} / \mathrm{L} \mathrm{Ca}{ }^{+2} \text { can result in a thousand-fold increase in saturated hydraulic conductivity. } \\
\text { Even if an overlying HDPE geomembrane is utilized, the underlying GCL can be } \\
\text { contacted with infiltrating water through the holes in the geomembrane. Therefore } \\
\text { GCL degradation by divalent cations should be addressed as a degradation mechanism. }\end{array}$ \\
\hline & Desiccation (wet-dry cycles) & $\begin{array}{l}\text { Unprotected GCLs are vulnerable to desiccation and a subsequent increase in saturated } \\
\text { hydraulic conductivity; however an overlying HDPE geomembrane can be utilized to } \\
\text { preclude this degradation mechanism for as long as the geomembrane remains } \\
\text { essentially intact. This assumes that the region beneath the GCL remains relatively } \\
\text { moist. The potential for a material beneath the GCL to dry and create suction pressure } \\
\text { that could dry the GCL should be addressed, however, this is considered relatively } \\
\text { unlikely. }\end{array}$ \\
\hline & Root penetration & $\begin{array}{l}\text { Unprotected GCLs are potentially vulnerable to root penetration; however an } \\
\text { overlying HDPE geomembrane can be utilized to preclude this degradation mechanism } \\
\text { for as long as the geomembrane remains essentially intact. }\end{array}$ \\
\hline & Burrowing animals & $\begin{array}{l}\text { Unprotected GCLs are potentially vulnerable to burrowing animals; however an } \\
\text { overlying biointrusion layer can be utilized to preclude this degradation mechanism. }\end{array}$ \\
\hline Compacted Clay Layer & Slope stability & CCL slope stability should be appropriately addressed during the design process. \\
\hline
\end{tabular}




\begin{tabular}{|l|l|l|}
\hline \multicolumn{1}{|c|}{ Cover Layers } & Potential Degradation Mechanisms & \multicolumn{1}{c|}{ Comments } \\
\hline (CCL) & Freeze-thaw cycles & $\begin{array}{l}\text { Freeze-thaw cycles should be precluded as a potential degradation mechanism during } \\
\text { the design process by placing the CCL below the site-specific maximum frost depth. }\end{array}$ \\
\cline { 2 - 3 } & Natural weathering (dissolution) & $\begin{array}{l}\text { Natural weathering of the clay fraction of CCLs is dependent upon the clay } \\
\text { mineralogy. However within the 1,000 year time frame of concern natural weathering } \\
\text { of typical clays (i.e. kaolinite, illite, and sodium bentonite) would not be a degradation } \\
\text { mechanism of concern. }\end{array}$ \\
\cline { 2 - 3 } & $\begin{array}{l}\text { Saturated hydraulic conductivity increases due to cation exchange with divalent } \\
\text { cations such as calcium and magnesium is dependent upon the clay mineralogy. The } \\
\text { presence of divalent cations has very little impact upon kaolinite or illite. However as } \\
\text { outlined above the presence of divalent cations has a significant impact upon the } \\
\text { saturated hydraulic conductivity of sodium bentonite. }\end{array}$ \\
\cline { 2 - 3 } & $\begin{array}{l}\text { Unprotected CCLs are vulnerable to desiccation; however an overlying HDPE } \\
\text { geomembrane can be utilized to preclude this degradation mechanism for as long as } \\
\text { the geomembrane remains essentially intact. This assumes that the region beneath the } \\
\text { CCL remains relatively moist. The potential for a material beneath the CCL to dry and } \\
\text { create suction pressure that could dry the CCL should be addressed, however, this is } \\
\text { considered relatively unlikely. }\end{array}$ \\
\cline { 2 - 3 } & $\begin{array}{l}\text { Unprotected CCLs are potentially vulnerable to root penetration; however an overlying } \\
\text { HDPE geomembrane can be utilized to preclude this degradation mechanism for as } \\
\text { long as the geomembrane remains essentially intact. }\end{array}$ \\
\hline & $\begin{array}{l}\text { Unprotected CCLs are potentially vulnerable to burrowing animals; however an } \\
\text { overlying biointrusion layer can be utilized to preclude this degradation mechanism. }\end{array}$ \\
\hline
\end{tabular}

Degradation mechanisms that should be addressed, if applicable to the site-specific circumstances, within the PA are highlighted in yellow.

Degradation mechanisms that should be adequately addressed during the design process, so that it does not need to be considered within the PA are highlighted in blue.

Degradation mechanisms that can typically be discounted because of lack of significance by the PA are highlighted in green.

Degradation mechanism that is probably insignificant depending upon site-specific circumstances. 
Table 8-2. Potential Liner Materials Degradation Mechanisms.

\begin{tabular}{|c|c|c|}
\hline Liner Layers & Potential Degradation Mechanisms & Comments \\
\hline \multirow[t]{2}{*}{ Liner System Overall } & Static loading induced settlement & $\begin{array}{l}\text { Static loading induced settlement should be appropriately addressed during the design } \\
\text { process. It is dependent upon the site-specific geology. Uniform settlement is } \\
\text { generally not of concern. Significant differential settlement could be of concern. }\end{array}$ \\
\hline & $\begin{array}{l}\text { Seismic induced degradation (liquefaction } \\
\text { and subsequent settlement, slope } \\
\text { instability, lateral spread, direct rupture } \\
\text { due to faulting) }\end{array}$ & $\begin{array}{l}\text { The potential for seismic induced degradation should be appropriately addressed } \\
\text { during the design process. It is dependent upon site-specific geology and seismic } \\
\text { conditions (frequency and magnitude). }\end{array}$ \\
\hline Geotextile Filter Fabric & Oxidation followed by tearing & $\begin{array}{l}\text { Oxidation followed by tearing of the geotextile filter fabric should be addressed as a } \\
\text { potential degradation mechanism associated with Geonet at least in terms of a } \\
\text { sensitivity analysis. Very little information is currently available regarding the } \\
\text { degradation and longevity of geotextile filter fabrics. It is thought that their } \\
\text { degradation would be similar to that of geomembranes, but at a faster rate due to their } \\
\text { greater surface area. Assumptions can be made based upon geomembrane longevity. }\end{array}$ \\
\hline $\begin{array}{l}\text { Leachate Collection and } \\
\text { Leak Detection Systems } \\
\text { (Geonet and/or } \\
\text { Gravel/Sand }\end{array}$ & $\begin{array}{l}\text { Pluggage } \\
\text { (If operation is assumed to extend beyond } \\
\text { the 100-year institutional control period, } \\
\text { then pluggage should be addressed as a } \\
\text { potential degradation mechanism at least } \\
\text { in terms of a sensitivity analysis.) }\end{array}$ & $\begin{array}{l}\text { Operations of the leachate collection and leak detection systems are typically only } \\
\text { planned during the operation and institutional control periods. Therefore it is less } \\
\text { important to address degradation of the leachate collection and leak detection systems } \\
\text { than for the cover's lateral drainage layer. However if operations of the leachate } \\
\text { collection and/or leak detection systems are planned to extend beyond the institutional } \\
\text { control period, pluggage of the leachate collection and leak detection systems should } \\
\text { be addressed as a potential degradation mechanism at least in terms of a sensitivity } \\
\text { analysis. Very little information is currently available regarding the degradation and } \\
\text { longevity of Geonet and gravel/sand used in leachate collection or leak detection } \\
\text { systems. Possible degradation mechanisms that may result in pluggage of leachate } \\
\text { collection and leak detection systems include siltation, colloidal clay migration, and } \\
\text { microbial fouling. The longevity of Geonets is basically tied to the longevity of its } \\
\text { geotextile filter fabric (see discussion above) which prevents siltation as long as it } \\
\text { lasts. Granular filters and geotextile filter fabrics (see discussion above) can be used to } \\
\text { prevent siltation of gravel/sand drainage layers. The potential for colloidal clay to } \\
\text { migrate into and then deposit within gravel/sand drainage layers is highly dependent } \\
\text { upon the clay mineralogy and the local geochemical conditions. Microbial fouling is a } \\
\text { significant concern for sanitary landfills that include putrescible waste; but it is } \\
\text { relatively unimportant for low-level waste landfills that generally do not contain } \\
\text { putrescible waste (organic wastes typically found in low-level waste landfills (e.g. } \\
\text { wood, cardboard, paper, plastics) are not readily degradable). }\end{array}$ \\
\hline
\end{tabular}




\begin{tabular}{|c|c|c|}
\hline Liner Layers & Potential Degradation Mechanisms & Comments \\
\hline $\begin{array}{l}\text { Geotextile Protective } \\
\text { Fabric }\end{array}$ & Oxidation followed by tearing & $\begin{array}{l}\text { The geotextile protective fabric serves to protect the underlying geomembrane from } \\
\text { puncture or tear during construction. As such its required service life is minimal and it } \\
\text { should therefore fully perform its required function. Therefore consideration of the } \\
\text { geotextile protective fabrics degradation is not required in order to evaluate the overall } \\
\text { functionality of the cover. }\end{array}$ \\
\hline \multirow[t]{4}{*}{$\begin{array}{l}\text { Geomembrane (typically } \\
\text { High Density } \\
\text { Polyethylene (HDPE)) }\end{array}$} & Antioxidant depletion & $\begin{array}{l}\text { Antioxidant depletion of HDPE geomembranes should be addressed as a degradation } \\
\text { mechanism. While present antioxidants prevent thermal oxidation. Depletion occurs } \\
\text { due to diffusion (primary) and oxidative consumption (secondary). The rate is } \\
\text { dependent upon temperature and the surrounding media (leachate }>\text { water }>\text { air; fluid } \\
\text { emersion }>\text { porous media). }\end{array}$ \\
\hline & Thermal oxidation & $\begin{array}{l}\text { Thermal oxidation of HDPE geomembranes should be addressed as a degradation } \\
\text { mechanism. If oxygen is present, thermal oxidation will begin after antioxidants are } \\
\text { depleted and the induction period is over. It causes polymer main-chain scission (bond } \\
\text { breaking) and over time results in mechanical property degradation and embrittlement. } \\
\text { If total absorbed dose in the summary of Appendix B is exceeded, this may need to be } \\
\text { considered (see discussion on high energy irradiation below). }\end{array}$ \\
\hline & Tensile stress cracking & $\begin{array}{l}\text { Tensile stress cracking of HDPE geomembranes should be addressed as a degradation } \\
\text { mechanism. As thermal oxidation proceeds tensile stress cracking can occur as a } \\
\text { ductile tensile failure based upon the geomembrane tensile break strength or brittle } \\
\text { stress cracking based upon geomembrane stress crack resistance (SCR) due to the } \\
\text { applied tensile stress on the geomembrane. As long as the geomembrane is not } \\
\text { subjected to significant tensile or shear stresses, it should not fragment and } \\
\text { disintegrate, but it should remain intact. Differential settlement and geomembrane } \\
\text { downdrag by waste settlement on the side slopes are most likely to produce stresses } \\
\text { that result in tensile stress cracking. }\end{array}$ \\
\hline & Ultraviolet (UV) radiation & $\begin{array}{l}\text { Due to the carbon black content of typical HDPE geomembranes, UV exposure is not a } \\
\text { significant degradation mechanism for the short-term exposures associated with liner } \\
\text { construction, where the geomembrane is covered in a timely manner. Therefore this } \\
\text { degradation mechanism can be typically ignored. }\end{array}$ \\
\hline
\end{tabular}




\begin{tabular}{|c|c|c|}
\hline \multirow[t]{4}{*}{ Liner Layers } & Potential Degradation Mechanisms & Comments \\
\hline & High energy irradiation & $\begin{array}{l}\text { At dose rates below } 5000 \text { Rad/hr significant mechanical property degradation does not } \\
\text { occur below a total absorbed dose of } 2.5 \text { MRad. For typical low-level waste disposal } \\
\text { associated with CERCLA cells this total absorbed dose would not likely be reached } \\
\text { due to the relatively low inventory and shielding provided by overlying materials (i.e. } \\
\text { waste itself, protective layer, and leachate collection layer). Therefore this degradation } \\
\text { mechanism can be typically screened using upper bound assumptions regarding } \\
\text { concentrations and dose rates for the expected wastes. The relatively low } \\
\text { concentrations and distance between the waste and the liner material generally lead to } \\
\text { this mechanism not being a concern. This can also be controlled through waste } \\
\text { acceptance criteria and operating procedures to maintain distance between any higher } \\
\text { activity waste and the liner. }\end{array}$ \\
\hline & Chemical Compatibility & $\begin{array}{l}\text { High concentrations of organic solvents, salts, or other highly reactive chemicals can } \\
\text { result in polymeric chain scission, bond breaking within the polymer structure of } \\
\text { HDPE, or increase the permeability of the liner materials. HDPE membranes can } \\
\text { deteriorate from contact with certain leachates, resulting in a decrease of elongation at } \\
\text { failure, an increase in modulus of elasticity, a decrease in the stress at failure, and a } \\
\text { loss of ductility. For wastes disposed in DOE disposal facilities, the concentrations in } \\
\text { the leachate are typically not sufficient to cause significant deterioration. Typically, } \\
\text { this mechanism can be screened based on assuming upper bound concentrations in } \\
\text { leachate and comparing those to threshold concentrations that would be expected to } \\
\text { result in impacts. }\end{array}$ \\
\hline & Microbial & $\begin{array}{l}\text { Evidence to date indicates HDPE geomembranes are insensitive to microbial } \\
\text { degradation, due their high-molecular-weight and density. Therefore this potential } \\
\text { degradation mechanism can be ignored. }\end{array}$ \\
\hline \multirow[t]{3}{*}{$\begin{array}{l}\text { Geosynthetic Clay Layer } \\
(\text { GCL })^{1}\end{array}$} & Slope stability & $\begin{array}{l}\text { GCL slope stability should be appropriately addressed during the design process. } \\
\text { GCLs without internal reinforcement can generally be safely placed on up to } 10 \% \\
\text { slopes. }\end{array}$ \\
\hline & Freeze-thaw cycles & $\begin{array}{l}\text { Freeze-thaw cycles should only be a potential concern for the GCL during the } \\
\text { operations period prior to waste and cover placement. Freeze-thaw cycles should be } \\
\text { precluded as a potential degradation mechanism during the design process by placing } \\
\text { the GCL below the site-specific maximum frost depth. }\end{array}$ \\
\hline & Natural weathering (dissolution) & $\begin{array}{l}\text { The clay typically used within GCLs is sodium bentonite. Within the } 1,000 \text { year time } \\
\text { frame of concern natural weathering of sodium bentonite would not be a degradation } \\
\text { mechanism of concern. }\end{array}$ \\
\hline
\end{tabular}




\begin{tabular}{|c|c|c|}
\hline Liner Layers & Potential Degradation Mechanisms & Comments \\
\hline & Divalent cations $\left(\mathrm{Ca}^{+2}, \mathrm{Mg}^{+2}\right.$, etc. $)$ & $\begin{array}{l}\text { GCLs containing sodium bentonite are vulnerable to saturated hydraulic conductivity } \\
\text { increases due to cation exchange of the sodium with divalent cations such as calcium } \\
\text { and magnesium. Leachate containing } 100 \mathrm{~s} \text { of } \mathrm{mg} / \mathrm{L} \mathrm{Ca} \mathrm{Ca}^{+2} \text { can result in a ten-fold } \\
\text { increase in saturated hydraulic conductivity. Leachate containing } 1,000 \mathrm{~s} \text { of } \mathrm{mg} / \mathrm{L} \mathrm{Ca} \mathrm{Ca}^{+2} \\
\text { can result in a thousand-fold increase in saturated hydraulic conductivity. Even if an } \\
\text { overlying HDPE geomembrane is utilized, the underlying GCL can be contacted with } \\
\text { infiltrating water through the holes in the geomembrane. Therefore GCL degradation } \\
\text { by divalent cations should be addressed as a degradation mechanism. Low-level waste } \\
\text { landfills often contain a significant amount of concrete rubble which can be a source of } \\
\mathrm{Ca}^{+2} \text {. }\end{array}$ \\
\hline & Desiccation (wet-dry cycles) & $\begin{array}{l}\text { Unprotected GCLs are vulnerable to desiccation and a subsequent increase in saturated } \\
\text { hydraulic conductivity; however an overlying HDPE geomembrane can be utilized to } \\
\text { preclude this degradation mechanism. Additionally upon waste and cover placement } \\
\text { the GCL should be significantly below the ET zone where desiccation is of most } \\
\text { concern and the additional overburden pressure would serve to heal any desiccation } \\
\text { damage. This assumes that the region beneath the GCL remains relatively moist. The } \\
\text { potential for a material beneath the GCL to dry and create suction pressure that could } \\
\text { dry the GCL should be addressed, however, this is considered relatively unlikely. }\end{array}$ \\
\hline \multirow{4}{*}{$\begin{array}{l}\text { Compacted Clay Layer } \\
(\mathrm{CCL})^{1}\end{array}$} & Slope stability & CCL slope stability should be appropriately addressed during the design process. \\
\hline & Freeze-thaw cycles & $\begin{array}{l}\text { Freeze-thaw cycles should only be a potential concern for the CCL during the } \\
\text { operations period prior to waste and cover placement. Freeze-thaw cycles should be } \\
\text { precluded as a potential degradation mechanism during the design process by placing } \\
\text { the CCL below the site-specific maximum frost depth. }\end{array}$ \\
\hline & Natural weathering (dissolution) & $\begin{array}{l}\text { Natural weathering of the clay fraction of CCLs is dependent upon the clay } \\
\text { mineralogy. However within the } 1,000 \text { year time frame of concern natural weathering } \\
\text { of typical clays (i.e. kaolinite, illite, and sodium bentonite) would not be a degradation } \\
\text { mechanism of concern. }\end{array}$ \\
\hline & Divalent cations $(\mathrm{Ca}+2, \mathrm{Mg}+2$, etc.) & $\begin{array}{l}\text { Saturated hydraulic conductivity increases due to cation exchange with divalent } \\
\text { cations such as calcium and magnesium is dependent upon the clay mineralogy. The } \\
\text { presence of divalent cations has very little impact upon kaolinite or illite. However as } \\
\text { outlined above the presence of divalent cations has a significant impact upon the } \\
\text { saturated hydraulic conductivity of sodium bentonite. }\end{array}$ \\
\hline
\end{tabular}




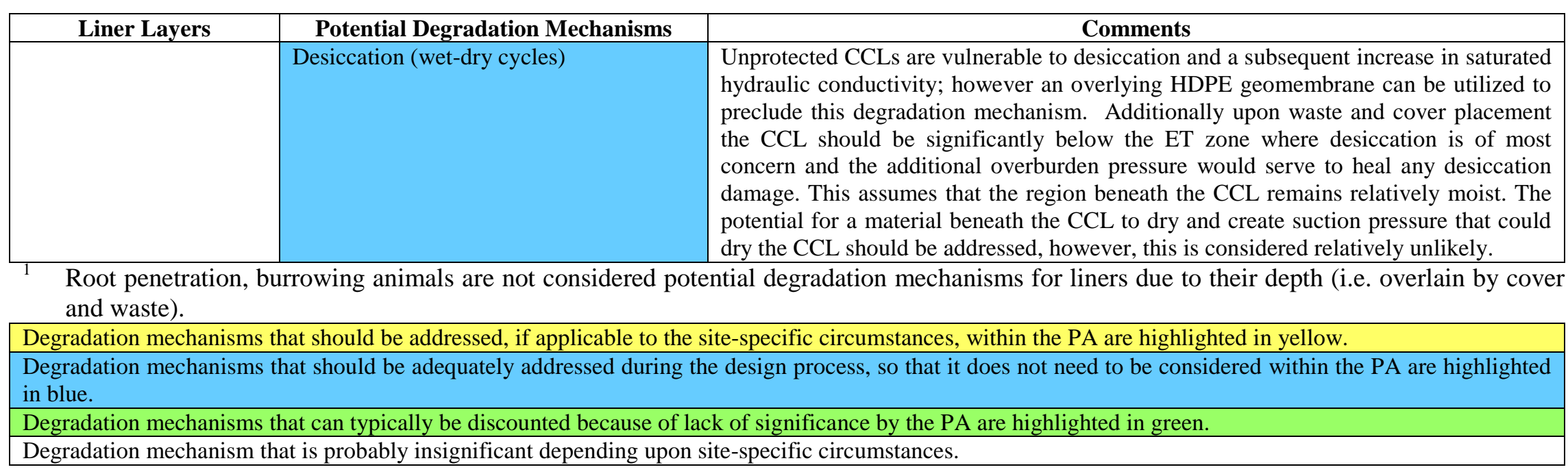


SRNL-STI-2014-00409

Revision 0

\subsection{Technical Information about Long-Term Evolution of Covers and Liners}

\subsection{Subsidence}

Whether or not subsidence needs to be addressed within a PA is site-specific. Often disposal practices will preclude subsidence by eliminating significant void volumes within the waste zone. If such practices are employed, they should be described within the PA as justification for discounting subsidence as a cover degradation mechanism. If however, waste forms and/or containers are disposed within the disposal facility that result in the presence of significant void volumes within the waste zone, the potential impact of subsidence should be addressed within the PA. This also applies to the case where waste is disposed within vaults or other structural forms that may include voids. Once sufficient degradation of the waste forms, containers, and/or structures occurs, they could collapse under the overburden pressure and result in the subsequent collapse of the overlying cover, which would result in increased infiltration to the waste zone in the area of cover collapse. Often waste forms and/or containers with significant void volumes are metal and a consideration of metal corrosion can be utilized along with static loading calculations to determine when a collapse of the waste forms and/or containers would likely occur. Vaults are typically reinforced concrete structures that may contain significant void volumes and a consideration of applicable concrete degradation can be utilized along with static loading (or seismic loading if applicable) calculations to determine when potential collapse of the vault would likely occur. Conservative assumptions regarding the timing of subsidence may also be utilized with justification.

The following are examples of subsidence considerations within PAs:

- $\quad$ The SRS F-Area Tank Farm (FTF) and H-Area Tank Farm (HTF) PAs discounted subsidence as a cover degradation mechanism by committing to completely grout all tanks, ancillary equipment with significant void volumes, and all piping greater than six inches in diameter. Six inch diameter piping and less was assumed to be of no consequence in the context of the tank farms with regards to subsidence due to the limited and dispersed distribution throughout the area of the cover (SRR 2010; SRR 2012).

- The SRS E-Area Low-Level Waste Facility (ELLWF) PA accounted for subsidence within the Slit Trenches due to the presence of large metal vessels and equipment containing significant void volume within $10 \%$ or less of the trench area. The ELLWF PA made the conservative assumption that all such vessels and equipment collapsed at the end of the 100-year institutional control period resulting in increased localized infiltration through the waste zone in $10 \%$ of the trench area (WSRC 2008).

- $\quad$ The Idaho National Laboratory (INL) Remote-Handled Low-Level (RH-LLW) Waste Disposal Facility PA provided an estimate of concrete vault longevity of greater than 1,000 years based upon degradation by carbonation. As a sensitivity case, INL assumed that $50 \%$ of the area subsided due to vault collapse at year 250 resulting in infiltration equaling precipitation (i.e. 20 $\mathrm{cm} / \mathrm{yr}$ ) (INL 2012).

- The INL CERCLA Disposal Facility (ICDF) Landfill predicted the landfill cover settlement due to consolidation and specified a final grade of $7 \%$ so that after consolidation a minimum slope of $3 \%$ would be maintained to promote surface water drainage off the cover system through its life cycle (INL 2011).

Subsidence has also been addressed in assessments using an assumption of significant increases in infiltration through the waste and/or adopting a higher than expected infiltration rate through the cover. 


\subsection{Erosion}

Erosion should be addressed as a degradation mechanism for the ET layer, because it can result in a decrease in the water storage capacity of the ET layers as their total thickness decreases over time as well as a decrease in thickness of the cover as a biobarrier. Erosion can also impact the thickness of cover assumed for an inadvertent intruder analysis. Many acceptable methods exist to estimate soil loss due to erosion such as:

- Universal Soil Loss Equation (USLE) (http://www.ars.usda.gov/Research//docs.htm?docid=10626),

- Revised Universal Soil Loss Equation, Version 2 (RUSLE2) (http://fargo.nserl.purdue.edu/rusle2_dataweb/RUSLE2_Index.htm),

- Modified Universal Soil Loss Equation (MUSLE) (http://www.nrcs.usda.gov/Internet/FSE DOCUMENTS/nrcs143 013359.pdf), and

- Various landform models have also been promoted as means of evaluating erosion over 1,000s of years.

When the NRC has been involved in PA reviews, in addition to requiring the estimation of soil loss due to erosion, they have also required a determination of the physical stability of the layer defined as the prevention of gully initiation during a Probable Maximum Precipitation (PMP) event. A PMP is defined as the theoretically greatest depth of precipitation for a given duration that is physically possible over a given storm size area at a particular geographic location. The NRC has required that such determinations be made using the calculations outlined within Abt and Johnson 1991 and Johnson 2002.

Abt and Johnson 1991 and Johnson 2002 also outline methods to establish the physical stability (defined as the prevention of any riprap movement during a PMP event) of biointrusion barriers (cobbles or rip rap), rip rap on side slopes, and rip rap on the toe of side slopes.

The following are examples of erosion considerations within PAs:

- Erosion was specifically considered in the PA for ICDF (DOE-ID 2011). Surface water and wind erosion were considered. The cover design includes the use of a mix of fine soil and pea gravel at the surface to provide protection against erosion. Surface water was addressed using MUSLE. The calculations suggested erosion of roughly two feet in 1,000 years without taking credit for the pea gravel additive. Such a conservative approach was acceptable in the case of ICDF, where the thickness of the ET layer was sufficient even with two feet of erosion. A mixture of fine grain soils and pea gravel on the surface of a cover has been demonstrated to significantly reduce erosion due to wind up to $67 \mathrm{mph}$ (Ligotke 1993).

- The design of the INL RH-LLW Disposal Facility cover design included features to minimize wind and water erosion including side slope armoring. The cover thickness was such that even considering erosion that it would remain thick enough to prevent biointrusion (INL 2012).

- The vegetative soil covers (material type, slope, and slope length) for the SRS FTF, HTF, and Saltstone Disposal Facility (SDF) PAs (SRR 2009; SRR 2010; SRR 2012) were designed to be physically stable (i.e. prevents the initiation of gullying during a PMP event) per Abt and Johnson 1991 and Johnson 2002. In addition the USLE was used to estimate soil loss due to erosion over time and the reduction in vegetative soil cover thickness over time was taken into consideration in the infiltration estimates produced from use of the Hydrologic Evaluation of Landfill Performance (HELP) model (Schroeder 1994a and 1994b). 
In addition to erosion the potential for soil pedogenesis (i.e. root penetration, desiccation (wet-dry cycles), freeze-thaw, burrowing animals, and mineralogical changes) to produce preferential flow paths within the ET layer should be considered, particularly for ET covers that do not include drainage/barrier layers as a defense-in-depth (Benson 2014).

\subsection{Cover Drainage Layer and Liner Leachate Collection System Pluggage}

Cover drainage layers typically consist of either a geonet composite and/or sand/gravel layers. A geonet composite typically consists of an extruded HDPE drainage geonet core with a non-woven filter fabric bonded to the geonet (GSE 2013). Sand/gravel drainage layers typically consist of a one-foot thick sand or gravel layer with a minimum saturated hydraulic conductivity of $1 \mathrm{E}-02 \mathrm{~cm} / \mathrm{sec}$ on a minimum three percent slope (EPA 1989).

Very little research has been conducted to date regarding potential pluggage of cover drainage layers (Jones 2010). For cover drainage layers the primary mode of potential degradation includes the transport of silt and/or colloid-sized clays from the overlying fill material and disposition of the silt and/or colloidsized clays within the cover drainage layer. Microbial fouling and pluggage of cover drainage layers is not typically of concern due to the low organic carbon content of most overlying cover materials. Siltation of the drainage layer is often minimized through the use of: 1) an overlying filter fabric; 2) a layer of finer grain-size sand above the coarser sand/gravel drainage layer; and/or 3) selecting the grain size of sand/gravel drainage layer such that the small pore throats of the sand/gravel drainage layer will 'strain out' the silt over a small distance (Jones 2010). The use of a filter fabric alone to preclude siltation over long periods of time (i.e. 100s of years) can be problematic because it can be assumed that the filter fabric will degrade and tear at some point, many years after placement. This is particularly problematic for geonet composites because the filter fabric is the sole means of preventing the migration of the overlying soil material into the geonet itself. Due to the high surface area associated with filter fabrics it can be assumed that thermal oxidation and tensile stress tearing similar to that associated with HDPE geomembranes would occur but at an accelerated rate compared to the HDPE geomembrane. Additionally root penetration can also be a means of filter fabric degradation (Phifer 2007).

Various means have been used to consider drainage layer pluggage, including:

- No pluggage and a constant saturated hydraulic conductivity of the cover drainage layer have been assumed.

- At some point in time the drainage layer has been converted from a drainage layer to a vertical percolation layer.

- Phifer and Nelson (2003) reduced the saturated hydraulic conductivity of the drainage layer over time based upon the infiltration of water containing an assumed concentration of colloid-sized clays from the overlying fill material and disposition within the drainage layer. This is likely a conservative model for a drainage layer, because no credit was taken for flushing of colloids out of the drainage system.

- WCS 2007 reduced the saturated hydraulic conductivity of the drainage layer by a factor of 10 as part of a HELP model sensitivity analysis.

Liner leachate collection system drainage layers are subject to the same degradation mechanisms as the cover drainage layer. In addition for landfills which contain a significant amount of putrescible waste, such as sanitary landfills, the leachate collection system is also subject to microbial fouling and pluggage. The presence of organic waste with high cellulose content such as wood, cardboard, and paper do not necessarily result in sufficient organic substrate to promote microbial fouling and pluggage. In any event it is typically assumed that active leachate collection and treatment only occurs for a limited time after 
closure of the landfill as the waste drains (typically only through the assumed 100-year institutional control period). After the 100-year institutional control period it is generally assumed that the leachate collection system no longer functions as an active system (at this point it can be assumed that the leachate collection system becomes a vertical percolation layer).

\subsection{HDPE Geomembrane Degradation (Antioxidant Depletion, Thermal Oxidation, and Tensile Stress Cracking)}

The primary HDPE geomembrane degradation mechanisms of significance as outlined in Tables 8-1 and 8-2 are antioxidant depletion followed by an induction period leading to thermal oxidation, which promotes tensile stress cracking due to geomembrane embrittlement and the applied tensile stress on the geomembrane. Accelerated research (i.e. testing conducted at elevated temperature) on HDPE geomembrane degradation due to antioxidant depletion, thermal oxidation, and tensile stress cracking is on-going. The research has been conducted to the point that estimates of HDPE longevity at various temperatures have been published in the literature. The following are summaries of HDPE longevity estimates based upon the research published to date. Given the uncertainty regarding specific changes in performance, it is common to use service life as a guide to consider a range of timing/changes in performance (e.g., step change, gradual failure, etc.) depending on the significance for the conclusions of the assessment. Significant research in this area is still on-going and some of the best sources of new information are also provided below.

The research to date indicates that HDPE geomembrane degradation is dependent upon the following primary factors: temperature (as temperature increases the rate of degradation increases); exposure conditions (rate of degradation is greatest in leachate > water > air; fluid emersion > porous media); and HDPE geomembrane thickness (antioxidant depletion time is essentially directly proportional to thickness). PA considerations of HDPE geomembrane longevity need to consider the implication of sitespecific conditions on the projection of HDPE geomembrane longevity. Additionally while HDPE geomembranes should have longevities on the order of 100s of years, the longevity assumptions utilized with in the PAs should be determined on a case-by-case basis through negotiation with the appropriate regulators, typically EPA and the State regulator. This is appropriate because the assumed HDPE longevity is specific to the site's climate, waste, overall facility design, current technical standards, general state of knowledge, and the regulators' technical awareness, interests, and concerns.

Koerner et al. (2011) produced the Table 9-1 lifetime prediction for non-exposed HDPE geomembranes, based upon the testing by Hsuan and Koerner (1998) and others. As seen within Table 9-1, a 446 year total predicted service life is predicted at a temperature of $20^{\circ} \mathrm{C}$.

Table 9-1. Koerner et al. (2011) Lifetime Prediction for Non-Exposed HDPE Geomembranes.

\begin{tabular}{|c|c|c|c|c|}
\hline $\begin{array}{c}\text { Temperature } \\
\left({ }^{\mathbf{}} \mathbf{C}\right)\end{array}$ & $\begin{array}{c}\text { Antioxidant } \\
\text { Depletion Period } \\
\text { (years) }\end{array}$ & $\begin{array}{c}\text { Induction } \\
\text { Period } \\
\text { (years) }\end{array}$ & $\begin{array}{c}\text { Thermal Oxidation } \\
\text { Period }^{\mathbf{1}} \\
\text { (years) }\end{array}$ & $\begin{array}{c}\text { Total Predicted } \\
\text { Service Life } \\
\text { (years) }\end{array}$ \\
\hline 20 & 208 & 30 & 208 & 446 \\
\hline 25 & 140 & 25 & 100 & 265 \\
\hline 30 & 97 & 20 & 49 & 166 \\
\hline 35 & 66 & 15 & 25 & 106 \\
\hline 40 & 46 & 10 & 13 & 69 \\
\hline
\end{tabular}

The thermal oxidation period is defined as the time it takes for the tensile properties of the HDPE to be reduced by $50 \%$. Even at this point the material still exists and functions; however its functionality may have decreased from that of initial placement. 
Mueller and Jakob (2003) conservatively estimated that under normal ambient conditions $\left(20^{\circ} \mathrm{C}\right)$ with submersion in water that the service life of HDPE geomembranes would be at least 300 years and up to 1000 years.

Rowe et al. (2009) produced lifetime predictions for non-exposed HDPE geomembranes immersed in landfill leachate. As seen within Table 9-2, the total predicted service life at a temperature of $20^{\circ} \mathrm{C}$ is estimated to be between 685 to 1905 years.

Table 9-2. Rowe et al. (2009) Lifetime Prediction for Non-Exposed HDPE Geomembranes Immersed in Landfill Leachate.

\begin{tabular}{|c|c|c|}
\hline $\begin{array}{c}\text { Temperature } \\
\left({ }^{\mathbf{}} \mathbf{C}\right)\end{array}$ & $\begin{array}{c}\text { Minimum Total Predicted } \\
\text { Service Life } \\
\text { (years) }\end{array}$ & $\begin{array}{c}\text { Maximum Total Predicted } \\
\text { Service Life } \\
\text { (years) }\end{array}$ \\
\hline 20 & 685 & 1905 \\
\hline 35 & 150 & 380 \\
\hline 50 & 40 & 90 \\
\hline
\end{tabular}

Peggs (2003) conducted a review of HDPE geomembrane durability literature and concluded that once a HDPE geomembrane is installed with proper QA, its resistance to leakage is a function of its stress crack resistance, its oxidation resistance, its imposed stresses, and its stress relaxation rate. Therefore to increase service life a HDPE geomembrane should be selected with a high stress crack resistance and good thermal ageing properties and should be installed with good QA oversight and testing. Under these conditions Peggs (2003) would expect that a municipal solid waste landfill HDPE geomembrane should last for about 400 years.

Needham et al. (2004) and Needham et al. (2006) conducted a review of HDPE geomembrane durability literature and concluded that HDPE geomembrane service life is dependent upon its material degradation and the subsequent formation of holes by tensile stress cracking. Based upon this review Needham et al. (2004) and Needham et al. (2006) developed a methodology for combining HDPE degradation mechanisms (antioxidant depletion, thermal oxidation, and tensile stress cracking) into an estimate of generation of holes over time. Also based upon their review, they developed the Table 9-3 estimates of the antioxidant depletion period.

Table 9-3. Needham et al. (2004) and Needham et al. (2006) Antioxidant Depletion Period Prediction.

\begin{tabular}{|c|c|}
\hline $\begin{array}{c}\text { Temperature } \\
\left({ }^{\mathbf{0}} \mathbf{C}\right)\end{array}$ & $\begin{array}{c}\text { Antioxidant Depletion Period } \\
\text { (years) }\end{array}$ \\
\hline 20 & 450 to 1,300 \\
\hline 30 & 140 to 530 \\
\hline
\end{tabular}

Benson (2014) indicates that the lifespan of HDPE geomembranes control the service life of covers and that current research indicates that HDPE geomembranes have lifespans on the order of 500 to 1500 years.

The following are some of the best information sources dealing with the continued research associated with HDPE geomembrane longevity: 
- The Geosynthetic Institute (GSI) in Folsom, Pennsylvania (http://www.geosyntheticinstitute.org/) provides specifications (http://www.geosynthetic-institute.org/specs.htm); white papers (http://www.geosynthetic-institute.org/whitepapers.htm); and listings of GSI related published papers (http://www.geosynthetic-institute.org/gripub/gmp.html) associated with geomembranes.

- GSE Lining Technology, LLC (http://www.gseworld.com/) is a manufacturer of HDPE geomembranes. Their web site provides detailed drawings, published articles, and technical notes associated with their products (http://www.gseworld.com/about-us/literature.html).

- The Geo-Engineering Centre at Queen’s University in Kingston, Ontario, Canada (http://www.geoeng.ca/) has a Barrier Systems Project, which has resulted in a significant amount of research and papers regarding the service life of HDPE geomembranes (http://www.geoeng.ca/BarrierSystemsPapers.html).

\subsection{GCL Divalent Cation Exchange}

The bentonite used in GCLs is generally sodium- or calcium-bentonite. Sodium-bentonite is used more frequently than calcium-bentonite because of its superior swelling capacity and lower initial saturated hydraulic conductivity (Witt and Siegmund 2001). Degradation by divalent cation exchange is also applicable to CCLs if the clay content of the soil utilized consists of sodium bentonite or if sodium bentonite is blended into the soil to produce the CCL. Manufacturers' typically list the maximum initial saturated hydraulic conductivity of sodium-bentonite GCLs as 5.0E-09 cm/s (GSE 2013; CETCO 2013). However sodium-bentonite GCLs are susceptible to exchange of sodium with divalent cations such as calcium and magnesium particularly when calcium and magnesium rich soils overly the GCL (Benson 1999; Bonaparte et al. 2002; Egloffstein 2001). Disposal of concrete debris from the D\&D of facilities and the use of limestone or dolomite as a cover or liner material of construction can also be sources of divalent calcium and magnesium. The conversion of hydrated sodium-bentonite to calcium- and/or magnesium-bentonite results in a decrease in the swell potential or potential volume of water bound to the mineral surface (i.e., immobile water) and a subsequent increase in the saturated hydraulic conductivity of the GCL particularly under conditions of low confining or overburden stress such as found in typical covers (i.e. 2 to 5 feet of overburden) (Bonaparte et al. 2002; Egloffstein 2001; Jo et al. 2005). Increased overburden stress such as found in typical liners can partially compensate for such conversions.

One of the most comprehensive studies regarding the impact of divalent cation solutions on sodiumbentonite GCLs has been conducted by Jo et al. (2005). Jo et al. (2005) permeated sodium-bentonite GCL samples with deionized water, $100 \mathrm{mM} / \mathrm{L}$ sodium chloride $(\mathrm{NaCl})$ and potassium chloride $(\mathrm{KCl})$ solutions, and calcium chloride $\left(\mathrm{CaCl}_{2}\right)$ solutions ranging from 5 to $500 \mathrm{mM} / \mathrm{L}$ until further changes in saturated hydraulic conductivity were not detected (in some cases this took more than 2.5 years and up to 686 pore volumes). Two different effective stresses on the samples were utilized (i.e. 338 and 491 psf). $\mathrm{CaCl}_{2}$ solutions should be representative of the behavior of sodium-bentonite GCLs to solutions containing divalent cations in general. Table 9-4 presents a summary of the results from Jo et al. (2005). The following are the primary conclusions drawn by Jo et al. (2005):

- Permeation of the sodium-bentonite GCL with weak divalent solutions (i.e., $\mathrm{CaCl}_{2} \leq 20 \mathrm{mM} / \mathrm{L}$ $\left.\left(\sim 850 \mathrm{mg} / \mathrm{L} \mathrm{Ca}^{+2}\right)\right)$, resulted in an initially low saturated hydraulic conductivity, which did not change for some time. Subsequently, the saturated hydraulic conductivity gradually increased. Such samples subjected to an effective stress of $338 \mathrm{psf}$ ( $\sim 3$ feet of soil overburden) experienced approximately an order of magnitude saturated hydraulic conductivity increase. Such samples subjected to an effective stress of 491 psf ( $\sim 4.5$ feet of soil overburden) experienced about a fivefold increase. Measurements of the exchange complex after testing showed that exchange of $\mathrm{Ca}^{+2}$ 
for $\mathrm{Na}^{+}$was essentially complete regardless of which weak divalent solution was used. That is the sodium-bentonite was completely converted to calcium-bentonite.

- Permeation of the sodium-bentonite GCL with strong divalent solutions $\left(\mathrm{CaCl}_{2} \geq 50 \mathrm{mM} / \mathrm{L}\right.$ $\left.\left(\sim 2,000 \mathrm{mg} / \mathrm{L} \mathrm{Ca}^{+2}\right)\right)$ resulted in an almost immediate ( $<1$ day) increase in saturated hydraulic conductivity of approximately three orders of magnitude $(\sim 1.0 \mathrm{E}-06 \mathrm{~cm} / \mathrm{s})$. The high $\mathrm{Ca}^{+2}$ concentrations resulted in rapid $\mathrm{Na}^{+}$exchange, conversion to calcium-bentonite and a saturated hydraulic conductivity increase.

In summary, GCLs containing sodium bentonite are vulnerable to saturated hydraulic conductivity increases due to cation exchange of the sodium with divalent cations such as calcium and magnesium. Infiltrating water containing $100 \mathrm{~s}$ of $\mathrm{mg} / \mathrm{L} \mathrm{Ca}^{+2}$ can result in a five to ten-fold increase in saturated hydraulic conductivity over time (i.e. $2.5 \mathrm{E}-08$ to $5 \mathrm{E}-08 \mathrm{~cm} / \mathrm{s}$ from manufacturers' initial maximum). Infiltrating water containing $1,000 \mathrm{~s}$ of $\mathrm{mg} / \mathrm{L} \mathrm{Ca}^{+2}$ can result in an immediate thousand-fold increase in saturated hydraulic conductivity (i.e. $5 \mathrm{E}-06 \mathrm{~cm} / \mathrm{s}$ from manufacturers' initial maximum). Even if an overlying HDPE geomembrane is utilized, the underlying GCL can be contacted with infiltrating water through the holes in the geomembrane. Therefore GCL degradation by divalent cations should be addressed as a degradation mechanism within PAs.

Table 9-4. GCL Average Saturated Hydraulic Conductivity (Jo et al. 2005).

\begin{tabular}{|c|c|c|c|c|c|}
\hline \multirow[b]{2}{*}{ Parameter } & \multicolumn{5}{|c|}{ Permeant } \\
\hline & $\begin{array}{l}\text { Deionized } \\
\text { Water }\end{array}$ & $\begin{array}{c}100 \mathrm{mM} / \mathrm{L} \\
\mathrm{NaCl} \text { or } \mathrm{KCl}\end{array}$ & $\begin{array}{c}5 \text { to } 20 \\
\mathrm{mM}^{\prime} \mathrm{L}^{1} \\
\mathrm{CaCl}_{2} \text { at } 338 \\
\text { psf Effective } \\
\text { Stress }\end{array}$ & $\begin{array}{c}5 \text { to } 20 \\
\mathrm{mM}^{1} \mathrm{~L}^{1} \\
\mathrm{CaCl}_{2} \text { at } 491 \\
\text { psf Effective } \\
\text { Stress }\end{array}$ & $\begin{array}{c}50 \text { to } 500 \\
\mathrm{mM} / \mathrm{L}^{2} \\
\mathrm{CaCl}_{2}\end{array}$ \\
\hline Initial $\mathrm{K}_{\text {sat }}(\mathrm{cm} / \mathrm{s})$ & 2.1E-09 & 3.6E-09 & 2.6E-09 & 2.1E-09 & $1.2 \mathrm{E}-06$ \\
\hline Final $K_{\text {sat }}(\mathrm{cm} / \mathrm{s})$ & 3.0E-09 & 4.8E-09 & 2.4E-08 & $1.1 \mathrm{E}-08$ & 1.3E-06 \\
\hline $\begin{array}{l}\text { Final } \mathrm{K}_{\text {sat }} / \text { Initial } \\
\text { DI Water } \mathrm{K}_{\text {sat }}\end{array}$ & 1.4 & 2.3 & 11.4 & 5.2 & 619 \\
\hline
\end{tabular}

Notes to Table 9-4:

- Source: Jo et al. (2005) Table 2

- $\quad \mathrm{K}_{\mathrm{sat}}=$ saturated hydraulic conductivity

1209 to $848 \mathrm{mg} / \mathrm{L} \mathrm{Ca}^{+2}$

21,985 to $19,400 \mathrm{mg} / \mathrm{L} \mathrm{Ca}^{+2}$

The following are some of the best information sources dealing with the continued research associated with GCLs:

- The GSI in Folsom, Pennsylvania (http://www.geosynthetic-institute.org/) provides specifications (http://www.geosynthetic-institute.org/specs.htm); white papers (http://www.geosyntheticinstitute.org/whitepapers.htm); and listings of GSI related published papers (http://www.geosynthetic-institute.org/gripub/gclp.html) associated with GCLs.

- Significant GCL research has been conducted under the direction of Dr. Craig H. Benson at the University of Wisconsin-Madison in the Geological Engineering program.

- The Geo-Engineering Centre at Queen's University in Kingston, Ontario, Canada (http://www.geoeng.ca/) has a Barrier Systems Project, which has resulted in a significant amount of research and papers regarding GCLs (http://www.geoeng.ca/BarrierSystemsPapers.html).

- GSE Lining Technology, LLC (http://www.gseworld.com/) is a manufacturer of GCLs. Their web site published articles (http://www.gseworld.com/Knowledge-Library/Published-Articles/), 
and technical notes (http://www.gseworld.com/Knowledge-Library/Technical-Notes/) associated with their products.

\subsection{GCL and CCL Desiccation, Root Penetration, and Burrowing Animals}

While the cover can be designed to preclude GCL and CCL desiccation, root penetration, and burrowing animals, they are well known degradation mechanisms that are often of concern to the regulators and stakeholders. Therefore these degradation mechanisms should be addressed in terms of the design features incorporated to prevent such degradation. The following provides information useful in this regard.

It has often been reported that GCLs have the ability to self-heal after desiccation (Boardman and Daniel 1996; Carson 2001; Egloffstein 2001; Witt and Siegmund 2001). However the following must be taken into consideration in relation to the potential desiccation self-healing properties of GCLs:

- After desiccation and subsequent cracking of a GCL, it can take a significant period of time (i.e., potentially days) upon rewetting to seal the cracks and re-achieve the initially low saturated hydraulic conductivity. This delay in crack sealing can allow preferential saturated flow through the cracks rather than through the GCL matrix during the resealing period (Hawkins 1962; Bonaparte et al. 2002; Witt and Siegmund 2001).

- The alteration of sodium-bentonite to calcium- and/or magnesium-bentonite can potentially reduce the swell potential of the bentonite to such an extent that cracks formed during desiccation cannot completely swell shut upon rewetting thus increasing the saturated hydraulic conductivity of the GCL by several orders of magnitude (Benson 1999; Chien et al. 2006; Egloffstein 2001; Lin and Benson 2000; Witt and Siegmund 2001).

The following can preclude or reduce the impact of GCL desiccation and desiccation combined with the alteration of sodium-bentonite to calcium- and/or magnesium-bentonite on the saturated hydraulic conductivity of the GCL and potential infiltration:

- A sufficient thickness of soil overlying the GCL can be provided to significantly limit the potential for desiccation and maintain relatively constant water content. The thicker the overlying soil, the less likely desiccation cracks will form within the GCL. There is little danger of desiccation at all for GCLs overlain by six feet or more of soil and located in humid environments with a relatively uniform annual precipitation. (Hawkins 1962; Egloffstein 2001; Witt and Siegmund 2001).

- The GCL can be overlain by both a geomembrane and a minimum of several feet of soil to prevent desiccation, maintain constant water content, and preclude or reduce the rate of alteration of sodium-bentonite to calcium- and/or magnesium-bentonite (Benson 1999; GSE 2010a; Lin and Benson, 2000). Benson 1999 takes this further by stating that "GCLs should not be used without being overlain by a geomembrane.”

- The soil overlying the GCL should not contain an abnormally high concentration of soluble salts containing divalent cations such as $\mathrm{Ca}^{+2}$ or $\mathrm{Mg}^{+2}$ (GSE 2010a; Jo et al. 2005).

- Calcium bentonite can be used rather than sodium bentonite. While calcium bentonite has a smaller swelling capacity and a somewhat higher initial hydraulic conductivity, it more resistance to degradation due to exchange with external cations and therefore will maintain its self-healing capacity and a more constant saturated hydraulic conductivity (Hawkins 1962; Egloffstein 2001; Witt and Siegmund 2001; Serrato 2007).

The potential for desiccation damage of both exposed and covered CCLs has been recognized for some time (Phifer 1991; Phifer et al. 1993; Phifer et al. 1995; Bonaparte et al. 2002; Albright et al. 2006a; 
Albright et al. 2006b; NRC 2007; Taha and Taha 2011). Desiccation damage does not just refer to damage caused by exposed air drying of CCLs; it also refers to the cyclic changes in moisture content of CCLs that result in non-recoverable stain and potential cracking (Phifer 1991; Phifer et al. 1993; Phifer et al. 1995). The resilience of CCLs to desiccation damage is influenced by the following:

- Soils selected for CCLs with lower clay fraction are more resilient (Benson 2012)

- Fine-grained soils selected for CCLs with greater silt fractions are more resilient (Benson 2012)

- Soils selected for CCLs with a lower shrink/swell capacity are generally more resilient to desiccation damage

- CCLs that are compacted to high densities are less resilient, because nature tend to loosen dense soils (Benson 2012)

- CCLs that are compacted at high moisture contents to eliminate clods are less resilient, because nature tends to add structure (Benson 2012)

While soils can be selected and compacted to produce CCLs that are more resilient to desiccation damage, most CCLs will be subject to some degree of desiccation damage unless sufficient overlying protective layers are provided. Benson 1999 reported on several field studies that demonstrated the favorable field experience of CCLs directly overlain by geomembranes (i.e. composite hydraulic barrier) and relatively thick soil layers in regards to eliminating desiccation.

Composite barriers typically consist of a geomembrane over a GCL or CCL or both. The use of a GCL or CCL as the sole hydraulic barrier results in infiltration through the barrier over its entire surface area when subjected to a positive hydraulic head. Additionally, experience has shown that closure caps that rely solely on GCLs and CCLs as the hydraulic barrier are prone to failure, whereas composite barriers appear to function extremely well. The use of a geomembrane as the sole hydraulic barrier placed over a permeable soil results in flow through any geomembrane holes that "can approach the rate of flow through a similarly-sized orifice”.

Because geomembranes are nearly impervious, the use of a composite barrier results in infiltration/percolation essentially only occurring at the location of geomembrane holes, where such leakage is subsequently impeded by the presence of the GCL, CCL, or both (i.e., flow will be much slower than flow through an orifice). While GCLs, CCLs, or geomembranes can be used as a sole hydraulic barrier, the combination of components in a composite barrier has proven (both theoretically and through field performance) to be most effective in terms of minimizing infiltration/percolation through the barrier (Benson 1999; Bonaparte et al. 2002; Chien et al. 2006).

Benson 1999 reported on several field studies that evaluated the performance of geomembrane/CCL composite hydraulic barriers in closure cap situations and made the following observations:

- At a site in Hamburg, Germany a closure cap profile consisting of from top to bottom a 2-foot vegetative soil layer, a 1-foot sand drainage layer, and a composite hydraulic barrier consisting of a 60-mil HDPE geomembrane overlying a 2-foot CCL was tested. Percolation through this closure cap with a composite hydraulic barrier leveled off between 0.08 and $0.12 \mathrm{in} / \mathrm{yr}$. This percolation was nearly two orders of magnitude less than percolation through a closure cap profile with a CCL as the sole hydraulic barrier at the same location $(\sim 8 \mathrm{in} / \mathrm{yr})$. "Test pits excavated in the composite cover test sections showed that the geomembrane prevented desiccation cracking of the clay. The compacted clay beneath the geomembrane was moist, pliable, and homogeneous even after the cover had been exposed to drought.”

- At the Kettleman Hills hazardous waste landfill in southern California (semi-arid climate) a closure cap profile consisting of from top to bottom a 2-foot vegetative soil layer and a composite 
hydraulic barrier consisting of a 60-mil HDPE geomembrane overlying a 3-foot CCL constructed with highly plastic clay was evaluated. "After six months of exposure to ambient conditions, test pits were excavated to examine the condition of the clay in each test pad. The compacted clay barrier in the composite cover was devoid of cracks. The clay was moist, soft, and pliable as if it had just been placed.”

- At a site in Steamboat Springs, Colorado test pits were dug three years after construction into a closure cap profile with a composite hydraulic barrier. The compacted clay in the composite cover was still moist and un-cracked.

Plant roots can freely penetrate unprotected GCLs and CCLs resulting in increases in the hydraulic conductivity of the GCL (Bonaparte et al. 2002; Carson 2001; Witt and Siegmund 2001). However a GCL and/or a CCL overlain by an intact HDPE geomembrane are protected from root penetration. Intact HDPE geomembranes are impervious to roots and cause roots to follow laterally atop the geomembrane surface (Landreth 1991; Badu-Tweneboah et al. 1999; Carson 2001; Serrato 2004; Newman et al. 2004).

Burrowing animals can potentially damage unprotected GCLs and CCLs; however they can be protected from burrowing animal damage by an overlying biointrusion layer designed to preclude burrowing animals from burrowing deeper. Such biointrusion layers consist of a relatively thick layer of cobbles or rip rap.

In order to preclude damage to GCLs and CCLs by desiccation, root penetration, and burrowing animals the following cover design features are suggested:

- A biointrusion layer consisting of a relatively thick (1 to 3 feet) layer of cobbles or rip rap should overlie the hydraulic barrier layers (i.e. HDPE geomembrane, GCL, and/or CCL) in order to preclude damage by burrowing animals. While such a biointrusion layer may reduce the impact of root penetration, it can not necessarily preclude it.

- A composite barrier (i.e. geomembrane over a GCL or CCL or both) should be utilized to minimize infiltration and to protect the GCL and/or CCL from desiccation and root penetration damage. Even at the end of the service life of HDPE geomembranes, defined in terms of a reduction in geomembrane material properties rather than in terms of disintegration or disappearance, the bulk of the HDPE geomembrane will remain intact and will continue to limit potential desiccation and root penetration damage far into the future. It has been estimated that a 60-mil thick HDPE geomembrane would take 10,000,000 years for complete oxidation (Albertsson and Banhidi 1980; Needham et al. 2004).

- The thickness of soil materials that overlie the composite barrier should be sufficient so that the composite barrier is below the zone of ET (i.e. typically six feet or more of in humid environments).

\subsection{Leachate and Chemical Compatibility with HDPE Geomembranes and GCLs}

\section{HDPE Geomembrane}

A significant number of studies have been conducted in the laboratory on leachate effects on HDPE geomembranes and in general no significant deterioration in physical or mechanical properties has been recorded in any of them (Needham et al. 2004). Based upon these tests, HDPE manufacturers' have compiled chemical resistance charts which are generally reliable (Koerner 1998). Additionally these tests have generally shown that municipal solid waste landfill leachate is relatively benign towards HDPE geomembranes, therefore chemical resistance tests are now rarely required in the United States (Needham et al. 2004). However the following chemical degradation mechanisms have been reported: 
- As outlined in Section 9.4 above, the fluid within which HDPE is exposed does impact the rate of its degradation (leachate>water $>$ air).

- HDPE geomembrane contact with some organic compounds, either as a concentrated solution or as pure liquids, can cause absorption of the organic into HDPE which causing subsequent swelling and softening of the geomembrane. In general this condition is reversed and the geomembrane returns to its original condition once the organic is no longer present at the geomembrane surface (Needham et al. 2004).

- HDPE geomembranes can be incompatible with some organic solutions at high concentrations (i.e., pure products) (INEEL 2005).

- The oxidation rate of HDPE geomembranes in contact with solutions containing transition metals such as copper, manganese, and iron may be significantly increased at the surface of the geomembrane, because the dissolved metals may break down hydroperoxides in the geomembrane and create additional free radicals. (Rowe and Sangam 2002; Needham et al. 2004).

- HDPE geomembranes are generally not compatible with strong oxidizers such as ozone (GSE 2004).

The following are the conclusions of several chemical resistance tests that have been performed on HDPE geomembranes in low-level radioactive waste disposal service:

- Whyatt and Fansworth (1990) evaluated a 60-mil HDPE geomembrane in simulated short-term (up to 120 days) chemical compatible tests with a high $\mathrm{pH}(\sim 14)$ inorganic solution at $90^{\circ} \mathrm{C}$ and subjected them to radiation doses ranging from 0.6 to $38.9 \mathrm{Mrad}$. The solution consisted predominately of the following in descending order: sodium, nitrite, nitrate, aluminum, potassium, and sulfate. It was concluded that the HDPE geomembrane was chemically compatible with the inorganic solution. With immersion in the solution but no radiation dose, no significant sample dimensional changes occurred, and the yield, break, and puncture strengths and their associated elongations all increased (i.e. properties improved) over time. However with immersion in the solution and an applied radiation dose, the break strength and elongation decreased (i.e. properties degraded), while yield and puncture strengths and their associated elongations all increased (i.e. properties improved). The 38.9 Mrad dose was slightly greater than the break elongation halfdose value (see Appendix B for the definition of the half-dose value) of the HDPE geomembrane under the conditions tested. No other properties tested were near the half-dose value. From this work it was also concluded "that radiation does not make the liner more susceptible to chemical degradation."

- Compatibility testing was performed on the 60-mil smooth HDPE geomembrane planned for the Hanford Grout facility. HDPE samples were exposed to a dose rate of 740,000 rads per hour until a total radiation dose of $16 \mathrm{Mrad}$ or $37 \mathrm{Mrad}$ was reached. The total dose of $37 \mathrm{Mrad}$ resulted in a greater than $25 \%$ decrease in geomembrane strength and elasticity. Then the HDPE was immersed in a $194^{\circ} \mathrm{F}$ solution with a $\mathrm{pH}$ of 9.2 and a concentration of inorganics of 368,336 mg/L. It was stated that under these conditions the HDPE showed no unacceptable effects (INEEL 2004).

Manufacturer chemical resistance charts can be found at the following web sites:

- GSE Lining Technology, LLC:

- http://www.gseworld.com/content/documents/technicalnotes/Chemical_Resistance_Chart-TECHNICAL_NOTE.pdf)

- http://www.gseworld.com/content/documents/technicalnotes/Chem_Resist_Geomembrane_Technical_Note.pdf 


\section{GCL}

Sodium bentonite is the primary clay mineral in GCLs, which results in a low saturated hydraulic conductivity and high swell potential. Exposure of sodium bentonite to liquids containing concentrated salts (such as brines) or high concentrations of divalent cations (such as $\mathrm{Ca}++$ and $\mathrm{Mg}++$ ), reduces the swelling potential and increases its saturated hydraulic conductivity. Concentrated organic solutions with a low dielectric constant (such as pure gasoline, heptane, and trichloroethylene) and very acidic or basic solutions can break down the soil, which can also increases saturated hydraulic conductivity. The physical mechanism that causes these changes is a reduction of the thickness or absorption capacity of the diffuse double layer of water molecules surrounding the clay minerals. This results in an effective decrease in the volume of the clay because the water molecules are not attracted to the clay particles (INEEL 2005). 


\subsection{Design and Assessment}

As discussed at the beginning of this report, engagement with the stakeholders is critical throughout the process in order to explain the basis for the approach that is adopted and to help focus efforts on aspects that are of the greatest concern. It is important to seek to understand the specific concerns and build the process around addressing those concerns in addition to demonstrating compliance. The areas of focus for the assessment will be based on a combination of the specific considerations identified in the analysis and the areas of interest for the stakeholders.

This report is presented in increasing levels of detail that support implementation of a graded and iterative approach to the PA. The first level of information is intended to help present and describe the barriers that are included in the disposal system and how they function together to provide a robust facility. This is followed by more specific information to help describe the roles and functions of different components of the barriers. This information is placed in context with performance by including information about processes and events that can compromise or potentially improve the performance of different components in the disposal system. This information is used to develop a conceptualization of the system for an initial assessment of performance. For cases where the assessment needs to be refined and focused on the factors that are significant for performance, detailed information is provided to support determining the estimated timing and extent of changes to the key barriers. The level of detail required depends on the site (e.g., wet versus dry) and the waste being disposed.

In the case of cover and liner systems, there is significant uncertainty about the timing of changes in performance. The relative timing of changes in cover and liner performance is a critical factor in terms of how water is managed by the disposal system. This relationship will be a focus of attention when addressing long-term performance of the facility. As part of the graded approach, decisions will need to be made about what features to take credit for (and defend) and features that can be identified as defensein-depth. In some cases, it may be more effective to address uncertainties through design or waste acceptance criteria. This section provides an approach to manage those uncertainties through a combination of design and assessment. Waste acceptance criteria can also be established to limit the source term that would be disposed for cases where the uncertainties cannot be sufficiently resolved.

\subsection{Design Considerations}

The following provides design approaches to address factors that influence performance of various cover and liner layers based upon the layer's function and degradation mechanisms. Using these design principles is intended to help reduce the uncertainty regarding long-term performance of individual components.

The impact on the cover of underlying waste layer subsidence, if it is not too aerially extensive, may be somewhat mitigated by the use of geo-reinforcement in association with the foundation layer and/or CCL. However degradation of the geo-reinforcement would need to be considered in association with the anticipated length of time it would mitigate underlying waste layer subsidence.

The ET layer (vegetative cover; topsoil; soil water storage layer; and capillary barrier) functions to remove water from the cover system through ET and runoff in order to minimize infiltration, while at the same time controlling erosion. ET, rather than runoff, is typically the dominant means of water removal; therefore designs tend to promote ET more than runoff. In fact, from a design perspective, the promotion of runoff must be carefully balanced versus the minimization of erosion. The following are design considerations associated with the ET layer for both ET and conventional covers: 
- Surface slopes are typically 2 to $5 \%$.

- The soil water storage layer should consist of fine grained soil such as silts and clayey silts (loamy soils) that promote water storage. Consideration should be given to making this layer at least as thick as the site-specific ET zone depth (i.e. average depth of root penetration and thickness of soil subject to significant moisture content variations).

- While the use of cobbles or coarser grained materials within the topsoil and soil water storage layer is sometimes considered as a means to reduce erosion, it also reduces the water storage capacity of these layers and can negatively influence ET. Therefore such usage is discouraged in humid regions; it is not as much a concern in arid regions where such additives can help to address potential wind erosion. In humid regions it is typically preferable to reduce the surface slope to minimize erosion rather than to use cobbles within the topsoil and soil water storage layer.

- The use of a coarse grained layer below the soil water storage layer should be considered to provide a capillary break for the promotion of ET. This provides added defense-in-depth to control infiltration beneath the storage layer.

The biointrusion layer (granular filter; geotextile filter fabric; and/or rip rap or cobbles) primarily functions to prevent burrowing animals and preclude further erosion. When a composite barrier is utilized within a cover, the inclusion of an overlying biointrusion layer is highly suggested to prevent burrowing animal damage to barrier layers. The following are design considerations associated with the biointrusion layer:

- The rip rap or cobble materials selected for use should be durable as determined through rock durability testing (e.g. ASTM 2003a; ASTM 2003b; ASTM 2004; ASTM 2005; Johnson 2002).

- A layer of rip rap or cobbles would typically have large voids into which overlying soil material could migrate reducing the thickness of the overlying layers. Consideration should be given to either filling the voids of the rip rap or cobble layers or preventing the migration of overlying soil material into the voids. The use of an overlying granular filter and geotextile filter fabric could be used to minimize migration of overlying soils into the voids.

The lateral drainage layer (granular filter; geotextile filter fabric; geonet composite and/or gravel/sand; and/or geotextile protective fabric), in conjunction with the underlying composite barrier, functions to divert infiltrating water away from the underlying waste and transport the water to the perimeter drainage system thus minimizing infiltration into the waste. The following are design considerations associated with the lateral drainage layer:

- If gravel/sand is utilized it should consist of a durable and relatively geochemically neutral material such as quartz or granite. Materials such as limestone and dolomite or other materials that produce divalent cations should be avoided, because of the potential divalent cation impact on an underlying GCL or CCL, if present.

- Where slopes allow, the use of gravel/sand rather than a geonet composite is preferred because of the uncertainty associated with the longevity of the geotextile filter fabric portion of the geonet composite.

- If a geonet composite is used as the sole component of the lateral drainage layer, consideration should be given to overlying the geonet composite with a sand layer so that when the geotextile filter fabric portion of the geonet composite fails, the geonet will be infilled with the permeable sand and the drainage functionality will be maintained.

The cover composite barrier (HDPE geomembrane and a GCL and/or a CCL), in conjunction with the overlying lateral drainage layer, functions to divert infiltrating water away from the underlying waste and 
transport the water to the perimeter drainage system thus minimizing infiltration into the waste. The following are design considerations associated with the composite barrier layer:

- If a hydraulic barrier layer is required in the cover, it should consist of a composite barrier defined as a geomembrane overlying a GCL and/or CCL. A geomembrane should not be used without an underlying GCL and/or CCL because any geomembrane holes would provide a direct path for infiltration to the waste. A GCL and/or CCL should not be used without an overlying geomembrane to protect it from desiccation, root penetration, and divalent cations.

- In addition to being overlain by a geomembrane, GCLs and CCLs should also be overlain by a sufficient thickness of soil to help prevent desiccation and maintain constant water content. In a humid environment with a relatively uniform annual precipitation, six feet or more of soil is deemed sufficient.

In addition to designing the side slopes and toes of covers for seismic stability, the NRC has also required that covers under their purview be designed for physical stability relative to erosion during a site-specific PMP event. A PMP is defined as the theoretically greatest depth of precipitation for a given duration that is physically possible over a given storm size area at a particular geographic location. Physical stability relative to erosion is defined as the prevention of riprap movement during a site-specific PMP. The NRC requires that the riprap for the side slopes and toes be sized per the Abt and Johnson Method (Abt and Johnson 1991 and Johnson 2002 Appendix D Section 2 for side slopes and Section 6 for toes). Additionally the NRC requires that the rip rap selected for use be durable as determined through rock durability testing (e.g. ASTM 2003a; ASTM 2003b; ASTM 2004; ASTM 2005; Johnson 2002).

During the operation and institutional control periods, the leachate collection system (granular filter; geotextile filter fabric; geonet and/or gravel/sand; perforated collection pipes; and/or geotextile protective fabric), in conjunction with the underlying primary liner, functions to limit migration to the leak detection system and to encourage lateral drainage to a sump in order to remove leachate from the landfill. The design considerations associated with the lateral drainage layer as outlined above also apply to the leachate collection system. In addition, geochemical compatibility of the gravel/sand with the anticipated leachate characteristics should be ensured.

The primary liner (HDPE geomembrane and GCL) functions to direct moisture to the leachate collection system and to limit downward migration to the secondary liner. The primary liner should at a minimum be a composite barrier consisting of a HDPE geomembrane overlying a GCL. A geomembrane should not be used as the primary liner without an underlying GCL because any geomembrane holes would provide a direct path for leakage to the leak detection system. In addition chemical compatibility of the composite barrier with the anticipated leachate characteristics should be ensured.

During the operation and institutional control periods, the leak detection system (granular filter; a geotextile filter fabric; geonet and/or gravel/sand; leak detection piping; and/or geotextile protective fabric), in conjunction with the underlying secondary liner, functions to detect the migration of leachate from the leachate collection system through the primary liner to the leak detection system. The design considerations associated with the leachate collection system also apply to the leak detection system.

The secondary liner (HDPE geomembrane and a GCL and/or a CCL) functions to limit leachate migration out of the landfill to the environment. The design considerations associated with the primary liner also apply to the secondary liner. 


\subsection{Assessment Approach}

The suggested assessment approach reflects the graded and iterative philosophy, which generally involves investing effort to take credit for features that are necessary to make a sound decision. The level of effort involved is closely linked to the source term being disposed and the conditions at the disposal site. For example, it is generally necessary to address cover and liner performance in greater detail at wetter sites, where there is more water that must be managed. At drier sites, more simplified approaches can be sufficient.

The earlier sections have highlighted the need to develop a description of the disposal system and understanding the roles of the different components in the system and events and processes that can change the performance. Appropriate designs can be used to help mitigate many of the potential concerns.

Table 10-1 provides a listing of LLW disposal facilities that have PAs or PA-equivalents which have undergone LFRG review. The table provides an overview of the covers, liners, precipitation, and infiltration through the cover for each facility. As seen there is a clear demarcation between disposal facilities located in humid versus arid regions of the country. The following discussion provides suggestions for approaches to specifically address long term performance of different components in cover and liner systems in the context of a graded approach.

The average precipitation at the humid sites ranges from 49 to 54.4 inches/year and annual precipitation exceeds annual potential evapotranspiration. While the water balance of conventional covers utilized at humid sites is often dominated by ET, sufficient lateral drainage is also required to reduce infiltration to acceptable levels. For SRS LLW disposal facilities under intact cover conditions with an average precipitation of 49 inches/year, the water balance is divided into 66\% ET, 33\% lateral drainage, 1\% runoff, and much less than 1\% infiltration into the waste zone (Phifer et al. 2007). For the Oak Ridge Environmental Management Waste Management Facility (EMWMF) with an average precipitation of 54.4 inches/year, the water balance is divided into $~ 58 \%$ evapotranspiration, $\sim 40 \%$ lateral drainage, $1 \%$ runoff, and much less than 1\% infiltration into the waste zone (Jacobs 1998).

As the cover degrades, the level of ET will typically remain essentially the same, unless significant erosion or subsidence is a concern, but the lateral drainage will decrease over time resulting in increased infiltration. Erosion can reduce the amount of ET by reducing the thickness of the soil water storage layers, and significant subsidence can reduce the amount of ET by promoting water flow (runoff and lateral drainage) into the subsided areas. The amount of lateral drainage decreases over time as the lateral drainage layer plugs and the hydraulic barrier layers degrade resulting in increased infiltration. Conventional covers at humid sites should address the potential for subsidence, erosion, lateral drainage layer pluggage, and hydraulic barrier degradation relative to infiltration over time.

The average precipitation at the arid sites in Table 10-1 ranges from 5 to 13 inches/year and the potential ET greatly exceeds precipitation. Because of this, covers in arid locations rely predominately on ET as the means to limit infiltration and are designed as ET covers. That is they are designed to have a sufficient thickness of fine grained soil (silts and clayey silts) to provide soil water storage to accommodate periods of excessive precipitation for later evapotranspiration. Often a coarse grained layer is located beneath the fine grained soil to provide a capillary break to help maintain moisture in the overlying fine grained soil for ET. In general the inclusion of underlying lateral drainage layers and hydraulic barriers is considered a defense in depth for these ET covers. The infiltration estimates through the Table 10-1 ET covers is primarily based upon the rate of infiltration determined for undisturbed background soils for which the ET cover fine grained soil is designed to mimic. While infiltration modeling may have been conducted for these ET covers, the modeling focused primarily on ET. 
Defense of the assumed infiltration rates associated with ET covers in arid regions is often easier than for conventional covers in humid regions due to the documented low background infiltration rates resulting from the low precipitation rates and high evapotranspiration rates. For the most part, the primary degradation mechanisms that must be addressed for ET covers in arid regions are wind and water erosion that can reduce the thickness of the water storage soil layer and burrowing animals whose burrows might result in increased infiltration through this layer. The potential for significant subsidence can also be a significant concern in relation to infiltration if it is applicable to the ET cover. Degradation of drainage and hydraulic barrier layers is generally of little concern, because they are generally considered a defensein-depth and are credited with little or no reduction in infiltration.

Conventional covers at humid sites can be more of a challenge due to the need to take credit for longerterm performance of a cover to reduce the infiltration rate. In such cases, it is important to consider the roles of the different layers and the uncertainty associated with the evolution of the ability of each layer to continue to function as needed. In essence infiltration will generally increase over time as the combined lateral drainage layer and composite barrier lose their functionality resulting in less lateral drainage and more infiltration. The longevity of the lateral drainage layer and composite barrier and their degradation over time are the primary items associated with conventional covers at humid sites that must be adequately defended and justified. There is a process of identifying the layers critical to meeting performance goals, and then, quantifying ranges of potential lifetimes and the rate at which water can move through the layers.

\section{Lessons Learned from Reviews}

As would be expected, LFRG reviews have generally focused on the basis for the assumed infiltration rates and the timing of changes in those infiltration rates in the context of potential impacts on compliance. As liners are also being included in some disposal cells, assumptions regarding the changes in permeability of the liner over time have also become an area of reviewer interest. Experience has shown that reviewers will expect that the PA will include sufficient information to demonstrate an understanding of the features of a cover and liners that have a significant influence on performance. Likewise, the ability to demonstrate features that are not important (e.g., sensitivity analysis) provides a strong rationale to address any reviewer concerns regarding the performance of a specific feature.

Reviewers tend to place an emphasis on assumptions regarding long-term cover performance that appear to be optimistic relative to background conditions. Any such assumptions attract attention and require additional information. Supplemental field data and demonstration covers have been helpful to provide a basis for reduced infiltration rates that would extend for long periods of time. For example, relatively simple ET cover designs tend to be more robust in terms of defending assumptions regarding long term performance, because they do not rely on performance of as many different features. Covers that depend on drainage layers over clay or synthetic materials to maintain infiltration at a small fraction of background will attract more scrutiny in terms of long term performance, especially for times beyond a few hundred years.

Potential subsidence is an important consideration for long term cover performance. In situations where subsidence is likely, there will be an expectation to consider potential impacts on cover performance as localized subsidence occurs (e.g., cases with containerized waste that may fail over time). Similar to above, covers depending on barriers and drainage layers will tend to receive more scrutiny than ET covers which are less susceptible to significant failures as subsidence occurs. In any case, the impacts of subsidence will be expected to be specifically addressed in all cases. 
It has proven effective with reviewers to be able to demonstrate the effectiveness of compaction protocols and procedures during operations as a means to address potential concerns associated with subsidence. A strong QA program for compaction will help with the justification of a lack of significant subsidence. The use of demonstration covers, lysimeters, or other surrogates has proven helpful to defend expected infiltration rates through covers. Such approaches can also help to identify design improvements and, in general, can build confidence in the assumptions in the PA. There is still a burden to address the applicability of any demonstration to what would be expected for an actual cover.

More recently, bathtubbing has been identified as a potential concern for facilities that use liners and leachate collections systems. Reviewers expect some consideration of what happens after leachate collection is discontinued and the cover begins to fail. In these cases, assuming that all engineered features fail at 100 years is not accepted by default to be a conservative assumption. 
Table 10-1. DOE Low-Level Waste Disposal Facilities - Cover and Liner Overview.

\begin{tabular}{|c|c|c|c|c|c|c|c|}
\hline Facility & $\begin{array}{l}\text { Type of } \\
\text { Facility }\end{array}$ & $\begin{array}{l}\text { Average Annual } \\
\text { Precipitation } \\
\text { (in/yr) }\end{array}$ & Type of Cover & $\begin{array}{c}\text { Basis of Infiltration Estimate } \\
\text { thru Cover }\end{array}$ & $\begin{array}{c}\text { Infiltration } \\
\text { Estimate thru } \\
\text { Cover }\end{array}$ & $\begin{array}{l}\text { Liner } \\
\text { Use }\end{array}$ & $\begin{array}{c}\text { PA } \\
\text { Reference }\end{array}$ \\
\hline $\begin{array}{l}\text { SRS } \\
\text { ELLWF }\end{array}$ & $\begin{array}{l}\text { Trenches } \\
\text { and } \\
\text { Vaults }\end{array}$ & 49 & Conventional & HELP Modeling & $0.06-13.3 \mathrm{in} / \mathrm{yr}^{1}$ & No & $\begin{array}{l}\text { WSRC } \\
2008\end{array}$ \\
\hline $\begin{array}{l}\text { SRS FTF } \\
\text { and } \\
\text { HTF }\end{array}$ & $\begin{array}{l}\text { Grouted } \\
\text { Tanks }\end{array}$ & 49 & Conventional & HELP Modeling & $0.0009-11.5 \mathrm{in} / \mathrm{yr}^{2}$ & No & $\begin{array}{l}\text { SRR } 2010 \\
\text { SRR } 2012\end{array}$ \\
\hline SRS SDF & $\begin{array}{l}\text { Saltstone } \\
\text { filled } \\
\text { Concrete } \\
\text { Tanks }\end{array}$ & 49 & Conventional & HELP Modeling & $0.0004-10.6 \mathrm{in} / \mathrm{yr}^{3}$ & No & SRR 2009 \\
\hline $\begin{array}{l}\text { OR } \\
\text { EMWMF }\end{array}$ & Landfill & 54.4 & Conventional & HELP Modeling & $0.00009-0.4 \mathrm{in} / \mathrm{yr}^{4}$ & $\begin{array}{l}\text { Double } \\
\text { liner }\end{array}$ & Jacobs 1998 \\
\hline $\begin{array}{l}\text { INL } \\
\text { RWMC }\end{array}$ & $\begin{array}{l}\text { Pits and } \\
\text { Vaults }\end{array}$ & 8.4 & $\begin{array}{lrr}\begin{array}{l}\text { ET with } \\
\text { (drainage }\end{array} \text { layer } & \text { and } \\
\text { hydraulic } & \text { barriers } & \text { if } \\
\text { required by regulators) } & \end{array}$ & $\begin{array}{l}\text { Compilation of site-specific } \\
\text { studies, field tests, calculations, } \\
\text { and modeling }\end{array}$ & $\begin{array}{l}0.1 \mathrm{~cm} / \mathrm{yr} \\
(0.04 \mathrm{in} / \mathrm{yr})^{5}\end{array}$ & No & INL 2007 \\
\hline INL ICDF & Landfill & 8.4 & $\begin{array}{l}\text { ET with capillary } \\
\text { break/drainage layer and } \\
\text { hydraulic barriers }\end{array}$ & $\begin{array}{l}\text { Compilation of site-specific } \\
\text { studies, field tests, calculations, } \\
\text { and modeling }\end{array}$ & $\begin{array}{l}0.01-1.0 \mathrm{~cm} / \mathrm{yr} \\
(0.004-0.4 \mathrm{in} / \mathrm{yr})^{6}\end{array}$ & $\begin{array}{l}\text { Double } \\
\text { liner }\end{array}$ & INL 2011 \\
\hline $\begin{array}{l}\text { INL RH- } \\
\text { LLW } \\
\text { Disposal } \\
\text { Facility }\end{array}$ & Vaults & 8.4 & $\begin{array}{l}\text { ET with capillary } \\
\text { break/drainage layer and } \\
\text { hydraulic barrier }\end{array}$ & $\begin{array}{l}\text { Compilation of site-specific } \\
\text { studies, field tests, calculations, } \\
\text { and modeling }\end{array}$ & $\begin{array}{l}0.01-1.0 \mathrm{~cm} / \mathrm{yr} \\
(0.004-0.4 \mathrm{in} / \mathrm{yr})^{7}\end{array}$ & No & INL 2012 \\
\hline $\begin{array}{l}\text { Hanford } \\
\text { IDF }\end{array}$ & Landfill & 6.3 & $\begin{array}{l}\text { ET with modified RCRA } \\
\text { Subtitle C barrier }\end{array}$ & $\begin{array}{l}\text { Compilation of } \\
\begin{array}{l}\text { site-specific } \\
\text { studies, field } \\
\text { calculations }\end{array}\end{array}$ & $\begin{array}{l}0.5 \mathrm{~mm} / \mathrm{yr} \\
(0.02 \mathrm{in} / \mathrm{yr})^{8}\end{array}$ & $\begin{array}{l}\text { Double } \\
\text { liner }\end{array}$ & ORP 2005 \\
\hline $\begin{array}{l}\text { Hanford } \\
\text { ERDF }\end{array}$ & Landfill & 6.89 & $\begin{array}{l}\text { ET with capillary } \\
\text { break/drainage layer and } \\
\text { hydraulic barriers }\end{array}$ & $\begin{array}{l}\text { Compilation of } \\
\begin{array}{l}\text { site-specific } \\
\text { studies, field } \\
\text { calculations }\end{array}\end{array}$ & $\begin{array}{l}0.5-1.0 \mathrm{~mm} / \mathrm{yr} \\
(0.02-0.04 \mathrm{in} / \mathrm{yr})\end{array}$ & $\begin{array}{l}\text { Double } \\
\text { liner }\end{array}$ & WCH 2013 \\
\hline $\begin{array}{l}\text { LANL TA } \\
54, \text { Area G }\end{array}$ & $\begin{array}{l}\text { Pits and } \\
\text { Shafts }\end{array}$ & 13 & $\begin{array}{l}\text { ET with optional capillary } \\
\text { break }\end{array}$ & $\begin{array}{l}\text { Compilation of site-specific } \\
\text { field tests and modeling }\end{array}$ & $\begin{array}{l}0-10 \mathrm{~mm} / \mathrm{yr} \\
(0-0.4 \mathrm{in} / \mathrm{yr}){ }^{10}\end{array}$ & No & LANL 2008 \\
\hline $\begin{array}{l}\text { NTS Area } 5 \\
\text { RWMS }\end{array}$ & Pits & 5 & ET & $\begin{array}{l}\text { Compilation of site-specific } \\
\text { field tests and modeling }\end{array}$ & Negligible $^{11}$ & No & $\begin{array}{l}\text { Shott et. al } \\
1998 ; \\
\text { DOE } 2006\end{array}$ \\
\hline
\end{tabular}


Notes to Table 10-1:

ELLWF = E-Area Low-Level Waste Facility

EMWMF = Environmental Management Waste Management Facility

ERDF = Environmental Restoration Disposal Facility

FTF $=$ F-Area Tank Farm

HTF $=$ H-Area Tank Farm

ICDF $=$ Idaho CERCLA Disposal Facility

IDF = Integrated Disposal Facility

RWMC = Radioactive Waste Management Complex

RWMS = Radioactive Waste Management Site

RH-LLW = Remote-Handled Low-Level Waste

SDF $=$ Saltstone Disposal Facility

$\mathrm{TA}=$ Technical Area

1 Material property values were changed over time to account for degradation of various layers and input to the HELP model (Schroeder 1994a and 1994b) in order to estimate infiltration through the cover over time. In general infiltration estimates after final closure increased from 0.06 in/yr at year zero to $13.3 \mathrm{in} / \mathrm{yr}$ at year 2,800 (not a linear increase). Infiltration estimates after subsidence of the cover occurred were also produced which ranged from 16 to $48 \mathrm{in} / \mathrm{yr}$ depending upon the location and timing of subsidence.

2 Material property values were changed over time to account for erosion, drainage layer pluggage, generation of holes within the HDPE geomembrane, and GCL divalent cation exchange and input to the HELP model (Schroeder 1994a and 1994b) in order to estimate infiltration through the cover over time. Infiltration estimates after final closure increased from $0.0009 \mathrm{in} / \mathrm{yr}$ at year zero to $11.47 \mathrm{in} / \mathrm{yr}$ at year 2,623 (not a linear increase).

3 Material property values were changed over time to account for erosion, drainage layer pluggage, generation of holes within the HDPE geomembrane, and GCL divalent cation exchange and input to the HELP model (Schroeder 1994a and 1994b) in order to estimate infiltration through the cover over time. Infiltration estimates after final closure increased from $0.0004 \mathrm{in} / \mathrm{yr}$ at year zero to $10.6 \mathrm{in} / \mathrm{yr}$ at year 5,412 (not a linear increase).

4 The HELP model (Schroeder 1994a and 1994b) was used to evaluate an intact design case and a worst case. The infiltration estimate after final closure for the design case was $0.00009 \mathrm{in} / \mathrm{yr}$ and it was utilized for the 0 to 100 year time frame. For the worst case the cover geomembrane was assumed to no longer act as a barrier; no other changes were made to any other cover layer. The infiltration estimate for the worst case was $0.4 \mathrm{in} / \mathrm{yr}$ and it was utilized after 100 years.

5 Based upon a compilation of site-specific studies, field tests, calculations, and modeling the cover was assumed to have a baseline average infiltration rate of $0.1 \mathrm{~cm} /$ year through a final cover. The bulk of water removal from the cover is through evapotranspiration. A sensitivity run was conducted at an infiltration rate of $1 \mathrm{~cm} / \mathrm{yr}$ (background infiltration).

6 Based upon a compilation of site-specific studies, field tests, calculations, and modeling, the final cover was assumed to remain intact and perform to design specifications of $0.01 \mathrm{~cm} / \mathrm{yr}$ for 500 years. After 500 years, the cover was assumed to linearly fail, reaching a maximum infiltration rate of $1 \mathrm{~cm} / \mathrm{yr}$ (background infiltration) 1,000 years after installation. The bulk of water removal from the cover is through ET and 
the drainage layer and hydraulic barriers are essentially considered defense in depth. Infiltration was considered in both sensitivity and uncertainty analyses.

7 Consistent with ICDF assumptions an infiltration rate of $0.01 \mathrm{~cm} / \mathrm{yr}$ through the final cover was assumed for 500 years. After 500 years, the cover was assumed to linearly fail, reaching a maximum infiltration rate of $1 \mathrm{~cm} / \mathrm{yr}$ (background infiltration) 1,000 years after installation. The bulk of water removal from the cover is through ET and the drainage layer and hydraulic barrier are essentially considered defense in depth.

8 Based upon a compilation of site-specific studies, field tests, and calculations the final cover was assumed to have an average infiltration rate of $0.5 \mathrm{~mm} / \mathrm{yr}$ throughout time. The bulk of water removal from the cover is through ET and the drainage layer and hydraulic barrier are essentially considered defense in depth.

9 Based upon a compilation of site-specific studies, field tests, and calculations the final cover was assumed to have an average infiltration rate of $0.5 \mathrm{~mm} / \mathrm{yr}$ for 500 years, while the hydraulic barriers were assumed to be intact and of $1.0 \mathrm{~mm} / \mathrm{yr}$ (i.e. long-term background infiltration) after the hydraulic barriers were assumed to have degraded. The bulk of water removal from the cover is through ET and the drainage layer and hydraulic barrier are assumed to remove very little of the water.

10 Based upon a compilation of site-specific field tests and modeling, a range of infiltrations rates through the final cover were considered with the bulk of the values between 0 and $2 \mathrm{~mm} / \mathrm{yr}(0.08 \mathrm{in} / \mathrm{yr})$ and a maximum of $10 \mathrm{~mm} / \mathrm{yr}(0.4 \mathrm{in} . / \mathrm{yr})$. All water removal was assumed to occur through ET.

11 The Nevada Test Site (NTS) Area 5 RWMS PA does not consider a groundwater pathway due to the assumption of negligible infiltration. 
Suggestions for addressing the performance of specific components of cover and liner systems in more detail are provided here.

The following are potential methods for the consideration of subsidence within PAs:

- Demonstrate that significant void volumes have been eliminated by disposal practices and therefore subsidence will not occur.

- Assume that subsidence occurs at the end of the 100-year institutional control period.

- Evaluate degradation and collapse (static or seismic loading as appropriate) of waste forms, containers, and vaults that contain significant void volumes in order to project when subsidence will occur within the 1000-year assessment period.

- Demonstrate that subsidence will not occur within the 1,000-year assessment period due to the integrity of the waste forms, containers, and vaults (static or seismic loading as appropriate) that contain significant void volumes.

- Address subsidence as a sensitivity analysis.

The following are potential methods for the consideration of erosion within PAs:

- Universal Soil Loss Equation (USLE)

(http://www.ars.usda.gov/Research//docs.htm?docid=10626)

- $\quad$ Revised Universal Soil Loss Equation, Version 2 (RUSLE2) (http://fargo.nserl.purdue.edu/rusle2_dataweb/RUSLE2_Index.htm)

- Modified Universal Soil Loss Equation (MUSLE) (http://www.nrcs.usda.gov/Internet/FSE_DOCUMENTS/nrcs143_013359.pdf)

- Various landform models have also been promoted as means of evaluating erosion over 1,000 s of years.

The following are potential methods for the consideration of cover drainage layer pluggage within PAs (appropriate justification should be provided for whichever method is utilized):

- Justify that no significant pluggage of the cover drainage layer will occur and use a constant saturated hydraulic conductivity.

- Demonstrate that cover drainage layer pluggage has very little impact on infiltration.

- Convert the cover drainage layer from a drainage layer to a vertical percolation layer at some agreed upon point in time.

- $\quad$ Reduce the saturated hydraulic conductivity of the cover drainage layer over time based upon the infiltration of water containing an assumed concentration of colloid-sized clays from the overlying soil material and disposition within the drainage layer. This is likely a conservative model for a drainage layer because no credit is taken for flushing of colloids out of the drainage system.

- Address cover drainage layer pluggage as a sensitivity such as by reducing the saturated hydraulic conductivity of the drainage layer by a factor of 10 .

- Address cover drainage layer pluggage and hydraulic barrier degradation together as a sensitivity by assuming that infiltration reverts to background infiltration at some agreed upon point in time.

The following are potential methods for the consideration of leachate collection layer pluggage within PAs (appropriate justification should be provided for whichever method is utilized):

- Justify that no significant pluggage of the leachate collection layer will occur and use a constant saturated hydraulic conductivity. 
- Demonstrate that leachate collection layer pluggage has very little impact on percolation through the liner.

- Convert the leachate collection layer from a drainage layer to a vertical percolation layer at some agreed upon point in time such as at the end of the 100-year institutional control period.

- Address leachate collection layer pluggage as a sensitivity such as by reducing the saturated hydraulic conductivity of the layer by a factor of 10 or 100 .

The following are potential methods for the consideration of HDPE geomembrane degradation within PAs (appropriate justification should be provided for whichever method is utilized):

- Take no credit for the HDPE geomembrane inhibiting infiltration or percolation.

- Assume that the HDPE geomembrane lasts through the end of the 100-year institutional control period.

- Assume that the HDPE geomembrane lasts for an agreed upon time based upon the HDPE geomembrane service life prediction research. Such assumptions may take the form of a step change (i.e. maintain full functionality over the assumed service life) or linear change (i.e. functionality decreases linearly over the assumed service life).

- Utilize the Needham et al. (2004) and Needham et al. (2006) methodology for combining HDPE degradation mechanisms (antioxidant depletion, thermal oxidation, and tensile stress cracking) into an estimate of generation of holes over time.

- Address cover drainage layer pluggage and hydraulic barrier degradation together as a sensitivity by assuming that infiltration reverts to background infiltration at some agreed upon point in time.

The following are potential methods for the consideration of GCL/CCL divalent cation exchange within PAs (appropriate justification should be provided for whichever method is utilized):

- Justify that divalent cation exchange is not a concern because sodium bentonite is not utilized.

- Justify that no significant divalent cations are associated with the material above GCL/CCL and therefore such degradation will not occur and use a constant saturated hydraulic conductivity (if overlying materials include limestone, dolomite, concrete, etc. then this cannot be justified).

- Assume that divalent cation exchange degradation occurs at some agreed upon point in time due to water containing 100s of $\mathrm{mg} / \mathrm{L}$ divalent cations resulting in an order of magnitude increase in saturated hydraulic conductivity from manufactures’ initial maximum. Although an overlying geomembrane can protect the bulk of the GCL/CCL from such degradation, the GCL/CCL will undergo such degradation where holes in the geomembrane exist, which is where flow will occur. Therefore even with the presence of an overlying geomembrane, degradation from divalent cations should be considered. Water containing 1,000s of mg/L divalent cations can result in three orders of magnitude increase in saturated hydraulic conductivity from manufactures' initial maximum.

- Address cover drainage layer pluggage and hydraulic barrier degradation together as a sensitivity by assuming that infiltration reverts to background infiltration at some agreed upon point in time.

GCL/CCL desiccation, burrowing animals, and roots can be addressed within PAs by implementing the following design options that help to preclude these degradation mechanisms (if these design options are not implemented, the impact of these degradation mechanisms on infiltration should be addressed):

- Use a HDPE geomembrane over and have sufficient thickness of material above the GCL/CCL to preclude desiccation and root penetration.

- Use a biointrusion layer (rip rap or cobbles) or have sufficient thickness of material above the HDPE geomembrane/GCL/CCL to preclude burrowing animals. 
The following are potential methods to make infiltration estimates within PAs:

- Utilize background infiltration estimates.

- Conduct field studies to measure infiltration.

- Conduct modeling to estimate infiltration. 


\subsection{References}

\section{PAs or PA-equivalent highlighted in yellow}

Abt, S. R. and Johnson, T. L. 1991. Riprap Design for Overtopping Flow. Journal of Hydraulic Engineering, Volume 117, Number 8, pp. 959-972. August 1991.

Albertsson and Banhidi (1980). Microbial and oxidative effects in degradation of polyethylene. Albertsson, A. C. and Banhidi, Z. G. Journal Applied Polymer Science, John Wiley \& sons, New York, vol. 25, pp. 1655-1671.

Albright, W. H., Benson, C. H., Gee, G. W., Abichou, T., McDonald, E. V., Tyler, S. W., and Rock, S. A. 2006a. Field Performance of Three Compacted Clay Landfill Covers, Vadose Zone Journal, Vol. 5, pp. 1357-1171. November 2006.

Albright, W. H., Benson, C. H., Gee, G. W., Abichou, T., McDonald, E. V., Tyler, S. W., and Rock, S. A. 2006b. Field Performance of a Compacted Clay Landfill Final Cover at a Humid Site, Journal of Geotechnical and Geoenvironmental Engineering, Volume 132, No. 11, pp. 1393-1403. November 2006.

ASTM International. 2003a. Standard Guide for Petrographic examination of Aggregates for Concrete. ASTM C-295-03. ASTM International, West Conshohocken, PA. January 10, 2003.

ASTM International. 2003b. Standard Test Method for Resistance to Degradation of SmallSize Coarse Aggregate by Abrasion and Impact in the Los Angeles Machine. ASTM C-13103. American Society of Testing and Materials, West Conshohocken, PA. March 10, 2003.

ASTM International. 2004. Standard Test Method for Density, Relative Density (Specific Gravity), and Absorption of Coarse Aggregate. ASTM C-127-04. ASTM International, West Conshohocken, PA. August 1, 2004.

ASTM International. 2005. Standard Test Method for Soundness of Aggregates by Use of Sodium Sulfate or Magnesium Sulfate. ASTM C-88-05. ASTM International, West Conshohocken, PA. July 15, 2005.

Badu-Tweneboah, K., Tisinger, L.G., Giroud, J. P., Smith, B. S., 1999. Assessment of the Long-Term Performance of Polyethylene Geomembrane and Containers in a Low-Level Radioactive Waste Disposal Landfill, Geosynthetics '99 Conference Proceedings, Vol. 2, pp. 1055-1070, Industrial Fabrics Association International, Roseville, MN, 55113.

Benson, C. H. 1999. Final Covers for Waste Containment Systems: A North American Perspective. XVII Conference of Geotechnics of Torino: "Control and Management of Subsoil Pollutants”. Torino, Italy. November 23-25, 1999.

Benson et. al 2011, Engineered Covers for Waste Containment: Changes in Engineering Properties and Implications for Long-Term Performance Assessment, NUREG/CR-7028, US Nuclear Regulatory Commission, Office of Nuclear Regulatory Research, December 2011. 
Benson, C. H. 2012. Evolution of Cover Hydraulic Properties: Lessons Learned from ACAP. Presentation at Washington State Department of Ecology Landfill Barrier Technology Workshop. February 1 and 2, 2012.

Benson, C. H. 2014. Performance of Engineered Barriers: Lessons Learned, Performance and Rick Assessment Community of Practice Webinar, February 20, 2014.

Boardman, B.T. and Daniel, D.E. 1996. Hydraulic Conductivity of Desiccated Geosynthetic Clay Liners, Journal of Geotechnical Engineering, Volume 122, No. 3, pp. 204-208.

Bonaparte, R., Daniel, D. E., and Koerner, R. M. 2002. Assessment and Recommendations for Improving the Performance of Waste Containment Systems. EPA/600/R-02/099, United States Environmental Protection Agency, Office of Research and Development, Cincinnati, OH. December 2002.

Carson, D. A. 2001. Geosynthetic Clay Liners in Waste Containment. Presentation found at www.epa.gov/tio/tsp/download/2001_meet/prez/carson.pdf. Office of Research and Development, US Environmental Protection Agency, Cincinnati, OH.

CETCO 2013. (Web site at: http://lining.cetco.com/LeftSideNavigation/GEOSYNTHETICCLAYLINERS/BENTOMAT/tabid/2959/ Default.aspx).

Chien C. C., Inyang, H. I., and Everett, L. G. (editors). 2006. Barrier Systems for Environmental Contaminant Containment and Treatment. CRC Press, Taylor \& Fracncis Group, LLC, Boca Raton, FL.

Crowe, Bruce, K. Leary, R. Jacobson, and H. Bensinger. WM Proceedings, 1999. An Informal Expert Judgment Assessment of Subsidence Mitigation Options for Low-Level Radioactive Waste Management Sites on the Nevada Test Site.

DOE 2006. Addendum 2 to the Performance Assessment for the Area 5 Radioactive Waste Management Site at the Nevada Test Site, Nye County, Nevada - Update of Performance Assessment Methods and Results, DOE/NV/11718--176-ADD2, Nevada Operations Office, Nevada Test Site. June 2006.

Egloffstein, T. A. 2001. Natural bentonites-influence of the ion exchange and partial desiccation on permeability and self-healing capacity of bentonites used in GCLs. Geotextiles and Geomembranes, Volume 19, Issue 7, September 2001, Pages 427-444.

EPA 1989. Final Covers on Hazardous Waste Landfills and Surface Impoundments, Technical Guidance Document, EPA/530/SW-89/047 Office of Solid Waste and Emergency Response, Washington, D. C.

EPA 2011. Fact Sheet on Evapotranspiration Cover Systems for Waste Containment, EPA 542-F-11-001, United States Environmental Protection Agency, Office of Solid Waste and Emergency Response, February 2011.

EDF-ER-279, 2002, “Hydrologic Modeling of Final Cover,” Rev. 2, Environmental Restoration Program, Idaho National Engineering and Environmental Laboratory, May 2002.

FBP 2013. Remedial Investigation and Feasibility Study Report for the Site-Wide Waste Disposition Evaluation Project at the Portsmouth Gaseous Diffusion Plant, Piketon, Ohio, FBP-ER-RIFS-WD-RPT0030, Revision 3, Fluor-B\&W Portsmouth LLC. February 2013. 
GSE (2004). GSE Lining Technology, Inc. (Web site at: http://www.gseworld.com/findproducts.htm).

GSE 2010a. Technical Note: Resistance to Cation Exchange for Fabric Encased GCL Products. GSE Lining Technology, Inc. January 15, 2010. (Web site at:

http://www.gseworld.com/assets/files/pdf/Literature/TN34\%20BLCation.pdf).

GSE 2013. (Web site at: http://www.gseworld.com/Products/Geosynthetic-Clay-Liners/Fabric-Encased/).

GSE 2013. (Web site at: http://www.gseworld.com/Products/Geonets-and-Geocomposites/).

Hawkins, R. H. 1962. Bentonite as a Protective Cover for Buried Radioactive Waste, DPSPU 62-30-3A, E. I. du Pont de Nemours and Company, Aiken, SC. May 1962.

Hsuan and Koerner (1998). Antioxidant depletion lifetime in high density polyethylene geomembranes. Hsuan, Y. G. and Koerner, R. M. Journal of Geotechnical and Geoenvironmental Engineering, ASCE, Vol. 124, No. 6, pp. 532-541.

INEEL 2004. Engineering Design File Project No. 23350 Liner/Leachate Compatibility Study. EDF-ER278, Revision 2, Idaho National Engineering and Environmental Laboratory (INEEL), 6/18/04.

INEEL 2005. Engineering Design File Project No. 23350 Liner/Leachate Compatibility Study, EDF-ER278, Rev. 3, Idaho National Engineering and Environmental Laboratory (INEEL), 01/11/05.

INL 2007. Performance Assessment for the RWMC Active Low-Level Waste Disposal Facility at the Idaho National Laboratory Site, DOE/NE-ID-11243, Idaho National Laboratory. September 2007.

INL 2011. Performance Assessment for the Idaho CERCLA Disposal Facility Landfill, DOE/ID-10978, Rev. 2, Idaho National Laboratory. February 2011

DOE-ID 2011, Performance Assessment for the Idaho CERCLA Disposal Facility Landfill, DOE/ID10978, US Department of Energy Idaho Operations Office, Idaho Falls, ID, February 2011.

INL 2012. Performance Assessment for the Idaho National Laboratory Remote-Handled Low-Level Waste Disposal Facility, DOE/ID-11421, Idaho National Laboratory. April 2012.

Jacobs 1998. Remedial Investigation/Feasibility Study for the Disposal of Oak Ridge Reservation Comprehensive Environmental Response, Compensation, and Liability Act of 1980 Waste, DOE/OR/021637\&D2, Jacobs EM Team, Oak Ridge, TN. January 1998.

Jo, H. Y., Benson, C. H., Shackelford, C. D., Lee, J., and Edil, T. E. 2005. Long-Term Hydraulic Conductivity of a Geosynthetic Clay Liner Permeated with Inorganic Salt Solutions. Journal of Geotechnical and Geoenvironmental Engineering, Vol. 131, No. 4, pp. 405-417, April 2005.

Johnson, T. L. 2002. Design of Erosion Protection for Long-Term Stabilization, NUREG1623. U.S. Nuclear Regulatory Commission, Washington, DC. 139 p.

Jones, W. E. 2010. Closure Cap Drainage Layer Hydraulic Conductivity over Time: Literature Search, SRNL-L6000-2009-00020, Savannah River National Laboratory, Aiken, SC. APRIL 2010.

Koerner, R. M. 1998. Designing with Geosythetics, 4th edition. Koerner, R. M. Prentice Hall, Upper Saddle River, New Jersey. 
Koerner, R. M., Hsuan, Y. G., and Koerner, G. R. 2011. GRI White Paper \#6 on Geomembrane Lifetime Prediction: Unexposed and Exposed Conditions, Geosynthetic Institute, Flosom, PA, February 8, 2011.

Landreth, R. E., 1991. The Resistance of Membranes in Cover Systems to Root Penetration by Grass and Trees, EPA/600/A-92/202, presented at Geosynthetics ’91 Conference, Atlanta, GA.

LANL 2008. Performance Assessment and Composite Analysis for Los Alamos National Laboratory Technical Area 54, Area G, LA-UR-08-06764, Revision 4, Los Alamos National Laboratory. October 2008.

Ligotke, M.W., 1993, Soil Erosion Rates Caused by Wind and Saltating Sand Stresses in a Wind Tunnel, PNL-8478, Pacific Northwest Laboratory, February 1993.

Lin, L. and Benson, C. H. 2000. Effect of Wet-Dry Cycling on Swelling and Hydraulic Conductivity of GCLs. Journal of Geotechnical and Geoenvironmental Engineering, Vol. 126, No. 1, January 2000, pp. 40-49.

Mueller and Jakob (2003). Oxidative resistance of High-Density Polyethylene Geomembranes. Mueller, W. and Jakob, I. Polymer Degradation and Stability, Elsevier Science Ltd. Vol. 79 (2003) pp. 161-172.

NCRP 2005, Performance Assessment of Near-Surface Facility for Disposal of Low-Level Radioactive Waste, NCRP Report No. 152, National Council on Radiation Protection and Measurements, Bethesda, MD, 2005.

Needham, A., Gallagher, E., Peggs, I., Howe, G, and Norris, J. 2004. The likely medium to long-term generation of defects in geomembrane liners. R\&D Technical Report P1-500/1/TR, Environment Agency, Bristol, England.

Needham, A. D., Smith, J. W. N., and Gallagher, E. M. G. 2006. The service life of polyethylene geomembrane barriers. Engineering Geology, Vol. 85, pp. 82-90.

Newman, E. J., Stark, T. D., Rohe, F. P., and Diebel, P., 2004. Thirty-Year Durability of a 20-mil PVC Geomembrane, Journal of Vinyl and Additive Technology, V. 10, Issue 4, pp. 168-173.

Nicholson and Arlt, 2011, Proceedings of the Workshop on Engineered Barrier Performance Related to Low-Level Radioactive Waste, Decommissioning, and Uranium Mill Tailings Facilities, NUREG/CP0195, August 2011.

NRC 2007. Assessment of the Performance of Engineered Waste Containment Barriers. National Research Council, The National Academies Press, Washington, D.C.

ORP 2005. Hanford Integrated Disposal Facility Performance Assessment: 2005 Version, ORP-25439, Revision 0, Department of Energy - Office of River Protection, Richland, Washington. September 2005.

Peggs, I. D. 2003. Geomembrane Liner Durability: Contributing Factors and the Status Quo, I-CORP International, Inc., http://geosynthetica.net/tech_docs/IDPigsUKpaper.pdf, June 2010.

Phifer, M. A. 1991. Closure of a Mixed Waste Landfill - Lessons Learned. Waste Management 1991, Tuscon, AZ. Pp. 517-525. 
Phifer, M. A., Drumm, E. C., and Wilson, G. V. 1993. Effects of Post Compaction Water Content Variation on Saturated Conductivity. Hydraulic Conductivity and Waste Contaminant Transport in Soils, ASTM STP 1142, D. E. Daniel and S. J. Trautwein, Eds., American Society for Testing and Materials, Philadelphia.

Phifer, M. A., Boles, D. R., Drumm, E. C., and Wilson, G. V. 1995. Comparative Response of Two Barrier Soils to Post compaction Water Content Variations. Geoenvironment 2000: Characterization, Containment, Remediation, and Performance in Environmental Geotechnics, New Orleans, LA. February 22-24, 1995.

Phifer, M. A. and Nelson, E. A. 2003. Saltstone Disposal Facility Closure Cap Configuration and Degradation Base Case: Institutional Control to Pine Forest Scenario (U), WSRC-TR-2003-00436, Westinghouse Savannah River Company, Aiken, SC.

Phifer, M. A., Jones, W. E., Nelson, E. A., Denham, M. E., Lewis, M. R., and Shine, E. P. 2007. FTF Closure Cap Concept and Infiltration Estimates, WSRC-STI-2007-00184 OUO, Revision 2, Savannah River National Laboratory, Aiken, SC. October 2007.

Powell, J., R. Abitz, K. Broberg, W. Hertel, and F. Johnston 2011b, Status and Performance of the OnSite Disposal Facility Fernald Preserve, Proceedings of Waste Management 2011, February 27-March 3, 2011, Phoenix, AZ.

Powell, J., V. Kothari, B. Cato, Y. Deyo, R. Thompson, and T. Uhlmeyer 2011a, Weldon Spring Disposal Cell Performance: The First Ten Years, Proceedings of Waste Management 2011, February 27-March 3, 2011, Phoenix, AZ.

Rowe, R.K., Rimal, S. and Sangam, H.P. 2002. Durability of HDPE geomembranes. Geotextiles and Geomembranes, Vol. 20, pp. 77-95.

Rowe, R.K., Rimal, S. and Sangam, H.P. 2009. Ageing of HDPE geomembrane exposed to air, water and leachate at different temperatures. Geotextiles and Geomembranes, Vol. 27, No. 2, pp. 137-151.

Schroeder, P. R., Lloyd, C. M., Zappi, P. A., and Aziz, N. M. 1994a. The Hydrologic Evaluation of Landfill Performance (HELP) Model User's Guide for Version 3. EPA/600/R-94/168a. Office of Research and Development, United States Environmental Protection Agency (EPA), Cincinnati, Ohio. September 1994.

Schroeder, P. R., Dozier, T. S., Zappi, P. A., McEnroe, B. M., Sjostrom, J. W., and Peyton, R. L. 1994b. The Hydrologic Evaluation of Landfill Performance (HELP) Engineering Documentation for Version 3. EPA/600/R-94/168b. Office of Research and Development, United States Environmental Protection Agency (EPA), Cincinnati, Ohio. September 1994.

Serrato M. G. 2007. GeoTesting Express unpublished data sheets. Washington Savannah River Company, Aiken, SC. October 3, 2006.

Shott, G. J., Barker, L. E., Rawlinson, S. E., Sully, M. J., and Moore, B. A. 1998. Performance Assessment for the Area 5 Radioactive Waste Management Site at the Nevada Test Site, Nye County, Nevada (Rev. 2.1), DOE/NV/11718-176, UC-721, Bechtel Nevada. January 1998.

SRR 2009. Performance Assessment for the Saltstone Disposal Facility at the Savannah River Site, SRRCWDA-2009-00017, Rev. 0, Savannah River Remediation LLC, Aiken, SC. October 2009. 
SRR 2010. Performance Assessment for the F-Area Tank Farm at the Savannah River Site, SRS-REG2007-00002, Rev. 1, Savannah River Remediation LLC, Aiken, SC. March 31, 2010.

SRR 2012. Performance Assessment for the H-Area Tank Farm at the Savannah River Site, SRR-CWDA2010-00128, Rev. 1, Savannah River Remediation LLC, Aiken, SC. November 2012.

Taha, O. M. E. and Taha, M. R. 2011. Cracks in Soils Related to Desiccation and Treatment. Australian Journal of Basic and Applied Sciences, Vol. 5, No. 8, pp. 1080-1089.

Whyatt, G. A. and Farnsworth, R. K. 1990. The High pH Chemical and Radiation Compatibility of Various Liner Materials. Geosynthetic Testing for Waste Containment Applications. Koerner, R. M. (editor). STP 1081, pp110-124. American Society of Testing and Materials, Philadelphia, PA.

WCH 2013. Performance Assessment for the Environmental Restoration Disposal Facility, Hanford Site, Washington, WCH-520, Rev. 0, Washington Closure Hanford, Hanford, WA. March 2013.

WCS 2007. Application for License to Authorize Near-Surface Land Disposal of Low-Level Radioactive Waste, Appendix 8.0-7: Sensitivity and Uncertainty Analysis, Rev. 12a, March 16, 2007, Waste Control Specialists LLC, Three Lincoln Center, 5430 LBJ Freeway, Suite 1700, Dallas TX 75240.

Witt, K. J. and Siegmund, M. 2001. Laboratory Testing of GCL under Changing Humidity. Proceedings of the $8^{\text {th }}$ International waste Management and Landfill Symposium, Sardinia Second Conference, Euro Waste, Sardinia 2001.

WSRC 2008. E-Area Low-Level Waste Facility DOE 435.1 Performance Assessment, WSRC-STI-200700306, Rev. 0, Washington Savannah River Company, Aiken, SC. July 2008. 
SRNL-STI-2014-00409

Revision 0

Appendix A. Original White Paper on Consideration of Long-Term Performance of Barriers (Covers and Liners) in a Performance Assessment 


\section{CONSIDERATION OF LONG-TERM PERFORMANCE OF BARRIERS (COVERS AND LINERS) IN A PERFORMANCE ASSESSMENT}

Covers and liners serve significantly different roles in disposal cells. Covers are designed to reduce the rate at which water infiltrates into the disposal facility and may also be designed to serve as a deterrent to biotic and inadvertent human intrusion. Liners can be used as part of a facility design to collect water that migrates through a waste disposal cell, so it can be captured in the leachate collection system. Liner performance is primarily oriented towards operations when the facility is exposed to precipitation and large quantities of water may be introduced for compaction and dust suppression. Liners also play a role after a cover is put in place to collect any drainage of excess moisture remaining in the waste after operations, while the leachate collection system is maintained. Cover performance is important after closure of the facility, especially during the time after the leachate collection system ceases to be maintained. Covers are intended to be placed over the disposed waste and actively maintained for some period of time and then expected to continue to limit infiltration for an additional period of time without maintenance. The length of time that covers will continue to be effective will depend on local conditions, potential for subsidence, and the complexity of the cover required.

Due to large uncertainties in long-term performance, it has proven to be a challenge to determine specifically how long a liner, if present, or cover can be expected to perform and the timing of changes in the rate at which water can flow through these barriers. The relative timing can be important in the context of the 1,000 year compliance period. There is potential for accumulation of water above a liner when leachate collection ceases, if infiltration through the cover is greater than the storage capacity of the waste and leakage through the liner. This can lead to the potential for a bathtub or slug of early radionuclide release as the liner begins to fail. For the cover, the significant considerations are how long the cover is likely to continue to limit infiltration and whether it has been designed in such a way as to deter biotic and inadvertent human intrusion. Thus, it is generally suggested to address a range of potential failure scenarios to understand the significance of assumptions regarding the performance of different layers. Considerations for developing a set of conditions to be evaluated are provided below.

\section{Regulatory Considerations}

- It is suggested that the approach to addressing long-term performance of covers and liners in a performance assessment be determined on a case-by-case basis through negotiation with the appropriate regulators, typically EPA and the State regulator. This is appropriate because each liner and cover is designed individually to address the climate, hydrogeology, and current technical standards at the time of construction.

- While reference to the negotiated credit applied to other facilities may be made, the inherent uncertainties associated with site and facility specific effects on long term performance must be recognized. Likewise, it must be realized that the knowledge base to support assumptions regarding liner and cover performance increases with time and that different regulators approach the issue with different interests and concerns.

- Early discussions with the regulator should seek to understand specific concerns and interests relative to long term performance. The role of the time of compliance and the level of regulator technical awareness relative to the long-term performance of covers and liners should be established early on in the negotiations. These essentially form the base-line from which the negotiations will proceed.

- Care must be taken to clearly identify assumptions believed to over predict consequences (e.g., higher infiltration rate through a cover than expected, early failure of liners) and to place any negotiated scenarios in context of how the scenarios relate to performance that would typically be expected. This documentation can be used to support other cases where it is desirable to reduce the level of conservatism applied for a given assumption. 
Use of a Systems Approach

- A systems approach should be used when developing the assumptions regarding cover and liner performance. The long-term performance of covers is defined in terms of infiltration into the waste zone and of liners is defined in terms of leakage out of the disposal facility into the environment. A systems approach considers the functionality of each cover and liner layer and the composite effect of all cover and liner layers on peak releases over time. Initially, this information can be described in a qualitative manner to help understand the roles of different layers in terms of performance, but quantitative values will need to eventually be defined.

- Consideration should be given to providing information that provides a reasonable range of infiltration through covers and leakage through liners and the range of times over which changes in rates can occur. Given that it is not possible to predict the exact timing of changes, it is most pragmatic to consider a range of assumptions to address the uncertainty. Also, over the long-term, background infiltration estimates can help place bounds on cover failure in cases where significant waste subsidence is not anticipated.

\section{Technical Factors}

- Significant advancement in knowledge associated with the longevity of individual barrier materials, particularly high density polyethylene (HDPE) geomembranes, compacted clay layers (CCL), and geosynthetic clay liners (GCL), has been made over the past 30 years. Consideration should be given to the production of "white papers" for the regulators which discuss the state of knowledge concerning the individual barrier material longevity and the combined longevity associated with the use of composite barriers (i.e. use of multiple barriers together). Such "white papers” should include a discussion of degradation mechanisms and their applicability to the landfill location and design.

- Less information is available regarding the longevity of drainage layers, either natural sand/gravel or geonets. The primary concern associated with natural sand/gravel drainage layers is the potential for pluggage (geochemical, biological, siltation, root, etc.). The primary concern associated with geonets is the longevity of the associated filter fabric.

- The longevity of covers and liners may differ due to different degradation mechanisms associated with each. Covers may be subject to such degradation mechanisms as erosion, root penetration, burrowing animals, desiccation, and waste subsidence to which liners are generally not subject. Liners may be subject to degradation from waste leachate contact. There is a possibility that liners may degrade after covers, and therefore concerns of the possibility of a bath tub effect where radionuclides leach out of the waste and pool up at a low point of the liner with a sudden release once the liner has been breached. Some have suggested that prior to emplacement of the cover or when ending operation of the leachate collection system, that the liner be punctured in several locations to limit the potential for pooling. 
SRNL-STI-2014-00409

Revision 0

Intentionally Blank 
SRNL-STI-2014-00409

Revision 0

Appendix B. High Energy Irradiation Degradation of HDPE Geomembranes 


\section{HIGH ENERGY IRRADIATION DEGRADATION OF HDPE GEOMEMBRANES}

High density polyethylene (HDPE) degradation by high energy irradiation can be similar to degradation by ultraviolet (UV) radiation (Needham et al. 2004). It has often been cited that the basic mechanical properties of a typical polymer start to change due to irradiation degradation by main chain scission at a total dose greater than 1 to 10 Mrad (Phillips 1988; Koerner et al., 1990; Koerner 1998; Nimitz et al. 2001; Needham et al., 2004). However, as discussed below, the impact of irradiation on polymers, and on HDPE in particular, is determined primarily by the total absorbed dose and the presence or absence of oxygen.

The absorption of high energy ionizing radiation such as gamma rays ( $\gamma$-rays) by polymers primarily results in the production of free cation radicals and the ejection of electrons within the polymer. The ejected electrons can induce additional ionizations or produce electronic excitation in surrounding molecules. Secondary reactions can include the production of ions (both cations and anions) and free anion radicals. These products of radiation absorption are unstable and are reactive toward surrounding intact molecules resulting in both crosslinking (combining polymer molecules) and main-chain scission (breakage of polymer molecules). For polyethylene the extent of irradiation induced crosslinking or main chain scission appears to be independent of the type of radiation within a factor of 2 (i.e., alpha particles, beta particles, gamma-rays, X-rays, protons). Crosslinking predominates in the absence of oxygen and main chain scission predominates in the presence of oxygen. (Schnabel 1981; Sangster 1993; Harper 1996; Kudoh et al. 1996)

Irradiation of polyethylene in the absence of oxygen at relatively low doses (i.e. less than $10 \mathrm{Mrad}$ ) primarily results in crosslinking, which improves temperature and chemical resistance, increases the elastic modulus, tensile strength, and hardness, reduces the solubility, and improves the weatherability of the polyethylene (Kresser 1957; Frados 1976; Schnabel 1981; Sangster 1993). However, at high absorbed doses polyethylene becomes very hard and brittle (Kresser 1957; Kane and Widmayer 1989; Sangster 1993). For high density polyethylene (HDPE) the ultimate strength half-dose value in vacuum has been measured at greater than 5000 Mrad and the ultimate elongation half-dose value in vacuum has been measured at between 10 to 30 Mrad (Brandrup and Immergut 1989). The half-dose value is the absorbed dose required to reduce a particular mechanical property of the polymer by half under a defined environment (Brandrup and Immergut 1989). (Schnabel 1981)

However during irradiation in the presence of oxygen (i.e., in the presence of air) polyethylene undergoes predominately main-chain scission, which results in a rapid deterioration and subsequent deleterious impact upon mechanical properties. Main-chain scission can occur during reactions involving peroxyl and oxyl radicals. Since the oxidation of free cation radicals, produced during irradiation, results in peroxyl and oxyl radicals, the presence of oxygen during irradiation results in the occurrence of more main-chain scission. Additionally oxygen can react with lateral macroradicals, which would otherwise crosslink, thus reducing the occurrence of crosslinking. Finally radiation can provide the activation energy necessary for oxidation to occur, if oxygen is available. (Schnabel 1981; Sangster 1993; Sun et al. 1996; BaduTweneboah et al. 1999)

In the absence of oxygen the dose rate does not appear to influence the impact of irradiation on polyethylene (Brandrup et al. 1999). However in the presence of oxygen the following are two apparent dose rate effects (Schnabel 1981; Brandrup and Immergut 1989):

- High dose rates can result in the rapid depletion of oxygen within a polymer. This can result in further polymer deterioration, due to the combined effect of irradiation and oxidation which produces main-chain scission, being limited by oxygen diffusion into the polymer. In the case of polyethylene this can actually lead to increased crosslinking due to further irradiation once the 
interior oxygen has been depleted and an actual improvement in mechanical properties. In this case main-chain scission only occurs at the surface of the polymer where oxygen is available. This, therefore, produces an apparent dose rate effect upon polymer deterioration at high dose rates. (Brandrup et al. 1999). At low dose rates polymer deterioration due to main-chain scission produced by irradiation and oxidation is not limited by oxygen diffusion into the polymer. Therefore at these low dose rates the full impact of combined irradiation and oxidation is realized. Therefore at lower dose rates, dose rate does not appear to impact degradation due to irradiation but it appears to be dependent upon total dose and the presence of oxygen. Polymer thickness also impacts the influence of oxygen on the polymer, because the thicker the polymer the longer the diffusion path for oxygen diffusion into the polymer (Brandrup et al. 1999). Figure B-1 and Table B-1 provide the impact of dose rate on the half-dose values for ultimate strength and ultimate elongation of HDPE in air (Brandrup and Immergut 1989). From Figure B-1 it is seen that dose rates above about $5000 \mathrm{Rad} / \mathrm{hr}$ have an apparent dose rate effect while dose rates below 5000 $\mathrm{Rad} / \mathrm{hr}$ do not.

- High dose rates can also result in an increase in the polymer's temperature. Many chemical reactions have fairly high activation energies, which can be overcome with the irradiation induced temperature increase and lead to reactions which might not otherwise occur (Brandrup et al. 1999).

Mechanical stress combined with irradiation is also known to accelerate radiation-induced degradation. (Hamilton et al. 1996).

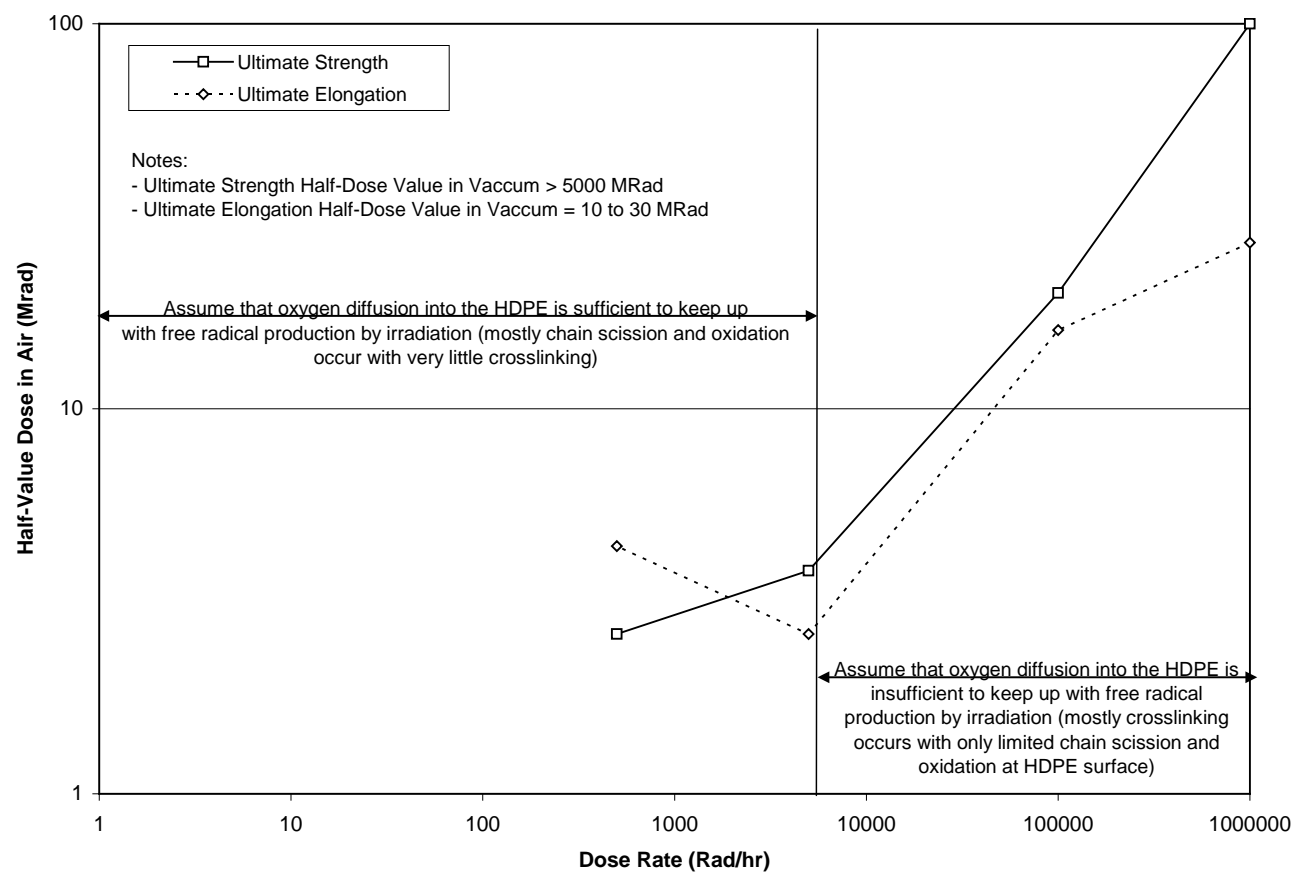

Figure B-1. Dose Rate Impact on HDPE Ultimate Strength and Elongation Half-Value Dose in Air (Brandrup and Immergut 1989). 
Table B-1. Dose Rate Impact on HDPE Ultimate Strength and Elongation Half-Value Dose in Air (Brandrup and Immergut 1989).

\begin{tabular}{|l|l|l|}
\hline $\begin{array}{c}\text { Dose Rate } \\
\text { (Rad/hr) }\end{array}$ & $\begin{array}{c}\text { Ultimate Strength } \\
\text { Half-Value Dose in } \\
\text { Air } \\
\text { (Mrad) }\end{array}$ & $\begin{array}{c}\text { Ultimate Elongation } \\
\text { Half-Value Dose in } \\
\text { Air } \\
\text { (Mrad) }\end{array}$ \\
\hline 1000000 & 100 & 27 \\
\hline 100000 & 20 & 16 \\
\hline 5000 & 3.8 & 2.6 \\
\hline 500 & 2.6 & 4.4 \\
\hline
\end{tabular}

Mitigating Irradiation Impacts on HDPE

The impacts of irradiation on HDPE can be mitigated by one or a combination of the following:

- The radiation dose rate can be lowered through the use of shielding to reduce the total dose absorbed by the HDPE over the period of concern,

- The level of oxygen to which the HDPE is exposed over the period of concern can be lowered so that the level and rate of degradation is oxygen dependent,

- Antioxidants (prevents oxidative chain reactions and scavenges free radicals) and carbon black (acts as an energy sink ) can be incorporated into the HDPE to lower the impact of the presence of oxygen and radiation (Schnabel 1981; Brandrup et al. 1999),

- Thicker HDPE, such as $100 \mathrm{mil}(2.5 \mathrm{~mm})$ rather than $60 \mathrm{mil}(1.5 \mathrm{~mm})$, can be utilized to limit degradation to the surface of the sheet rather than to its interior, and/or

- Tensile stress on the HDPE can be minimized.

In most cases it is suggested that all of the mitigation means be employed.

Nuclear Regulatory Commission Recommendations

Staff from the Nuclear Regulatory Commission (NRC) recommended the following within Kane and Widmayer 1989:

"To compensate for the uncertainties associated with the long-term performance of geosynthetics, and to provide the level of confidence that is required by federal regulations, the use of geosynthetics alone (e.g., as a low-permeability geomembrane or as a geotextile filter fabric) is not recommended by the NRC staff. However, the use of geosynthetics to complement and improve the performance of natural soils and rocks or other proven construction materials is recommended by the staff.”

A "100 Mrad regulatory guideline was established to promote selection of polyethylene materials with extremely low risk of degradation under the exposure conditions expected in the high integrity containers." (Badu-Tweneboah et al. 1999) 


\section{HDPE Irradiation Examples}

Several HDPE irradiation examples are provided below particularly those dealing with its use in low-level radioactive waste disposal service:

- Whyatt and Fansworth (1990) evaluated a 60-mil HDPE geomembrane in simulated short-term (up to 120 days) chemical compatible tests with a high $\mathrm{pH}(\sim 14)$ inorganic solution at $90 \mathrm{oC}$ and subjected them to radiation doses ranging from 0.6 to 38.9 Mrad. The solution consisted predominately of the following in descending order: sodium, nitrite, nitrate, aluminum, potassium, and sulfate. With immersion in the solution and an applied radiation dose, the break strength and elongation decreased (i.e. properties degraded), while yield and puncture strengths and their associated elongations all increased (i.e., properties improved). The 38.9 dose was slightly greater than the break elongation half-dose value (the definition of the half-dose value is provided above) of the HDPE geomembrane under the conditions tested. No other properties tested were near the half-dose value.

- Badu-Tweneboah et al. 1999 performed an evaluation that demonstrated that the polyethylene components of a low-level radioactive waste disposal landfill in Barnwell South Carolina would perform their intended function of containment during at least the 500-year design period. The two polyethylene components were a 60 mil HDPE geomembrane in the cover system and 3/8 inch thick Linear Medium Density Polyethylene (LMDPE) inner liners within concrete high integrity containers for the disposal of low-level radioactive waste.

- Compatibility testing was performed on the 60-mil smooth HDPE geomembrane planned for the Hanford Grout facility. HDPE samples were exposed to a dose rate of 740,000 rads per hour until a total radiation dose of $16 \mathrm{Mrad}$ or $37 \mathrm{Mrad}$ was reached. The total dose of $37 \mathrm{Mrad}$ resulted in a greater than $25 \%$ decrease in geomembrane strength and elasticity. Then the HDPE was immersed in a $194^{\circ} \mathrm{F}$ solution with a $\mathrm{pH}$ of 9.2 and a concentration of inorganics of 368,336 mg/L. It was stated that under these conditions the HDPE showed no unacceptable effects. (INEEL 2004)

- $\quad$ Traditional radiation sterilization of polymers for medical implants is performed to a dose of 2.5 Mrad (Deng et al. 1996).

\section{Summary}

If the dose rate is below the $5000 \mathrm{Rad} / \mathrm{hr}$ dose rate above which an apparent dose rate effect in HDPE is seen, the irradiation impact upon a HDPE geomembrane can be assumed to be due to only total dose and not dose rate. From Table B-1 the HDPE ultimate strength half-value dose in air at a dose rate of 500 $\mathrm{Rad} / \mathrm{hr}$ was $2.6 \mathrm{Mrad}$ (Brandrup and Immergut 1989). The basic mechanical properties of a typical polymer start to change due to irradiation degradation at a total dose greater than 1 to 10 Mrad (Phillips 1988; Koerner et al., 1990; Koerner 1998; Nimitz et al. 2001; Needham et al., 2004), with levels as high as $100 \mathrm{Mrad}$ being listed as acceptable (Badu-Tweneboah et al. 1999). Therefore a total dose of $2.6 \mathrm{Mrad}$ appears to be a reasonable limit for total dose to HDPE geomembranes without significant impact.

\section{References}

Badu-Tweneboah, K., Tisinger, L.G., Giroud, J. P., Smith, B. S., 1999. Assessment of the Long-Term Performance of Polyethylene Geomembrane and Containers in a Low-Level Radioactive Waste Disposal Landfill, Geosynthetics '99 Conference Proceedings, Vol. 2, pp. 1055-1070, Industrial Fabrics Association International, Roseville, MN, 55113. 
Brandrup and Immergut (1989). Polymer Handbook, 3th edition, Brandrup, J., and Immergut, E. H. (editors). John Wiley \& Sons, Inc., New York.

Brandrup et al. (1999). Polymer Handbook, 4th edition, Brandrup, J., Immergut, E. H., and Grulke, E. A. (editors). John Wiley \& Sons, Inc., New York.

Deng et al. (1996). Effects of Gamma-ray Irradiation on Thermal and Tensile Properties of UltrahighMolecular-Weight Polyethylene Systems. Deng, M., Johnson, R. A., Latour, Jr., R. A., Shalaby, S. W. Irradiation of Polymers - Fundamentals and Technological Applications. Clough R. L. and Shalaby, S. W. (editors). ACS Symposium Series 620, pp 293-301. American Chemical Society, Washington, DC.

Frados (1976). Plastics Engineering Handbook of the Society of the Plastics Industry, Inc., 4th edition, Frados, J. (ed.). Van Nostrand Reinhold Company, New York.

Hamilton et al. (1996). Anisotropic Properties in Ultrahigh-Molecular-Weight Polyethylene after Cobalt60 Irradiation. Hamilton, J. V., Greer, K. W., Ostiguy, P., and Pai, P. N. Irradiation of Polymers Fundamentals and Technological Applications. Clough R. L. and Shalaby, S. W. (editors). ACS Symposium Series 620, pp 81-93. American Chemical Society, Washington, DC.

Harper (1996). Handbook of Plastics, Elastomers, and Composites, 3rd edition, Harper, C. A. (ed.). McGraw-Hill, New York.

INEEL 2004. Engineering Design File Project No. 23350 Liner/Leachate Compatibility Study. EDF-ER278, Revision 2, Idaho National Engineering and Environmental Laboratory (INEEL), 6/18/04.

INEEL 2005. Engineering Design File project NO. 23350 Liner/Leachate Compatibility Study, EDF-ER278, Revision 3, Idaho National Engineering and Environmental Laboratory (INEEL), 01/11/05

Kane and Widmayer (1989). Consideration for the Long-Term Performance of Geosynthetics at Radioactive Waste Disposal Facilities. Durability and Aging of Geosynthetics, ed. R. M. Koerner, London: Elsevier, 1989, pp. 13-27.

Koerner et al. (1990). Long-Term Durability and Aging of Geomembranes. Koerner, R. M., Halse, Y. H., and Lord, Jr., A. E. Waste Containment Systems: Construction, Regulation, and Performance, Bonaparte R. (editor), Geotechnical Special Publication No. 26, American Society of Civil Engineers, San Francisco, CA. pp. 106-134.

Koerner, R. M. 1998. Designing with Geosythetics, 4th edition. Prentice Hall, Upper Saddle River, New Jersey.

Kresser (1957). Reinhold Plastics Application Series 1. Polyethylene. Kresser, T. O. J. Reinhold Publishing Corporation, New York.

Kudoh et al. (1996). High-Energy Ion Irradiation Effects on Polymer Materials. Kudoh, H., Sasuga, T., and Seguchi, T. Irradiation of Polymers - Fundamentals and Technological Applications. Clough R. L. and Shalaby, S. W. (editors). ACS Symposium Series 620, pp 2-10. American Chemical Society, Washington, DC.

Needham et al. (2004). The likely medium to long-term generation of defects in geomembrane liners. Needham, A., Gallagher, E., Peggs, I., Howe, G, and Norris, J. R\&D Technical Report P1-500/1/TR, Environment Agency, Bristol, England. 
Nimitz et al. (2001). Chemical Compatibility Testing Final Report Including Test Plan and Procedures. Nimitz, J. S., Allred, R. E., and Gordon, B. W. SAND2001-1988, Sandia National Laboratories.

Phillips (1988). Effects of Radiation on Polymers. Phillips, D. C. Materials Science and Technology, Vol. 4, pp. 85-91.

Sangster (1993). Applications of Radiation Treatment of Ultradrawn Polyethylene. Sangster, D. F. Irradiation of Polymeric Materials - Processes, Mechanisms, and Applications. Reichmanis, E., Frank, C. W., and O’Donnell, J. H. (editors). ACS Symposium Series 527, pp 95-101. American Chemical Society, Washington, DC.

Schnabel (1981). Polymer Degradation Principles and Practical Applications. Schnabel, W. Hanser International, Germany (distributed by Macmillan Publishing Co., Inc., New York)

Sun et al. (1996). Development of an Accelerated Aging Method for Evaluation of Long-Term Irradiation Effects on Ultrahigh-Molecular-Weight Polyethylene Implants. Sun, D. C., Stark, C., and Dumbleton, J. H. Irradiation of Polymers - Fundamentals and Technological Applications. Clough R. L. and Shalaby, S. W. (editors). ACS Symposium Series 620, pp 340-349. American Chemical Society, Washington, DC.

Whyatt and Fansworth (1990). The High pH Chemical and Radiation Compatibility of Various Liner Materials. Whyatt, G. A. and Farnsworth, R. K. Geosynthetic Testing for Waste Containment Applications. Koerner, R. M. (editor). STP 1081, pp110-124. American Society of Testing and Materials, Philadelphia, PA. 


\section{Distribution:}

R. A. Aylward, 773-43A

B. T. Butcher, 773-43A

D. A. Crowley, 773-43A

G. P. Flach, 773-42A

L. L. Hamm, 703-41A

R. A. Hiergesell, 773-43A

G. K. Humphries, 730-4B

D. I. Kaplan, 773-43A

D. Li, 773-42A

M. A. Phifer, 773-42A

K. A. Roberts, 773-43A

R. R. Seitz, 773-43A

F. G. Smith, III 703-41A

G. A. Taylor, 773-43A 